\title{
Germany: Financial Sector Assessment Program-Detailed Assessment of Observance of IOSCO Objectives and Principles of Securities Regulations
}

This Report on the Detailed Assessment of Observance on IOSCO Objectives and Principles of Securities Regulations for Germany was prepared by a staff team of the International Monetary Fund as background documentation for the periodic consultation with the member country. It is based on the information available at the time it was completed in July, 2011. The views expressed in this document are those of the staff team and do not necessarily reflect the views of the government of Germany or the Executive Board of the IMF.

The policy of publication of staff reports and other documents by the IMF allows for the deletion of market-sensitive information.

Copies of this report are available to the public from

International Monetary Fund • Publication Services $70019^{\text {th }}$ Street, N.W. • Washington, D.C. 20431

Telephone: (202) 623-7430 • Telefax: (202) 623-7201

E-mail: publications@imf.org Internet: http://www.imf.org

\section{International Monetary Fund Washington, D.C.}


FinANCIAL SECTOR ASSESSMENT PROGRAM UPDATE GERMANY

\section{IOSCO OBJECTIVES AND PRINCIPLES OF SECURITIES}

REGULATION

DETAILED ASSESSMENT OF OBSERVANCE

JULY 2011

INTERNATIONAL MONETARY FUND

MONETARY AND CAPITAL MARKETS DEPARTMENT 


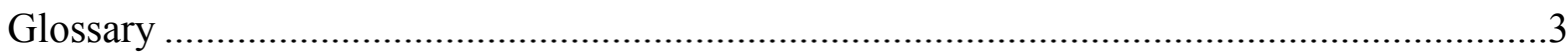

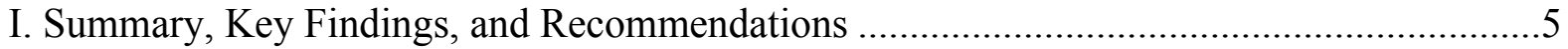

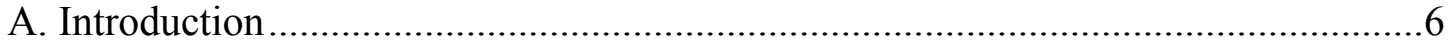

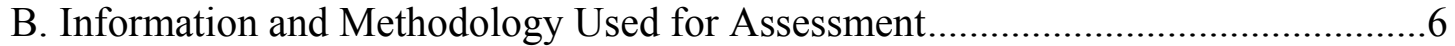

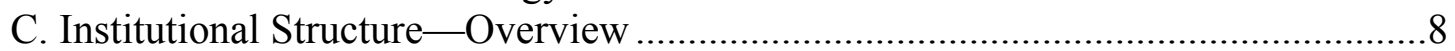

D. Market Structure and Activity...................................................................

E. Exchange and Other Regulated Markets (MTFs) ............................................. 10

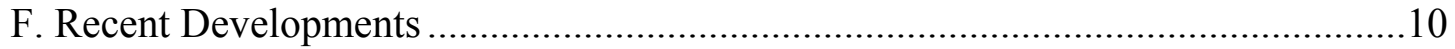

G. Preconditions for Effective Securities Regulation ..............................................11

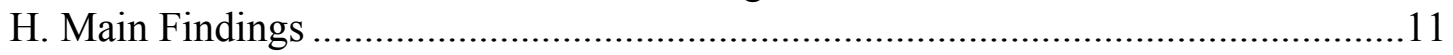

I. Recommended Action Plan and Authorities' Response .....................................22

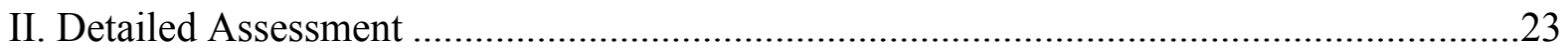

Tables

1. Summary Implementation of the IOSCO Principles - ROSCs .......................................14

2. Recommended Action Plan to Improve Compliance with the IOSCO Objectives and

Principles for Securities Regulation......................................................................22

3. Detailed Assessment of Implementation of the IOSCO Principles ..................................23

Appendixes

1. New IOSCO Principles 


\section{GLOSSARY}

$\begin{array}{ll}\text { AktG } & \text { Stock Corporation Act (Aktiengesetz) } \\ \text { AOC } & \begin{array}{l}\text { Auditor Oversight Commission } \\ \text { (Abschlussprüferaufsichtskommission-APAK) }\end{array} \\ \text { BaFin } & \begin{array}{l}\text { German Federal Financial Supervisory Authority } \\ \text { (Bundesanstalt für Finanzdienstleistungsaufsicht) }\end{array} \\ \text { BörsG } & \text { Exchange Act (Börsengesetz) } \\ \text { BMF } & \text { Federal Ministry of Finance (Bundesministerium der Finanzen) } \\ \text { BörsG } & \text { Exchange Act (Börsengesetz) } \\ \text { BörsO } & \text { Exchange Rules (Börsenordnung) } \\ \text { Bundesbank } & \text { Deutsche Bundesbank } \\ \text { CRA } & \text { Credit Rating Agency } \\ \text { DepotG } & \text { Custody Act (Depotgesetz) } \\ \text { DerivateV } & \text { Ordinance on Derivatives (Verordnung über Risikomanagement und } \\ & \text { Risikomessung beim Einsatz von Derivaten in Sondervermögen nach } \\ & \text { dem Investmentgesetz-Derivateverordnung) } \\ \text { DPR } & \text { Financial Reporting Enforcement Panel (FREP) } \\ & \text { (Deutsche Prüfstelle für Rechnungslegung) } \\ \text { DRSC } & \text { German Accounting Standards Committee (GASC) } \\ & \text { (DeutschesRechnungslegungs Standards Committee) } \\ \text { DSR } & \text { German Accounting Standards Board (GASB) } \\ & \text { (Deutscher Standardisierungsrat) } \\ \text { EAEG } & \text { Deposit Guarantee and Investor Compensation Act } \\ & \text { (Einlagensicherungs- und Anlegerentschadigungsgesetz) } \\ \text { EdW } & \text { Compensation Fund of Securities Trading Companies } \\ & \text { (Entschädigungseinrichtung der Wertpapierhandelsunternehmen) } \\ \text { ESA } & \text { Exchange Supervisory Authority (Börsenaufsichtsbehörde) } \\ \text { ESMA } & \text { European Securities Markets Authority } \\ \text { FinDAG } & \text { Finanzdienstleistungsaufsichtsgesetz } \\ \text { FSAP } & \text { Financial Stability Assessment Program } \\ \text { GwG } & \text { Anti Money Laundering Act (Geldwaschegesetz) } \\ \text { HGB } & \text { Commercial Code (Handelsgesetzbuch) } \\ \text { IDW } & \text { Institute of German Certified Public Accountants } \\ & \text { (Institut derivative Wirtschaftsprüfer in Deutschland e.V.) } \\ \text { IFRS } & \text { International Financial Reporting Standards } \\ \text { InhKontrollV } & \text { Inhaberkontroll verordnung } \\ \text { IOSCO } & \text { International Organization of Securities Commissions } \\ \text { ISA } & \text { International Standards on Auditing } \\ \text { KAGG } & \text { Investment Companies Act (Gesetz über Kapitalanlagegesellschaften) } \\ \text { KWG } & \text { German Banking Act (Kreditwesengesetz) } \\ \text { MaComp } & \text { Minimum Requirements for Compliance (Mindestanforderungen an die } \\ & \end{array}$


Compliance-Funktion und die weiteren Verhaltens-,Organisations- und Transparenzpflichten nach $\S \S 31 \mathrm{ff}$. WpHG für

Wertpapierdienstleistungsunternehmen

MaRisk Minimum Requirements for Risk Management (Mindestandforderungen an das Risikomanagement)

MTF Multilateral Trading Facility

SolvV Solvency Ordinance (Solvabilitätsverordnung)

TSO Trading Surveillance Office ( Handelsüberwachungsstelle - HÜSt)

UCITS Undertakings for Collective Investment in Transferable Securities

VerkProspG Act on the Prospectus for Securities Offered for Sale

(Verkaufsprospektgesetz)

VermVerkProspV Investment Prospectus Ordinance

(Vermögensanlagen-Verkaufsprospektverordnung)

WpHG Securities Trading Act (Wertpapierhandelsgesetz)

WPK Chamber of Auditors (Wirtschaftsprüferkammer)

WPO Public Auditors' Act (Gesetz über eine Berufsordnung der WirtschaftsprüferWirtschaftsprüferordnung)

WpPG Securities Prospectus Act (Wertpapierprospektgesetz)

WpÜG Securities Acquisition and Takeover Act

(Wertpapiererwerbs- und Übernahmegesetz) 


\section{SUMMARY, KEY FINDINGS, AND RECOMMENDATIONS}

1. Germany has a comprehensive legislative and institutional framework for the effective supervision of the securities markets. The German Federal Financial Supervisory Authority (Bundesanstalt für Finanzdienstleistungsaufsicht) (BaFin) and the State-based Exchange Supervisory Authorities (ESAs) appear operationally independent (though in the case of ESAs not in formal terms), and have sufficient resources to fulfill their regulatory functions.

2. The overall level of compliance with the International Organization of Securities Commissions (IOSCO) Principles is high, with many principles being fully

implemented. Two main factors influence the ability of the system to meet the highest standards required by the IOSCO Principles. First, the continued existence of "grey market" activity outside the fully regulated market means that functionally similar financial market products and activities are not subject to the same standard of regulation (this issue is of concern mainly regarding certain closed-end funds and retail-oriented products with embedded options, where regulations on potential mis-selling and services to retail investors are relatively light). The authorities are working on proposals to deal with this issue, and that initiative is to be encouraged. Second, in its supervision activities, BaFin relies heavily on the analysis of incoming reports and other data, including annual compliance reports on regulated entities prepared by external auditors. It makes comparatively little use of on-site compliance inspections, whether on a routine basis or as part of a program that identifies potential emerging compliance risks resulting from changes in market conditions or behavior. This affects compliance with a number of the IOSCO Principles. In addition, post trade transparency for trading on equities markets - while fully compliant with standards required under the European regime - applies only at the level of the individual market and does not result in an overall level of transparency because of the absence of standards for consolidating and disseminating post trade data. The authorities should work toward achieving a more complete "whole of market" transparency regime in the context of the current European-wide review of aspects of the Markets in Financial Instruments Directive (MiFID) regime.

3. There are significant industry concerns about the implementation costs resulting from a rapidly changing legislative framework, both in Europe as a whole and in Germany. In particular, concerns focus on differences in the timing of implementation between Germany and other States in Europe, and on material differences between the standards set in some German legislation and those required by European directives. This has potential impacts on compliance costs and competitiveness, for German-based firms active in the broader European market. 


\section{A. Introduction}

4. This assessment was carried out as part of the Financial Sector Assessment Program (FSAP) Update mission to Germany that took place between January 19 and February 4, 2011. ${ }^{1}$

\section{B. Information and Methodology Used for Assessment}

5. The assessor relied on a number of sources in carrying out this assessment, including: a review of the relevant legislation, the self-assessment prepared by the staff of BaFin, other material published by BaFin, detailed discussions with the staff of BaFin and other regulatory authorities and ministries, and discussions with a range of market participants and representative bodies. The assessor extends his thanks to the staff of the authorities for their cooperative participation in the process and for their comprehensive selfassessment.

6. The assessor extends his thanks to the staff of the authorities for their participation in the process and for their comprehensive self assessment. Staff of BaFin was particularly generous in making themselves available for discussions that were helpful and frank, and in providing requested information and copies of the relevant legislative or regulatory texts. Staffs of Federal ministries were similarly helpful. The assessor also values the assistance and information provided by other regulators and market participants.

7. The assessment was conducted based on the IOSCO Objectives and Principles of Securities Regulation and the associated methodology adopted in 2003, as updated in 2008. ${ }^{2}$ An assessment of the securities settlement systems under the Committee on Payment and Settlement Systems (CPSS)/IOSCO Recommendations was conducted separately, so Principle 30 is not considered in this assessment.

8. During the assessment, the new principles adopted by IOSCO and published in June 2010 were also discussed. These new principles are not yet the subject of a formal methodology and discussions about them were informal and not part of the assessment. Nonetheless, this report reflects those discussions in Appendix 1.

9. The assessment of the country's observance of each individual principle is made by assigning to it one of the following assessment categories: fully implemented, broadly implemented, partly implemented, not implemented, and not applicable. The IOSCO assessment methodology provides a set of detailed criteria to be met in respect of each

\footnotetext{
${ }^{1}$ The assessment was undertaken by Malcolm Rodgers, former Executive Director and Acting Commissioner of the Australian Securities and Investments Commission.

2 The IOSCO methodology was amended in 2008 to update footnotes to reflect recent IOSCO publications. Currently IOSCO is expanding the methodology to cover the new principles adopted in mid 2010.
} 
principle to achieve the designated benchmarks. The methodology recognizes that the means of implementation may vary depending on the domestic context, structure, and stage of development of the country's capital market and acknowledges that regulatory authorities may implement the principles in many different ways.

- A principle is considered fully implemented when all assessment criteria specified for that principle are generally met without any significant deficiencies.

- A principle is considered broadly implemented when the exceptions to meeting the assessment criteria specified for that principle are limited to those specified under the broadly implemented benchmark for that principle and do not substantially affect the overall adequacy of the regulation that the principle is intended to address.

- A principle is considered partly implemented when the assessment criteria specified under the partly implemented benchmark for that principle are generally met without any significant deficiencies.

- A principle is considered not implemented when major shortcomings (as specified in the not implemented benchmark for that principle) are found in adhering to the assessment criteria specified for that principle.

- A principle is considered not applicable when it does not apply because of the nature of the country's securities market and relevant structural, legal and institutional considerations.

10. This is the second assessment of the German system against IOSCO Principles, with the first being conducted 2003. That assessment against IOSCO Objectives and Principles concluded that securities regulation in Germany is based on a well developed and comprehensive system of regulation and supervision, and has been implemented with appropriate institutional capacity. All but three principles were rated fully implemented, with one rated broadly implemented (Principle 1) and one (Principle 2) rated partly implemented; one principle (Principle 30) was not assessed. It should be noted that the first assessment was undertaken before IOSCO had finalized a detailed methodology for assessment. Since 2003, there have been continuous developments in the legislative framework both at the European level and the German national level since the original assessment in 2003. ${ }^{3}$

\footnotetext{
${ }^{3}$ For example, the Transparency and the Markets in Financial Instruments Directive (MiFID) directivesamong others - have come into effect since 2003. At the national level there have been numerous developments, including legislation - for example—-legislation restricting and imposing a transparency regime for short selling.
} 
11. The conclusions set out below are based on information and findings as of January 2011. The assessment takes place against a background of continuing change in the legislative framework and the regulatory environment for securities regulation.

\section{Institutional Structure-Overview}

12. Since Germany is a Federal Republic, lawmaking takes place at both the federal and States (Länder) levels. In addition, regulatory and governmental institutions exist at both levels too. Most laws governing the regulation of the financial market and services activity are federal, the exceptions mainly being subordinate legislation (Ordinances) made by the States relating to exchange markets. The States play a role in the regulation of exchange markets, and the State-based ESAs have responsibility for the authorization and direct supervision of exchange markets.

13. At the Federal level, BaFin is responsible for administering and enforcing the large body of different laws that govern capital and financial services market activity. Other Federal legislation not administered by BaFin — such as company legislation, legislation on public auditors, and competition legislation - has an impact on market activity and participants, and the overall regulatory environment for securities market activity.

14. Within BaFin, the Securities Directorate is responsible for most securities regulation activity including regulation of:

- capital market activity such as public securities issues, takeovers and issuers' disclosure and reporting obligations;

- $\quad$ collective investments;

- $\quad$ regulated markets other than exchange markets;

- $\quad$ compliance with prohibitions on insider trading and market manipulation; and

- $\quad$ investment services provided by market intermediaries.

15. Prudential supervision of banks that provide investment services is carried out by the BaFin's Banking Directorate, rather than its Securities Directorate.

16. Other authorities such as the Bundesbank and prosecutorial authorities-in cases such as criminal prosecution of market and other financial services offenceswork more directly with BaFin on a regular basis.

17. BaFin's overall structure and activities are governed by the legislation that created it, duties and powers created by the legislation it administers, and by legislation generally applying to government authorities generally, such as the Administrative Procedures Act and other public administration legislation. 
18. BaFin does not play an active role in regulatory rulemaking, in the sense of creating rules, which it can then enforce administratively against regulated entities. This is in line with the approach in Germany-based on fundamental constitutional principles - that limits the ability of regulatory authorities to make binding rules unless specific legislation expressly envisages this. In practice, BaFin's rule-making function is largely confined to making detailed, technical rules pursuant to primary or secondary legislation.

19. As elsewhere in the European Union (EU), the European regulatory framework ${ }^{4}$ plays a very significant role in the German national regulatory framework. Some parts of the European regulatory framework are translated into national law, and some parts apply directly of their own force. The reform agenda at the European level is significant, and includes reviews of some fundamental aspects of the regulation of market activity, such as MiFID. There is also a separate German domestic reform agenda, for example the recent legislation on short selling and proposals to deal with mis-selling in currently unregulated or lightly regulated markets.

20. In addition, the new European body for securities markets, the European Securities Market Authority (ESMA), commenced operations on January 1, 2011. It will have policy making functions, oversight responsibilities over national authorities, and supervisory responsibility over credit rating agencies (CRAs).

\section{These developments pose considerable challenges to regulators and market} participants alike. There are significant industry concerns about the implementation costs resulting from a rapidly changing legislative framework, both in Europe as a whole and in Germany. In particular, concerns focus on differences in the timing of implementation between Germany and other States in Europe; and on material differences between the standards set in some German legislation and those required by European directives. This has potential impacts on compliance costs, and competitiveness, for German-based firms active in the broader European market.

\section{Market Structure and Activity}

22. The German financial sector is dominated by banking institutions. Banks are the major players, including in asset management and securities and derivatives market activity.

\footnotetext{
${ }^{4}$ This framework includes directives covering prospectuses, transparency of information provided by issuers, markets in financial instruments, capital requirements, market abuse, takeovers, and collective investment schemes.
} 


\section{E. Exchange and Other Regulated Markets (MTFs)}

23. There are currently seven securities exchanges (Frankfurt, München, Berlin, Hamburg, Hannover, Düsseldorf, Stuttgart), one derivatives exchange (Eurex Deutschland in Frankfurt), and one energy exchange (EEX in Leipzig) approved by the regulatory authority in the relevant German States. There are two approved multilateral trading facilities (MTFs), although their activities predated the requirement for regulatory approval and no totally new MTF markets have commenced. The Frankfurt exchange dominates trading in equities, with well in excess of 90 percent of trading taking place on that exchange. The Stuttgart Stock Exchange has created a strong market in retail level trading of non-share instruments.

Financial services firms licensed by BaFin

24. At end-2010, there were 717 nonbank financial institutions licensed to provide investment services by BaFin, of which 521 were licensed to provide portfolio management services; around 800 banks also provide investment services under the licenses they hold as credit institutions.

\section{Capital market activity}

25. As at end-2010, 908 issuers have been admitted to trade on regulated markets. There were 65 initial public offerings (IPOs) in 2010 (down from 97 in 2008). Takeover activity has declined since the financial crisis, from a total of 39 in 2008 to 27 in 2010.

\section{Investment business}

26. At end-2010, there were 73 authorized asset management companies managing $\mathbf{5 , 9 9 7}$ funds with total assets under management of $€ 1,127$ billion, including 42 hedge funds and funds of hedge funds. Over 8,000 foreign investment funds were licensed to distribute in German, of which all but a relatively small number are Undertakings for Collective Investment in Transferable Securities (UCITS) funds. A very large number of financial products are traded on some German markets (for example, more than 500,000 products are available for trading on the Stuttgart market), of which 70 percent are structured products - "certificates" -25 percent are bonds and 5 percent shares or mutual fund exchange traded funds).

\section{F. Recent Developments}

27. The financial crisis and its aftermath have affected activity in the securities sector as well as other parts of the financial sector and the real economy. Two particular points of stress should be noted: 
- $\quad$ First, there has been considerable pressure on retail open-ended real estate funds, where a total of 48 regulated funds manage assets of almost $€ 87$ million, more than 25 percent of the total value of all domestic funds operating at the retail level.

Thirteen funds closed their redemption facility; 3 have made the decision to liquidate; and the remaining 10 must decide whether to reopen or liquidate in the near future.

- $\quad$ Second, the investor compensation fund established under the Deposit Guarantee and Investor Compensation Act (EAEG) came under funding pressure because of a single incident - potentially involving fraud - that resulted in a very large number of claims. These claims placed stress on the ongoing liquidity of the fund, resulting in special levies and reconsideration of the long-term basis for fund contributions.

\section{G. Preconditions for Effective Securities Regulation}

28. The general preconditions necessary for the regulation of securities markets appear to be in place in Germany. There is a stable macroeconomic environment. There are no significant barriers to entry and exit for market participants. Competition is encouraged and foreign participation is welcomed. The legal and accounting framework is sound. The German legal framework for the securities sector is complemented by comprehensive legislation for companies and for commercial activity generally. Commercial law has been kept modern and corporate governance standards have been recently reviewed.

\section{H. Main Findings}

\section{BaFin's overall approach to supervision relies very heavily on (i) the flow of} information coming to it from the regulated population; (ii) mandatory reports such as auditors' reports on regulated entities' financial condition; and (iii) compliance with legislative obligations. It has recently adopted a risk scoring methodology for the regulated population, but this is in its early stages and does not seem to have yet resulted in active monitoring programs calibrated on a risk basis. A new cross-divisional system of examining more systemic risks is in the process of being established.

30. Principles for the regulator (Principles 1-5): Regulators at both the Federal and State levels work with a clear legal framework and clearly defined powers and responsibilities. In practice, BaFin and the ESAs appear to be operationally independent. However, since the ESAs are within the State Ministries, formal preconditions of independence are not met. BaFin has a high level of accountability to the BMF, supported by documented arrangements for information flows from BaFin to the Ministry, but consideration should be given to streamlining its reporting obligations to the Ministry of Finance and mechanisms to enhance the security of tenure of its most senior management. Powers available to the regulators are sufficient for effective supervision of market activity. BaFin's funding arrangements and level of resources enable it to carry out regulatory mandate for securities markets. All authorities that play a role in regulation are treated as 
public bodies and subject to the framework for fairness and accountability that applies to such bodies, and their decisions can be challenged under administrative law processes. BaFin has adopted integrity policies that support their general obligations to maintain high standards of professional conduct. However, there remains significant "grey market" activity, where financial products (such as closed end funds, or participation rights) and services relating to them (especially marketing and advice) are subject to regulation at a lower standard that would be required under the IOSCO Principles. ${ }^{5}$

31. Principles for enforcement (Principles 8-10): BaFin (and where relevant, State regulated Trading Supervisory Offices and ESAs) have extensive powers to requisition documents and records and seek information from regulated entities and other persons. In addition, regulated entities have extensive reporting obligations and these reports provide a basis for review of compliance with legislative requirements. BaFin (and the State authorities) have power to take enforcement actions and sanction regulated entities (and other persons) for breaches, including by intervening in markets, issuing mandatory instructions to regulated entities and imposing monetary penalties. BaFin takes a systematic approach to ongoing supervision, based on report- and event-driven monitoring of the conduct of regulated entities and possible market abuse. It relies heavily on annual reports from external auditors relating to compliance systems and activities of regulated entities, and makes limited use of on-site inspections as a general tool to monitor entities' compliance. It appears to have effective working arrangements with the prosecution authorities and there is a track record of enforcement action, including criminal action. As a whole the system works effectively, although it is not clear whether BaFin is making as much use as it could of routine on-site inspection to create a regulatory presence in the market place and focus on the conduct of business issues that may not be apparent in reports analyzed off-site.

32. Principles for cooperation (Principles 11-13): BaFin has obligations to share information and cooperate with other domestic regulators, and these arrangements appear to work effectively in practice. These obligations also apply to ESAs in their role as exchange regulators. BaFin has sole responsibility for ensuring cooperation with foreign regulators, both within the EU and elsewhere. There are no material barriers to BaFin obtaining and sharing information with foreign counterparts about entities under its supervision or other persons, including where no breach of German law is at issue and it can use the same investigative powers for this activity as it uses to carry out its own investigations. BaFin is a signatory of the IOSCO Multilateral Memorandum of Understanding (MMOU), and many bilateral memorandums of understanding (MOUs). There is good evidence of BaFin's practical cooperation with foreign regulators.

\footnotetext{
${ }^{5}$ Examples include ship investment, real estate, and private equity funds. Data on the overall size of activity in grey markets are not readily available.
} 
33. Principles for issuers (Principles 14-16): A prospectus approved by BaFin is required for securities offered to the public or admitted to trading on a regulated market. Prospectus content requirements conform to IOSCO principles. Issuers are also subject to requirements for audited annual financial reports; half yearly reports; and interim management statements. Material event reporting also applies for issuers of securities traded on a regulated market. Financial statements must be prepared in accordance with International Financial Reporting Standards (IFRS) as adopted in EU for issuers that consolidate; and under German accounting standards for other issuers. Issuers that submit company-only statements can issue them in accordance to national standards. BaFin monitors compliance by issuers with reporting and disclosure obligations; the Financial Reporting Enforcement Panel reviews compliance by issuers with financial statement requirements, and BaFin takes enforcement action for breaches. Substantial shareholder disclosure and specific takeover legislation, including mandatory bid requirements, provide an effective framework for change of control transactions.

34. Principles for collective investment schemes (CIS) (Principles 17-20): Operators of CIS schemes must hold a license issued by BaFin. Licensing criteria that must be met include integrity requirements for managers and holders of more than 10 percent shareholdings; managers' competence; adequacy of internal controls and risk management systems; and minimum capital. Funds rules and changes to them must be approved by BaFin. BaFin reviews all prospectuses. CIS operators (both asset management companies and investment stock corporations) must keep fund assets segregated and use a licensed bank to hold fund assets and perform other roles. Operators must prepare and publish annual and semi-annual reports for each fund, and are subject to annual audits focusing on their compliance with legislative requirements. Each CIS requires a prospectus, the content of which accords with IOSCO Principles, and the operator must lodge a copy with BaFin. Asset valuation methodology is detailed in the legislation, as is the way prices are to be calculated on issue and redemption of units. There is specific accounting standards legislation to be used in valuing assets. BaFin uses annual audit reports extensively in its supervision of compliance by CIS operators. It does a small number of on-site inspections and relies to a large degree on the review of audit and other reports and the comments made in relation Principle 10 apply to this area of activity.

35. Principles for intermediaries (Principles 21-24): A license issued by BaFin is required to carry on a business of providing financial services, which is defined broadly to cover a broad range of financial market activity, including proprietary trading and providing customer-specific advice about financial instruments. Licensing criteria include integrity requirements for managers and holders of more than 10 percent shareholdings; managers' competence; adequacy of internal controls and risk management systems; and minimum capital requirements (the level of which varies according to the nature of the activities undertaken). Ongoing risk-based capital requirements, mainly reflecting the institution's credit and market risk, and other prudential requirements are also imposed on bank intermediaries permitted to hold client funds or assets; other intermediaries are not permitted 
to hold client fund or assets and are subject to the minimum capital requirement and a general obligation to remain solvent. Licensees must submit monthly reports about their financial position and compliance with prudential standards (where required) to the Bundesbank, which passes them on to BaFin with its analysis. BaFin also receives daily reports of all market transactions by licensed entities. The comments made under Principle 10 apply to BaFin's monitoring arrangements, especially in relation to on-site inspections, with regard to licensed intermediaries.

36. Principles for secondary markets (Principles 25-30): Exchanges and MTFs require authorization by the relevant State authority (ESA) or by BaFin (for MTFs). Exchange markets are subject to continuous supervision by the Trading Surveillance Offices (TSOs) and ESAs, with BaFin responsible for investigating and taking action on market abuse. The two MTFs are subject to direct supervision by BaFin, but this does not appear as intensive as that applying to exchange markets. The transparency obligations required by MiFID are in place for exchange markets and MTFs and apply to trading in shares and certificates representing shares, but not other instruments traded on regulated markets. Given that there are multiple venues on which shares can be traded, both within Germany and elsewhere, the absence of standards for consolidation of post trade information detracts from the overall transparency of the market for trading in shares.

\section{Table 1. Summary Implementation of the IOSCO Principles}

FI: Fully implemented

BI: Broadly implemented

PI: Partially implemented

NI: Not implemented.

NA: Not applicable.

\begin{tabular}{|l|c|l|}
\hline \multicolumn{1}{|c|}{ Principle } & Grading & \multicolumn{1}{c|}{ Findings } \\
\hline $\begin{array}{l}\text { Principle 1. The } \\
\text { responsibilities of the } \\
\text { regulator should be clearly } \\
\text { and objectively stated }\end{array}$ & BI & $\begin{array}{l}\text { The responsibilities of BaFin and the State-based } \\
\text { ESAs are clearly established by law. Market } \\
\text { participants understand the role played by BaFin, } \\
\text { and exchange markets understand the role of the } \\
\text { ESAs and exchange TSOs. Legislation requires } \\
\text { cooperation and information sharing between the } \\
\text { main regulators and other authorities with a }\end{array}$ \\
& & $\begin{array}{l}\text { regulatory role impacting on securities markets. } \\
\text { However, at the time of the assessment, advice on, } \\
\text { selling, and marketing of certain investment } \\
\text { products (such as closed-end funds) was not } \\
\end{array}$ \\
& regulated as fully as are other investment services, \\
\hline
\end{tabular}




\begin{tabular}{|c|c|c|}
\hline Principle & Grading & Findings \\
\hline & & $\begin{array}{l}\text { although the approval process for prospectuses has } \\
\text { been unified. }{ }^{6}\end{array}$ \\
\hline $\begin{array}{l}\text { Principle } 2 \text {. The regulator } \\
\text { should be operationally } \\
\text { independent and accountable } \\
\text { in the exercise of its functions } \\
\text { and powers }\end{array}$ & $\mathbf{P I}$ & $\begin{array}{l}\text { BaFin is operationally independent. It has a strong } \\
\text { line of accountability and detailed obligations to } \\
\text { provide information to the BMF about its activities. } \\
\text { BMF approval is not required for its operational } \\
\text { decisions as a regulator. Security of tenure of its } \\
\text { most senior management is not formally provided } \\
\text { for but is de facto well-entrenched. } \\
\text { The ESAs are separate units within the relevant } \\
\text { State Ministry (for example Frankfurt stock } \\
\text { exchange, and Eurex are supervised by an ESA } \\
\text { located within the Hessian Ministry of Economic } \\
\text { Affairs, Transportation and Regional Development). } \\
\text { This structure does not meet the formal standards } \\
\text { for independence required by the IOSCO principles. } \\
\text { Although in practice ESAs do not appear to be } \\
\text { subject to political interference, the institutional } \\
\text { structure of exchange market supervision remains } \\
\text { open to the potential for political direction. }\end{array}$ \\
\hline $\begin{array}{l}\text { Principle } 3 \text {. The regulator } \\
\text { should have adequate } \\
\text { powers, proper resources and } \\
\text { the capacity to perform its } \\
\text { functions and exercise its } \\
\text { powers }\end{array}$ & FI & $\begin{array}{l}\text { BaFin has extensive powers, including licensing } \\
\text { and ongoing supervisory and enforcement powers. } \\
\text { The fact that BaFin can only make enforceable } \\
\text { rules in relation to specific matters expressly } \\
\text { provided for by the Parliament may limit its ability to } \\
\text { react quickly in a crisis. Resources appear } \\
\text { adequate. BaFin staff are largely career civil } \\
\text { servants, but where needed, BaFin can employ } \\
\text { expertise outside the civil service framework. } \\
\text { The State-based ESAs (and under them exchange } \\
\text { TSOs) have the powers needed to carry out their } \\
\text { functions. }\end{array}$ \\
\hline $\begin{array}{l}\text { Principle } 4 \text {. The regulator } \\
\text { should adopt clear and } \\
\text { consistent regulatory } \\
\text { processes }\end{array}$ & FI & $\begin{array}{l}\text { As public authorities, BaFin and the ESAs (and the } \\
\text { TSOs) are subject to a comprehensive } \\
\text { administrative law regime that requires consistency } \\
\text { and fairness. There is no formal requirement for } \\
\text { BaFin to take compliance costs into account when } \\
\text { formulating policy, but BaFin plays a very limited } \\
\text { role in policy formation, which occurs at the BMF } \\
\text { level. }\end{array}$ \\
\hline
\end{tabular}

\footnotetext{
${ }^{6}$ Proposals were published in April 2011 to treat "grey market" products as other financial instruments and to provide full BaFin supervision over investment services in grey capital market products performed by investment firms under BaFin's supervision.
} 


\begin{tabular}{|c|c|c|}
\hline Principle & Grading & Findings \\
\hline $\begin{array}{l}\text { Principle } 5 . \text { The staff of the } \\
\text { regulator should observe the } \\
\text { highest professional } \\
\text { standards }\end{array}$ & $\mathbf{F I}$ & $\begin{array}{l}\text { Staff of BaFin are bound by extensive obligations- } \\
\text { including confidentiality obligations that apply to the } \\
\text { civil service generally, and in addition BaFin has } \\
\text { adopted internal policies (for example in relation to } \\
\text { disclosure of trading by staff) to supplement these } \\
\text { broad obligations. }\end{array}$ \\
\hline $\begin{array}{l}\text { Principle } 6 \text { The regulatory } \\
\text { regime should make } \\
\text { appropriate use of self- } \\
\text { regulatory organizations } \\
\text { (SROs) that exercise some } \\
\text { direct oversight responsibility } \\
\text { for their respective areas of } \\
\text { competence and to the extent } \\
\text { appropriate to the size and } \\
\text { complexity of the markets }\end{array}$ & $\mathrm{n} / \mathrm{a}$ & $\begin{array}{l}\text { Note: the regulatory role played by exchanges and } \\
\text { especially the TSOs that each exchange has are } \\
\text { dealt with under the Principles for secondary } \\
\text { markets. Under German law, exchanges and their } \\
\text { TSOs are public law entities subject to the general } \\
\text { framework for public authorities, not private law } \\
\text { entities under delegated authority. }\end{array}$ \\
\hline $\begin{array}{l}\text { Principle } 7 . \text { SROs should be } \\
\text { subject to the oversight of the } \\
\text { regulator and should observe } \\
\text { standards of fairness and } \\
\text { confidentiality when } \\
\text { exercising powers and } \\
\text { delegated responsibilities }\end{array}$ & n/a & \\
\hline $\begin{array}{l}\text { Principle } 8 \text {. The regulator } \\
\text { should have comprehensive } \\
\text { inspection, investigation and } \\
\text { surveillance powers }\end{array}$ & FI & $\begin{array}{l}\text { The regulators have broad supervisory, } \\
\text { investigative and enforcement powers over } \\
\text { regulated entities, and extensive information } \\
\text { gathering and in appropriate cases enforcement } \\
\text { powers not confined to regulated entities. }\end{array}$ \\
\hline $\begin{array}{l}\text { Principle } 9 . \text { The regulator } \\
\text { should have comprehensive } \\
\text { enforcement powers }\end{array}$ & FI & $\begin{array}{l}\text { BaFin has extensive powers to requisition } \\
\text { information, inspect documents, and enter } \\
\text { premises. It can compel individuals to give it oral } \\
\text { evidence (but not so as to involve self- } \\
\text { incrimination). It can take a range of enforcement } \\
\text { action directly, including by imposing substantial } \\
\text { administrative fines. Criminal investigation and } \\
\text { prosecution is the responsibility of the public } \\
\text { prosecutor. } \\
\text { ESAs appear to have powers adequate to enable } \\
\text { them to be credible regulators of exchange markets } \\
\text { under the Exchange Act. }\end{array}$ \\
\hline $\begin{array}{l}\text { Principle 10.The regulatory } \\
\text { system should ensure an } \\
\text { effective and credible use of } \\
\text { inspection, investigation, } \\
\text { surveillance and enforcement } \\
\text { powers and implementation of } \\
\text { an effective compliance }\end{array}$ & BI & $\begin{array}{l}\text { In broad terms, BaFin has a credible and effective } \\
\text { monitoring and enforcement program. But its } \\
\text { monitoring programs are heavily based on analysis } \\
\text { of material reported to it, including annual audit } \\
\text { reports on compliance by regulated entities, and it } \\
\text { makes limited use of its on-site inspection powers. } \\
\text { For regulation of market intermediaries and CIS }\end{array}$ \\
\hline
\end{tabular}




\begin{tabular}{|c|c|c|}
\hline Principle & Grading & Findings \\
\hline program. & & $\begin{array}{l}\text { operators, this approach may not detect concerns } \\
\text { in a timely manner, especially relating to conduct of } \\
\text { business as market conditions and market } \\
\text { participant behaviors change. } \\
\text { Insofar as it was assessed, the role played by ESAs } \\
\text { seems appropriate to their function. }\end{array}$ \\
\hline $\begin{array}{l}\text { Principle } 11 \text { The regulator } \\
\text { should have the authority to } \\
\text { share both public and non- } \\
\text { public information with } \\
\text { domestic and foreign } \\
\text { counterparts }\end{array}$ & FI & $\begin{array}{l}\text { BaFin and other regulators involved in the } \\
\text { regulation of securities markets are obliged to } \\
\text { cooperate and support one another's functions, and } \\
\text { have extensive information sharing powers. There } \\
\text { are no materially significant limits on BaFin's ability } \\
\text { to share information with other regulators in the EU, } \\
\text { and with foreign regulators, or preconditions to it } \\
\text { doing so. }\end{array}$ \\
\hline $\begin{array}{l}\text { Principle 12. Regulators } \\
\text { should establish information } \\
\text { sharing mechanisms that set } \\
\text { out when and how they will } \\
\text { share both public and } \\
\text { non-public information with } \\
\text { their domestic and foreign } \\
\text { counterparts }\end{array}$ & FI & $\begin{array}{l}\text { BaFin participates fully in European information } \\
\text { sharing arrangements, is a signatory to the IOSCO } \\
\text { MMOU, and has entered many unilateral MOUs } \\
\text { with foreign regulators. There is good evidence that } \\
\text { these arrangements are working in practice and } \\
\text { result in a considerable flow of information between } \\
\text { regulators, both domestically and internationally. }\end{array}$ \\
\hline $\begin{array}{l}\text { Principle } 13 . \text { The regulatory } \\
\text { system should allow for } \\
\text { assistance to be provided to } \\
\text { foreign regulators who need } \\
\text { to make inquiries in the } \\
\text { discharge of their functions } \\
\text { and exercise of their powers }\end{array}$ & FI & $\begin{array}{l}\text { BaFin has no power to directly represent foreign } \\
\text { regulators formally, for example in court } \\
\text { proceedings. But it can and does assist foreign } \\
\text { regulators to gather information and evidence, and } \\
\text { provide other forms of practical assistance. }\end{array}$ \\
\hline $\begin{array}{l}\text { Principle 14. There should be } \\
\text { full, timely and accurate } \\
\text { disclosure of financial results } \\
\text { and other information that is } \\
\text { material to investors' } \\
\text { decisions }\end{array}$ & FI & $\begin{array}{l}\text { To offer securities to the public or have them } \\
\text { admitted to trading on a regulated market, issuers } \\
\text { must have a prospectus approved by BaFin, the } \\
\text { content of which is in line with IOSCO standards. } \\
\text { Issuers must also publish annual and half yearly } \\
\text { reports, and (for issuers of shares) interim } \\
\text { management statements or quarterly reports. They } \\
\text { must disclose material price sensitive information } \\
\text { without delay. BaFin has published extensive } \\
\text { guidance to assist issuers with their obligations, } \\
\text { and its supervision of compliance with these } \\
\text { obligations is effective. }\end{array}$ \\
\hline $\begin{array}{l}\text { Principle } 15 . \text { Holders of } \\
\text { securities in a company } \\
\text { should be treated in a fair and } \\
\text { equitable manner }\end{array}$ & FI & $\begin{array}{l}\text { German company legislation provides the basic } \\
\text { framework for shareholders rights. Assertion of } \\
\text { these rights is a private law matter. Separate law } \\
\text { deals with company insolvency. The securities } \\
\text { legislation has a transparency regime for } \\
\text { substantial shareholdings. Comprehensive takeover } \\
\text { legislation is administered by BaFin, and includes a }\end{array}$ \\
\hline
\end{tabular}




\begin{tabular}{|c|c|c|}
\hline Principle & Grading & Findings \\
\hline & & $\begin{array}{l}\text { mandatory bid requirement when a person reaches } \\
\text { a } 30 \text { percent holding, and disclosure rules. There is } \\
\text { good evidence of BaFin's use of its powers to } \\
\text { ensure compliance with disclosure requirements for } \\
\text { substantial shareholdings and obligations under } \\
\text { takeovers legislation. }\end{array}$ \\
\hline $\begin{array}{l}\text { Principle } 16 \text {. Accounting and } \\
\text { auditing standards should be } \\
\text { of a high and internationally } \\
\text { acceptable quality }\end{array}$ & FI & $\begin{array}{l}\text { Issuers of traded securities must prepare and have } \\
\text { audited consolidated financial statements that } \\
\text { comply with IFRS; other issuers must prepare } \\
\text { accounts in accordance with German accounting } \\
\text { standards. German national accounting standards } \\
\text { are generally in line with international standards. } \\
\text { Auditors must apply auditing standards which are } \\
\text { analogous to the ISAs. Accounting standards are } \\
\text { provided for in legislation supplemented by } \\
\text { elaboration and guidelines set by a private body } \\
\text { under an agreement with German Ministry of } \\
\text { Justice. Audit standards are set by a private body. . } \\
\text { Issuers' compliance with financial reporting } \\
\text { standards is monitored by the Financial Reporting } \\
\text { Enforcement Panel, and by BaFin (which is } \\
\text { responsible for enforcement action). Compliance } \\
\text { with auditors' obligations (including independence } \\
\text { obligations) and compliance with audit standards is } \\
\text { monitored by the Chamber of Auditors, which is } \\
\text { itself supervised by the Auditor Oversight } \\
\text { Commission. }\end{array}$ \\
\hline $\begin{array}{l}\text { Principle } 17 . \text { The regulatory } \\
\text { system should set standards } \\
\text { for the eligibility and the } \\
\text { regulation of those who wish } \\
\text { to market or operate a } \\
\text { collective investment scheme }\end{array}$ & PI & $\begin{array}{l}\text { CIS operators can operate as asset management } \\
\text { companies or investment companies, and must be } \\
\text { licensed by BaFin and meet eligibility criteria, } \\
\text { including integrity requirements for managers and } \\
\text { significant owners, minimum capital, and internal } \\
\text { controls and risk management systems. The } \\
\text { content of advertising is regulated by the } \\
\text { investment legislation. Marketing of CISs can be } \\
\text { undertaken without requiring a license issued by } \\
\text { BaFin (provided no other BaFin regulated activity is } \\
\text { involved), but is then regulated by licensing } \\
\text { arrangements under the general commercial code. } \\
\text { In its monitoring of compliance by CIS operators, } \\
\text { BaFin is heavily reliant on analysis of audit reports, } \\
\text { and does not have an intensive on-site inspection } \\
\text { program. Such heavy reliance on audit reports } \\
\text { increases the chance that undesirable conduct is } \\
\text { not detected in a timely fashion, thereby increasing } \\
\text { risks to market performance, investor protection, } \\
\text { and BaFin's reputation. Although all CIS operators } \\
\text { and funds are subject to external audits, ongoing }\end{array}$ \\
\hline
\end{tabular}




\begin{tabular}{|c|c|c|}
\hline Principle & Grading & Findings \\
\hline & & $\begin{array}{l}\text { monitoring does not normally involve sufficient } \\
\text { performance of on-site inspections of entities } \\
\text { involved in operating CIS, given the materiality of } \\
\text { the sector. }\end{array}$ \\
\hline $\begin{array}{l}\text { Principle } 18 . \text { The regulatory } \\
\text { system should provide for } \\
\text { rules governing the legal form } \\
\text { and structure of collective } \\
\text { investment schemes and the } \\
\text { segregation and protection of } \\
\text { client assets }\end{array}$ & FI & $\begin{array}{l}\text { The legislation and fund rules approved by BaFin } \\
\text { govern the legal form of CIS and the rights of } \\
\text { investors. Fund assets must be kept separate from } \\
\text { those of the operator, and be held by a licensed } \\
\text { custodian bank approved by BaFin. Individual fund } \\
\text { rules must be approved by BaFin. }\end{array}$ \\
\hline $\begin{array}{l}\text { Principle 19. Regulation } \\
\text { should require disclosure, as } \\
\text { set forth under the principles } \\
\text { for issuers, which is } \\
\text { necessary to evaluate the } \\
\text { suitability of a collective } \\
\text { investment scheme for a } \\
\text { particular investor and the } \\
\text { value of the investor's interest } \\
\text { in the scheme }\end{array}$ & FI & $\begin{array}{l}\text { For retail funds CIS, the CIS operator must issue a } \\
\text { full prospectus and a simplified prospectus (to be } \\
\text { replaced by the Key Information Document by mid } \\
2011 \text { ) and lodge a copy of the prospectus with } \\
\text { BaFin. Both full and simplified prospectuses must } \\
\text { contain information necessary for investors to make } \\
\text { an informed judgment, including about risks. The } \\
\text { simplified prospectus regime will be replaced by a } \\
\text { requirement for a Key Investor Information } \\
\text { document as part of the German implementation of } \\
\text { UCITS IV. } \\
\text { Operators must also publish annual and half yearly } \\
\text { reports for each fund containing financial and other } \\
\text { information about fund activities. }\end{array}$ \\
\hline $\begin{array}{l}\text { Principle } 20 . \text { Regulation } \\
\text { should ensure that there is a } \\
\text { proper and disclosed basis for } \\
\text { assets valuation and the } \\
\text { pricing and the redemption of } \\
\text { units in a collective } \\
\text { investment scheme }\end{array}$ & FI & $\begin{array}{l}\text { The Investment Act and related legislation contains } \\
\text { detailed provisions for the valuation of CIS assets } \\
\text { that apply to all retail funds, covering rules for } \\
\text { valuation, the timing of valuations and the process } \\
\text { for valuation and the pricing of units on issue and } \\
\text { redemption. Compliance with these rules must be } \\
\text { monitored by internal audit and is subject to annual } \\
\text { external audit. The legislation also covers } \\
\text { procedures for the pricing of units both on issue } \\
\text { and on redemption. }\end{array}$ \\
\hline $\begin{array}{l}\text { Principle } 21 . \text { Regulation } \\
\text { should provide for minimum } \\
\text { entry standards for market } \\
\text { intermediaries }\end{array}$ & BI & $\begin{array}{l}\text { A person must hold an authorization issued by } \\
\text { BaFin to carry on a business of providing financial } \\
\text { services, a term that includes all forms of financial } \\
\text { market activity, including proprietary trading and } \\
\text { providing customer-specific advice about financial } \\
\text { instruments, and operating an MTF. Eligibility } \\
\text { standards include the integrity of managers and } \\
\text { owners of significant shareholdings, managers' } \\
\text { competence, resource requirements including } \\
\text { capital, and the adequacy of internal controls, risk } \\
\text { management and supervisory systems operational } \\
\text { requirements. Authorized institutions have } \\
\text { extensive reporting obligations, and BaFin carries }\end{array}$ \\
\hline
\end{tabular}




\begin{tabular}{|c|c|c|}
\hline Principle & Grading & Findings \\
\hline & & $\begin{array}{l}\text { out extensive reviews of these reports and external } \\
\text { audit reports, and some on-site inspections. See } \\
\text { comments under Principle } 10 .\end{array}$ \\
\hline $\begin{array}{l}\text { Principle 22. There should be } \\
\text { initial and ongoing capital and } \\
\text { other prudential requirements } \\
\text { for market intermediaries that } \\
\text { reflect the risks that the } \\
\text { intermediaries undertake }\end{array}$ & FI & $\begin{array}{l}\text { Authorized institutions (under the German } \\
\text { legislation this includes both credit institutions and } \\
\text { financial services institutions) are subject to } \\
\text { minimum capital requirements. Nonbank } \\
\text { intermediaries are not permitted to hold client } \\
\text { assets or funds, and as a consequence are not } \\
\text { subject to detailed ongoing risk-based capital } \\
\text { requirements. Banks conducting securities } \\
\text { business are subject to ongoing, risk-based } \\
\text { solvency and liquidity requirements monitored by } \\
\text { BaFin's Banking Directorate in collaboration with } \\
\text { the Bundesbank. Authorized institutions must } \\
\text { provide monthly returns which are reviewed both by } \\
\text { the Bundesbank and BaFin. BaFin conducts } \\
\text { extensive reviews of reports including annual } \\
\text { compliance audit reports. }\end{array}$ \\
\hline $\begin{array}{l}\text { Principle 23. Market } \\
\text { intermediaries should be } \\
\text { required to comply with } \\
\text { standards for internal } \\
\text { organization and operational } \\
\text { conduct that aim to protect } \\
\text { the interests of clients, ensure } \\
\text { proper management of risk, } \\
\text { and under which } \\
\text { management of the } \\
\text { intermediary accepts primary } \\
\text { responsibility for these } \\
\text { matters }\end{array}$ & FI & $\begin{array}{l}\text { Licensees must have risk management, compliance } \\
\text { and internal control functions. Compliance with } \\
\text { these requirements is subject to specific review in } \\
\text { the annual audit process, reviewed by BaFin. }\end{array}$ \\
\hline $\begin{array}{l}\text { Principle } 24 \text {. There should be } \\
\text { a procedure for dealing with } \\
\text { the failure of a market } \\
\text { intermediary in order to } \\
\text { minimize damage and loss to } \\
\text { investors and to contain } \\
\text { systemic risk }\end{array}$ & FI & $\begin{array}{l}\text { There are no specific ex ante procedures for } \\
\text { dealing with the consequences of the failure of an } \\
\text { intermediary. For the nonbank sector, BaFin would } \\
\text { deal with such a failure on an ad hoc basis, with a } \\
\text { focus on ensuring orderly winding up (through a } \\
\text { Court ordered insolvency process) and ensuring } \\
\text { clients of the firm are fully informed. For banks } \\
\text { involved in securities business, the Banking } \\
\text { Department would be responsible. }\end{array}$ \\
\hline $\begin{array}{l}\text { Principle } 25 \text {. The } \\
\text { establishment of trading } \\
\text { systems including securities } \\
\text { exchanges should be subject } \\
\text { to regulatory authorization } \\
\text { and oversight }\end{array}$ & FI & $\begin{array}{l}\text { Exchange markets require approval by the ESA of } \\
\text { the relevant State (Land) under the Stock } \\
\text { Exchange Act; MTFs must hold a license issued by } \\
\text { BaFin under the Banking Act. In each case, similar } \\
\text { preconditions must be met before approval is } \\
\text { granted. Exchange markets are monitored by } \\
\text { exchange Trading Supervisory Offices under the } \\
\text { supervision of ESAs. BaFin is responsible for }\end{array}$ \\
\hline
\end{tabular}




\begin{tabular}{|c|c|c|}
\hline Principle & Grading & Findings \\
\hline & & supervision of the two licensed MTFs. \\
\hline $\begin{array}{l}\text { Principle 26. There should be } \\
\text { ongoing regulatory } \\
\text { supervision of exchanges and } \\
\text { trading systems, which should } \\
\text { aim to ensure that the } \\
\text { integrity of trading is } \\
\text { maintained through fair and } \\
\text { equitable rules that strike an } \\
\text { appropriate balance between } \\
\text { the demands of different } \\
\text { market participants }\end{array}$ & FI & $\begin{array}{l}\text { TSOs conduct real time monitoring and supervision } \\
\text { of exchange markets, under the supervision of the } \\
\text { relevant ESA. ESAs monitor and respond to the } \\
\text { work of TSOs, and conduct periodic reviews of } \\
\text { overall exchange compliance. Currently two MTFs } \\
\text { are licensed by BaFin as investment services } \\
\text { enterprises under the Banking Act, subject to } \\
\text { additional MTF-specific obligations under the } \\
\text { Securities Trading Act. BaFin monitoring activity is } \\
\text { that applying to generally to market intermediaries. }\end{array}$ \\
\hline $\begin{array}{l}\text { Principle } 27 . \text { Regulation } \\
\text { should promote transparency } \\
\text { of trading }\end{array}$ & $\mathbf{B I}$ & $\begin{array}{l}\text { The regulatory framework provides for pre- and } \\
\text { post-trade transparency in equities, in line with } \\
\text { MiFID requirements, for exchange markets, MTFs } \\
\text { and systematic internalizers and permitted } \\
\text { exceptions are in line with market norms in other } \\
\text { jurisdictions. However, dispersal of trading across } \\
\text { multiple venues highlights the absence of an } \\
\text { integrated overview of activity. }\end{array}$ \\
\hline $\begin{array}{l}\text { Principle } 28 \text {. Regulation } \\
\text { should be designed to detect } \\
\text { and deter manipulation and } \\
\text { other unfair trading practices }\end{array}$ & FI & $\begin{array}{l}\text { Insider trading, market manipulation (and front } \\
\text { running) are both criminal and administrative } \\
\text { offences. The definitions for insider trading and } \\
\text { market manipulation are appropriately broad, and } \\
\text { apply to derivatives market activity as well as } \\
\text { securities markets. BaFin has an active program to } \\
\text { detect misconduct and enforce compliance, } \\
\text { supported by the ESAs and TSOs. BaFin reviews } \\
\text { daily trading reports from all market participants } \\
\text { and other information to assist it to detect market } \\
\text { abuse and insider trading. The enforcement record } \\
\text { indicates this activity is working well. }\end{array}$ \\
\hline $\begin{array}{l}\text { Principle 29. Regulation } \\
\text { should aim to ensure the } \\
\text { proper management of large } \\
\text { exposures, default risk and } \\
\text { market disruption }\end{array}$ & FI & $\begin{array}{l}\text { Derivatives trading platforms monitor large } \\
\text { positions and can set position limits. Large } \\
\text { counterparty exposures for banks subject to } \\
\text { prudential requirements are monitored as part of } \\
\text { the prudential supervision process. }\end{array}$ \\
\hline $\begin{array}{l}\text { Principle } 30 . \text { Systems for } \\
\text { clearing and settlement of } \\
\text { securities transactions should } \\
\text { be subject to regulatory } \\
\text { oversight, and designed to } \\
\text { ensure that they are fair, } \\
\text { effective and efficient and that } \\
\text { they reduce systemic risk }\end{array}$ & n/a & \\
\hline
\end{tabular}




\section{Recommended Action Plan and Authorities' Response}

37. The following recommendations aim to suggest measures to further improve the securities regulation framework and supervision.

\section{Table 2. Germany: Recommended Action Plan to Improve Compliance with the IOSCO Objectives and Principles for Securities Regulation}

\begin{tabular}{|c|c|}
\hline Reference Principle & Recommended Action \\
\hline $\begin{array}{l}\text { Responsibilities of the regulator } \\
\text { (Principle 1) }\end{array}$ & $\begin{array}{l}\text { The authorities should, as a matter of urgency, continue with } \\
\text { steps to ensure that uniform regulatory standards apply across } \\
\text { functionally similar financial market products and services, } \\
\text { especially with regard to standards for advice on, selling, and } \\
\text { marketing of products, as was recommended in } 2003 \text {. }\end{array}$ \\
\hline $\begin{array}{l}\text { Independence of the regulator } \\
\text { (Principle 2) }\end{array}$ & $\begin{array}{l}\text { The authorities should give consideration to: } \\
\text { a. mechanisms to strengthen the formal independence of the } \\
\text { State ESAs; } \\
\text { b. reviewing the reporting obligations of BaFin to the BMF with } \\
\text { a view to streamlining them; and } \\
\text { c. mechanisms, such as fixed term contracts, to ensure the } \\
\text { position of the president and senior management of BaFin } \\
\text { is secure and not open to potential arbitrary decisions } \\
\text { based on political or other non-performance related } \\
\text { considerations. }\end{array}$ \\
\hline $\begin{array}{l}\text { Regulatory compliance programs } \\
\text { (Principles 10,17 and 21) }\end{array}$ & $\begin{array}{l}\text { BaFin should continue to develop and refine its risk } \\
\text { assessment system, and make more intensive use of on-site } \\
\text { inspections by BaFin staff as part of its monitoring activities. } \\
\text { This will require additional resources. It is understood that } \\
\text { BaFin is moving in this direction. }\end{array}$ \\
\hline Market transparency (Principle 27) & $\begin{array}{l}\text { The authorities should work toward achieving a more complete } \\
\text { transparency regime in the context of the current European- } \\
\text { wide review of aspects of the MiFID regime. At a minimum } \\
\text { such a regime should include standards for data } \\
\text { interoperability, and it should result in an effective mechanism } \\
\text { to produce consolidated post-trade reporting for the equities } \\
\text { market. }\end{array}$ \\
\hline
\end{tabular}

\section{Authorities' response}

38. The authorities broadly agree with the assessment.

39. A proposal of the government on "grey capital market products" was published

in April 2011. The law is scheduled to be published at end-2011 or early 2012. According to the draft law, grey capital market products will be financial instruments in the terms of Securities Trading Act (Wertpapierhandelsgesetz, WpHG). The new definition of financial instruments will cover all grey market products, which are currently subject to the nonsecurities investment prospectus regime: this includes registered bonds, shares in civil-law 
partnerships, general partnerships or limited partnerships, silent partnerships, participation rights, trust units and units in other closed-end funds. According to the draft, the new regulation provides full BaFin supervision over investment services in grey capital market products performed by investment firms under BaFin's supervision. This means that the whole obligations of the $\mathrm{WpHG}$ are applicable.

\section{Enterprises which provide investment services in investment funds or grey} capital market products consisting solely of investment advice or investment brokerage to certain financial enterprises, and to the extent that the companies are not authorized to obtain ownership or possession of monies or shares from clients, will be supervised by the local commercial supervision authority. The mentioned enterprises are generally small entities with limited staff number or even run as sole trader business. Thus, full BaFin supervision including all legal requirements for investment firms seems inappropriate. However, core organizational requirements and rules of conduct of the securities trading act (WpHG) will be applicable according to the draft law. The applicable rules of WpHG will be specified in an ordinance following the law.

\section{Detailed Assessment}

\section{Table 3. Detailed Assessment of Implementation of the IOSCO Principles}

\begin{tabular}{|l|l|}
\hline \multicolumn{1}{|c|}{ Principles Relating to the Regulator } \\
\hline Principle 1. & The responsibilities of the regulator should be clear and objectively stated. \\
\hline Description & $\begin{array}{l}\text { Structure of the securities regulation regime } \\
\text { Regulation of securities and other financial markets in the Federal Republic of Germany } \\
\text { has a tiered structure. The main components of the regulatory regime are: } \\
\text { At the Federal level, BaFin is an integrated regulator with responsibility for banking, } \\
\text { insurance and securities supervision. Because of the major role banks play in the } \\
\text { securities industry, the Deutsches Bundesbank as well as BaFin play a significant role in } \\
\text { monitoring aspects of securities industry activity, for example by receiving and analyzing } \\
\text { reports for regulated intermediaries. } \\
\text { State authorities are responsible for authorization and regulation of exchanges that } \\
\text { operate securities and derivatives markets. ESAs have overall authority; each exchange } \\
\text { is a public body required to have a TSO, which operates under the supervision of the } \\
\text { relevant ESA. } \\
\text { Local (State-based) authorities are also responsible for authorization and supervision of } \\
\text { some entities not required to be licensed as financial services institutions under the } \\
\text { legislation administered by BaFin, such as intermediaries that provide advice or other } \\
\text { services in relation products (for example, closed-end funds) that are not regulated as } \\
\text { financial instruments under the Banking Act and the Securities Trading Act. } \\
\text { Responsibilities and powers } \\
\text { BaFin's responsibilities, power, and authority are set out in legislation. Its broad } \\
\text { objectives are to ensure the proper functioning, stability and integrity of the German } \\
\text { financial market, by counteracting undesirable developments in the banking and financial }\end{array}$ \\
\hline
\end{tabular}


services sector which may endanger the safety of assets entrusted to institutions, impair the proper conduct of banking business or financial services or lead to serious disadvantages for the economy as a whole. (See sections 4 and $\mathrm{s} 4 \mathrm{a} \mathrm{WpHG}$ and section $6 \mathrm{KWG}$ ).

Under the Federal Exchange Act (Börsengesetz, BörsG), responsibility for the authorization and ongoing supervision of exchange markets rests with ESAs, special units within State Government Ministries (normally the relevant Ministry of Finance or Ministry of Economics); and the TSOs of stock exchanges, which are required by the legislation to carry out mandated statutory functions.

Within BaFin, banking supervision, insurance supervision and securities/asset management supervision are carried out by three different organisational units (Directorates). Functions that extend beyond individual sectors are carried out by a Directorate that has cross-sectoral functions.

In the securities sector, BaFin is responsible for regulation of public issues of securities and other financial instruments; public issuers' reporting and disclosures; collective investment activity; market intermediaries; insider trading and other forms of market abuse; and markets not conducted by exchanges.

The Deutsches Bundesbank (Bundesbank) has a significant role in monitoring market intermediaries licensed by BaFin under the Banking Act (KWG). This includes the analysis of reports submitted credit institutions and financial services institutions.

BaFin derives all its responsibilities and functions, and its powers and authority, from legislation. In the securities sector, the body of legislation in this category is large, but the main laws are:

a. The Securities Trading Act (Wertpapierhandelsgesetz (WpHG))

b. The Securities Prospectus Act (Wertpapierprospektgesetz, (WpPG))

c. Act on the Prospectus for Securities Offered for Sale (Verkaufsprospektgesetz, (VerkProspG))

d. The Securities Acquisition and Takeover Act (Wertpapiererwerbs- und Übernahmegesetz, WpÜG)

e. The Banking Act (Kreditwesengesetz, KWG )

f. The Investment Act (Investmentgesetz, InvG).

This legislative framework is supplemented by other laws dealing with specific issues, such as legislation dealing with stock exchanges, the obligations of depositories, the solvency of intermediaries, money launderings; and by general laws (such as company law and commercial law) not administered by BaFin.

BaFin has authority for the securities market, with the exception of exchanges. The division of responsibility between BaFin and the State authorities is clearly delineated, and does not appear to give rise to gaps or overlaps.

BaFin, the ESAs and the TSOs are all public entities under German law and so subject to other legislation that applies generally to Government authorities, such as administrative procedures legislation.

\section{Discretion to interpret its authority}

BaFin must at all times act within the authority granted to it by legislation and in accordance with administrative law. It can provide guidance on the laws it administers and its approach to monitoring and enforcing compliance with them. It has issued extensive guidance, for example on the obligations of issuers, and CIS operators. 
BaFin does not have a general power to make rules that are legally binding on market participants. Under the German constitutional system of law, the power to make binding rules is reserved for the Parliament, or those to whom the Parliament expressly delegates the power to make subordinate legislation (regulations, ordinances). For the legislation $\mathrm{BaFin}$ is responsible for, the power to make subordinate legislation is ordinarily delegated to the BMF, but in some cases the legislation made by Parliament allows the BMF in turn to delegate this power to BaFin. In practice in the securities sector, this ordinarily applies only for technical matters such as the details of disclosures that the legislation requires regulated entities to make.

The role and responsibilities of ESAs and TSOs and other elements of the regulatory regime (such as stock exchange disciplinary committees) is specified in legislation and associated regulation and ordinances. These bodies must also act within the limits prescribed by such legislation.

\section{Coordination and cooperation between regulatory authorities}

BaFin, the Bundesbank, the Federal Cartel Office, ESAs and TSOs are obliged by legislation to cooperate with one another and share information, including personal data, needed for the performance of their functions. See especially $s 6 \mathrm{WpHG}$. Administrative law provisions require all public authorities to cooperate and communicate in shared areas of responsibility.

The Banking Act also has detailed provisions relating to the roles played by BaFin and the Bundesbank in the supervision entities licensed under the Banking Act, including requirements for information sharing. This framework is supported by an MOU and a guideline issued by BaFin on carrying out and ensuring the quality of the ongoing monitoring of credit and financial services institutions by the Deutsche Bundesbank.

In practice, there are regular formal and informal information flows and referrals from ESAs to BaFin.

BaFin must also report to the prosecutorial authorities without undue delay report facts giving rise to suspicion of a criminal offence (see $s 4 \mathrm{WpHG}$ ).

Assessment Broadly implemented

Comments

Although regulation of activity on exchange markets involves a division of responsibility and powers between BaFin and State-based authorities, the legislative framework is clear as to roles and functions. There do not appear to be any gaps or significant overlaps. TSOs under the supervision of State Authorities monitor compliance by exchanges and members' compliance by members with exchange the rules. They and the ESAs have a duty to report suspicions of market abuse to BaFin. BaFin receives transaction reports from licensed intermediaries for all market activity, and actively monitors for compliance with prohibitions on insider trading and other market abuse.

As noted in the 2003 assessment, the legislative framework does not provide for a fully uniform regulatory standards across the spectrum of financial instruments. Some products and services provided in relation to them-notably advice, marketing and distribution services - appear to be regulated differentially (for example, there is no Federal regulation of the selling function for closed-end funds, although the prospectuses for these funds are now subject to approval-see Principle 14). Selling and intermediation functions is subject to an authorization process under the Commercial Code administered by local authorities; the regulation imposed in this way is not as stringent as that applying to the financial instruments regulation administered by BaFin. 


\begin{tabular}{|c|c|}
\hline & $\begin{array}{l}\text { However, it is worth noting that all prospectuses are now subject to the same regime. } \\
\text { While it is difficult to gauge the extent of this "grey market" activity with accuracy, it } \\
\text { means there is a persisting risk of mis-selling of these products at the retail level. The } \\
\text { framework also has the potential for incentives to structure products activities so as to } \\
\text { avoid the cost of complying with the full securities regime; and the risk that substantial } \\
\text { misconduct in the sector will damage the confidence of retail investors in the investment } \\
\text { sector generally. } \\
\text { The assessor understands the authorities are developing proposals to address the risk of } \\
\text { mis-selling in the grey market and to provide more uniform regulation of advice and selling } \\
\text { function across the financial sector, and supports that initiative; Proposals for regulation of } \\
\text { these functions to a standard equivalent to the licensing regime administered by BaFin } \\
\text { were released for public comment in April } 2011 \text { (shortly after the date of the assessment). }\end{array}$ \\
\hline Principle 2. & $\begin{array}{l}\text { The regulator should be operationally independent and accountable in the exercise of its } \\
\text { functions and powers. }\end{array}$ \\
\hline Description & 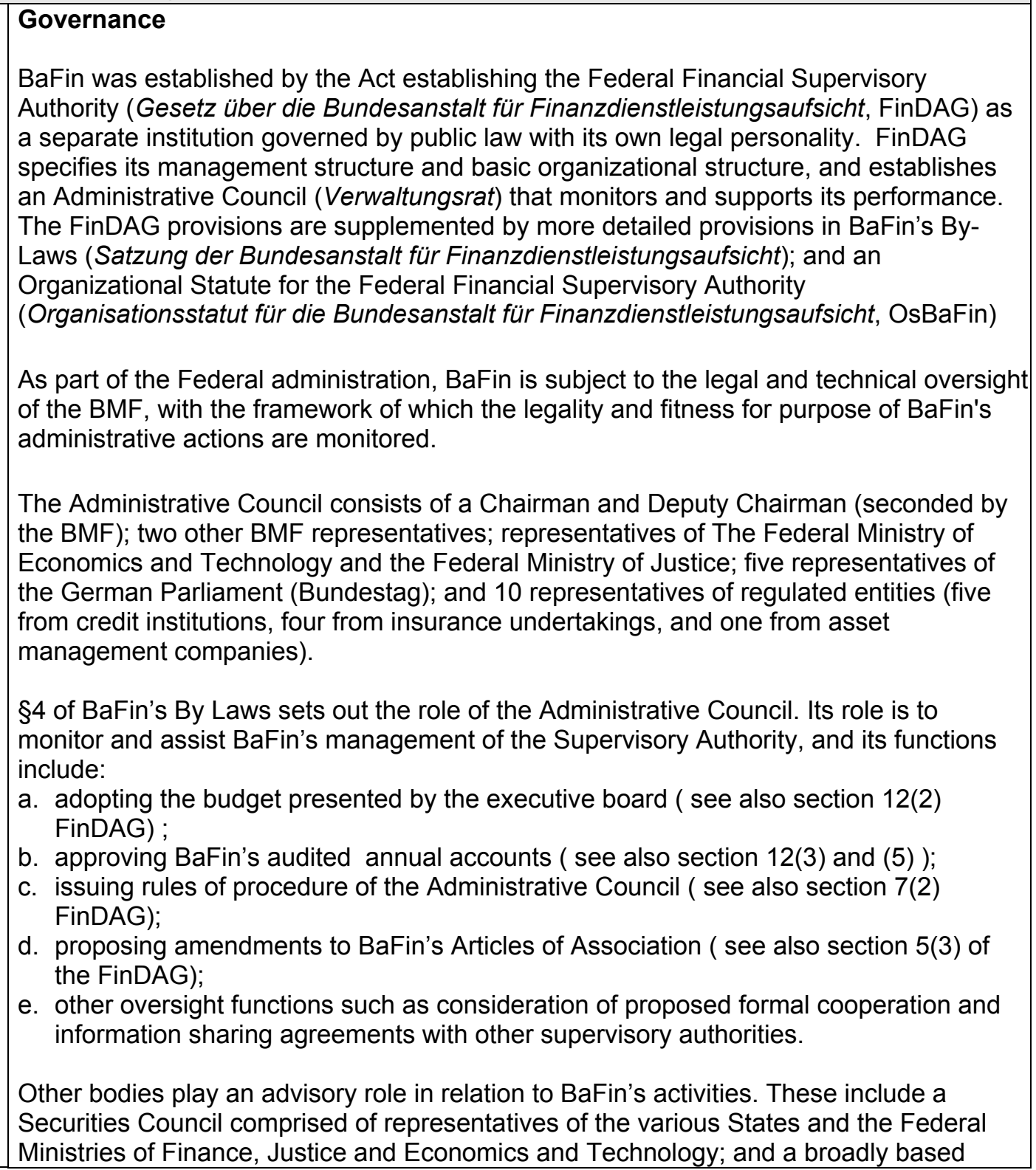 \\
\hline
\end{tabular}




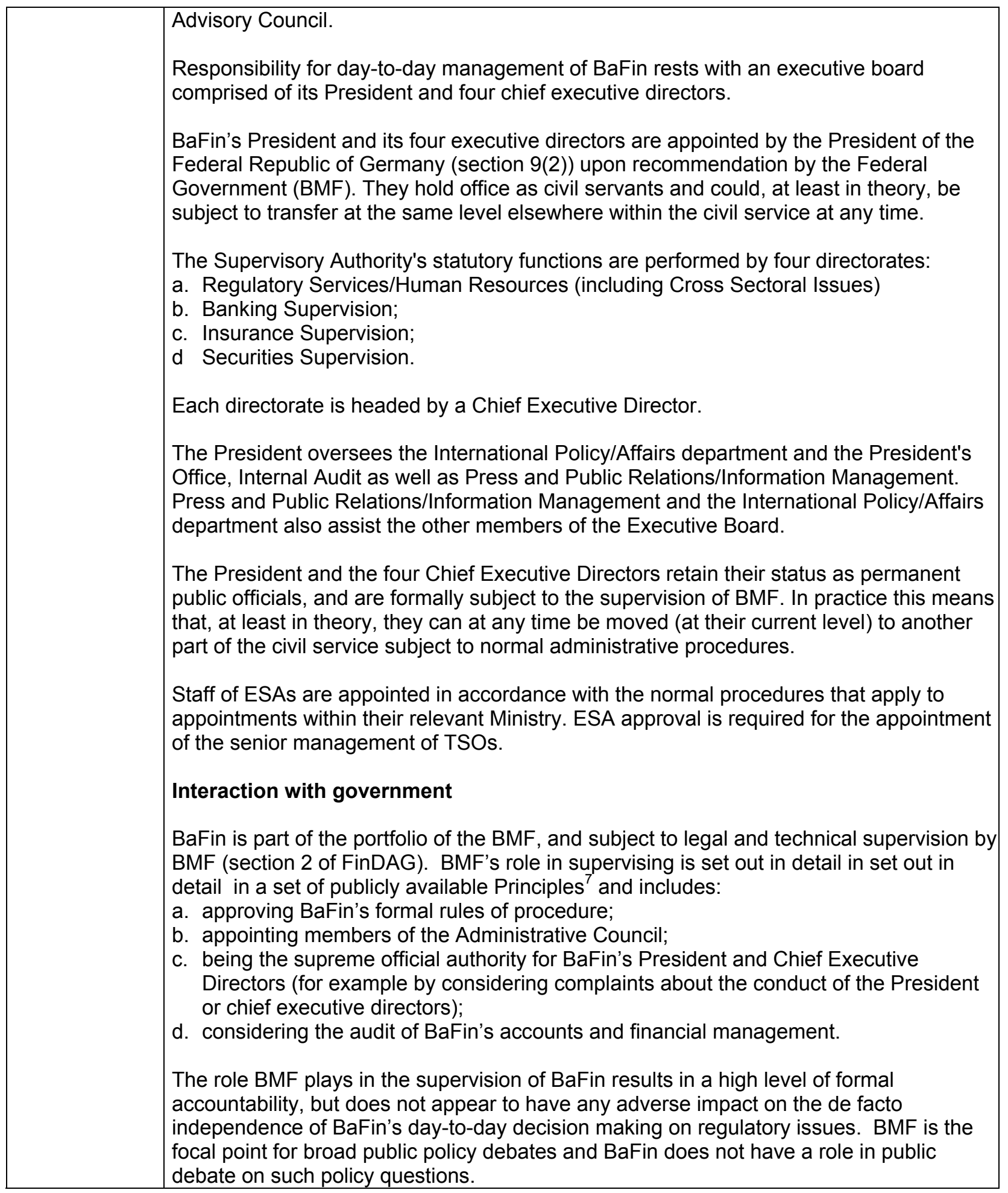

\footnotetext{
${ }^{7}$ Principles governing the exercise of legal and technical supervision of BaFin by the Federal Ministry of Finance, February 2010, available on the BaFin website: http://www.bafin.de/nn 721300/SharedDocs/Veroeffentlichungen/EN/BaFin/Grundlagen/gs aufsicht bmf bafin en.html.
} 


\begin{tabular}{|c|c|}
\hline & $\begin{array}{l}\text { Funding } \\
\text { FinDAG make BaFin responsible for drawing up its own budget and raising sufficient } \\
\text { revue to cover its costs. It does not rely on a budget allocation from the Federal } \\
\text { government. Revenue is derived from the entities it regulates in the form of: } \\
\text { a. fees charged for official acts; } \\
\text { b. reimbursements for costs it incurs, for example by appointing a liquidator or } \\
\text { commissioning an auditor; } \\
\text { c. contributions for regulated entities. } \\
\text { The actual amount of fees and contributions is calculated on the basis of the Ordinance } \\
\text { on the Imposition of Fees and Allocation of Costs Pursuant to the FinDAG (Verordnung } \\
\text { über die Erhebung von Gebühren und die Umlegung von Kosten nach dem } \\
\text { Finanzdienstleistungsaufsichtsgesetz - FinDAGKostV) and in accordance with special } \\
\text { rules governing the charges to be applied by BaFin. } \\
\text { In } 2010, \text { approximately } 88 \text { percent of BaFin's total budget of close to EUR } 160 \text { million } \\
\text { was derived from industry contributions. The fee proportion declined from } 25 \text { percent in } \\
2009 \text { to } 11 \text { percent. } \\
\text { The executive board draws up the budget each year for approval by the Administrative } \\
\text { Council. } \\
\text { Legal protection } \\
\text { Broad constitutional provisions that apply generally to Government employees } \\
\text { performing official functions protect BaFin staff from legal liability for acts or omissions, } \\
\text { provided they act in good faith. Individual liability arises only for intentional or grossly } \\
\text { negligent misconduct. These protections apply equally to staff of ESAs and TSOs. } \\
\text { Accountability } \\
\text { BaFin is accountable to the BMF, with the Ministry's supervisory powers set out in } \\
\text { FinDAG and in more detail in the Principles governing the exercise of legal and technical } \\
\text { supervision of BaFin by the BMF. These Principles contain quite detailed requirements } \\
\text { for BaFin to provide reports and other information to BMF (see Part III). These } \\
\text { requirements do not envisage pre-approval by BMF of BaFin's regulatory decisions, but } \\
\text { they do place a considerable reporting burden on it. } \\
\text { ESAs are administrative units within State Ministries and do not have separate legal } \\
\text { personality. } \\
\text { In accordance with ordinary principles of German administrative law, there are rights of } \\
\text { review available to those affected by decisions of BaFin and the ESAs, including by } \\
\text { courts. }\end{array}$ \\
\hline Assessment & Partially implemented \\
\hline Comments & $\begin{array}{l}\text { At a formal level, aspects of the German system do not meet the standards of } \\
\text { independence envisaged by the IOSCO principles. The clearest example is the location } \\
\text { of ESAs within State Ministries, which are directly accountable to and potentially subject } \\
\text { to the direction of the relevant Minister. } \\
\text { BaFin itself is operationally independent of government and accountable. However, it is } \\
\text { subject to full, and potentially burdensome, reporting obligations to BMF. In addition, the } \\
\text { senior management of BaFin is "embedded" within the civil service and not formally }\end{array}$ \\
\hline
\end{tabular}




\begin{tabular}{|c|c|}
\hline & $\begin{array}{l}\text { protected from transfer to other positions other than through the reputational risk this may } \\
\text { pose for government, and the limited number of comparable positions. } \\
\text { There seems to be no evidence of political interference in the day-to-day operations of } \\
\text { the ESAs or of BaFin. The express and detailed legislation that defines the } \\
\text { responsibilities and powers of the regulators in the securities sector itself contributes to } \\
\text { this de facto independence. } \\
\text { Authorities should give consideration to: } \\
\text { a. mechanisms to strengthen the formal independence of the State ESAs; } \\
\text { b. reviewing the reporting obligations of BaFin to BMF with a view to streamlining them; } \\
\text { c. mechanisms, such as fixed term contracts, to ensure the position of the President } \\
\text { and senior management of BaFin is secure and not open to potential arbitrary } \\
\text { decisions based on political or other non-performance related considerations. }\end{array}$ \\
\hline Principle 3. & $\begin{array}{l}\text { The regulator should have adequate powers, proper resources and the capacity to } \\
\text { perform its functions and exercise its powers. }\end{array}$ \\
\hline Description & 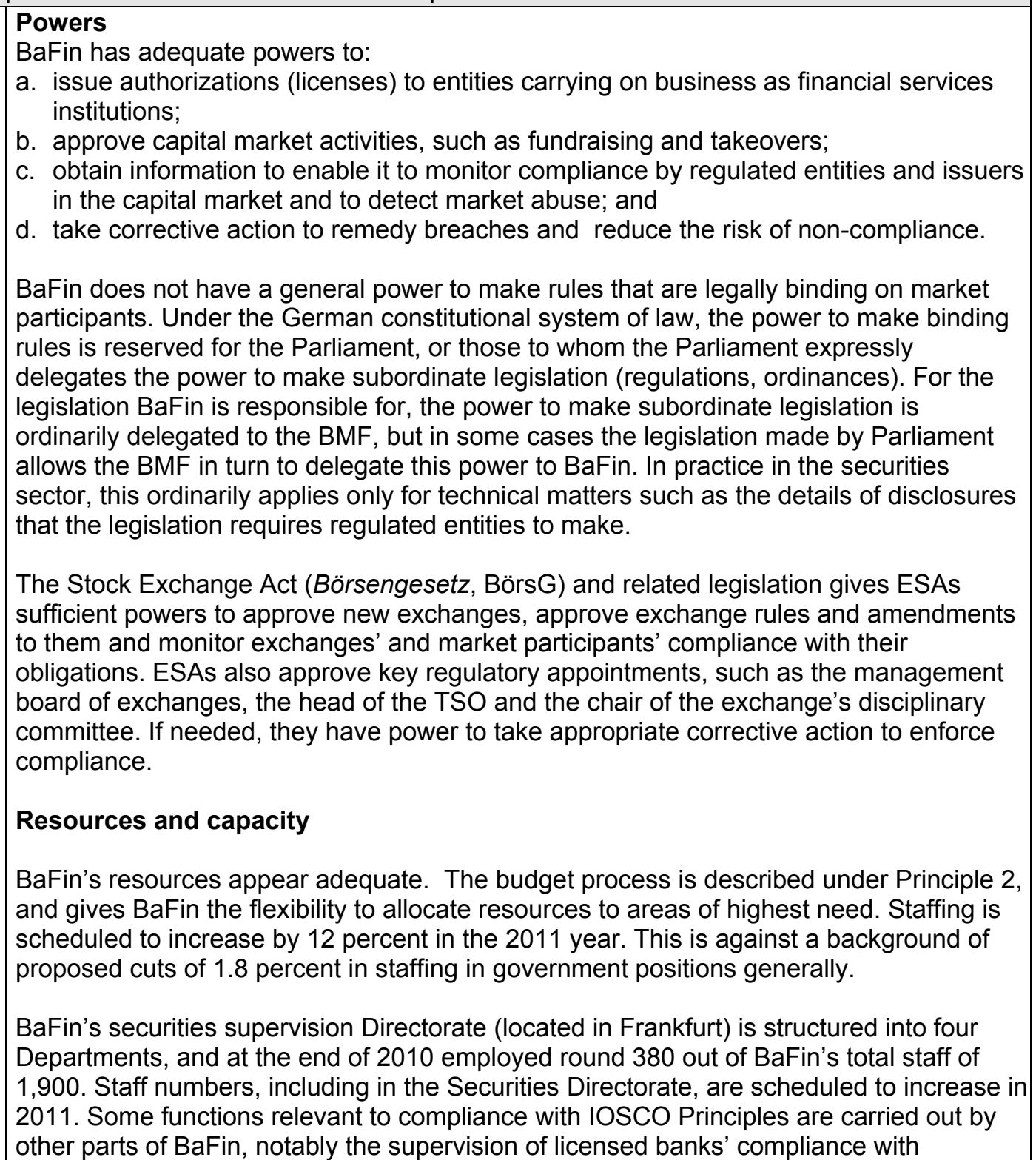 \\
\hline
\end{tabular}




\begin{tabular}{|c|c|}
\hline & $\begin{array}{l}\text { prudential and solvency rules. } \\
\text { BaFin staffs are largely permanent civil servants or public employees, but there is some } \\
\text { scope to employ specialist expertise outside the public sector remuneration framework. } \\
\text { Pay scales do not match those available in the financial markets, but employment is } \\
\text { secure and staffs generally make a career as BaFin employees. } \\
\text { Many BaFin staffs are recruited directly from their university studies at masters or } \\
\text { doctorate level, as well as from the private or professional sector. Training is provided } \\
\text { both through training programs and through rotation through different parts of BaFin in } \\
\text { the early stages of recruits' careers. }\end{array}$ \\
\hline Assessment & Fully implemented \\
\hline Comment & $\begin{array}{l}\text { BaFin has adequate powers and financial resources to be an effective regulator. It } \\
\text { employs professional staff with high qualifications. Its staff profile is largely permanent } \\
\text { civil servants and it may lack depth of industry experience in some areas. It may be } \\
\text { desirable for it to draw on industry expertise through, for example, secondments to } \\
\text { ensure staff have exposure to industry practice. }\end{array}$ \\
\hline Principle 4. & The regulator should adopt clear and consistent regulatory processes. \\
\hline Description & $\begin{array}{l}\text { Regulatory authorities (including BaFin and ESAs) are bound by general administrative } \\
\text { law provisions requiring consistent and fair processes. These processes are codified in } \\
\text { the Administrative Procedures Act (Verwaltungsverfahrensgesetz, VwVfG). In some } \\
\text { cases, they are supplemented by specific procedural requirements in the legislation } \\
\text { BaFin administers, such as the Securities Trading Act, the Securities Prospectus Act, } \\
\text { and the Takeovers Act. } \\
\text { The general administrative law legislation provides for fair and transparent procedures } \\
\text { and this is the basis for clear and consistent processes. } \\
\text { Procedures and guidance } \\
\text { Proposed rules, regulations and policies (other than some enforcement policies) are } \\
\text { subject to prior consultations with affected stakeholders and, where appropriate, to public } \\
\text { consultation. } \\
\text { Proposals are always published on the BaFin-website, and sometimes also circulated in } \\
\text { print form. BaFin also make public the comments it receives through the consultation } \\
\text { process. Important policies are often also subject to an additional hearing on BaFin's } \\
\text { premises. } \\
\text { All policies are, when adopted, made available on BaFin's website, as are changes to } \\
\text { existing policies and rules made by BaFin under delegated authority. } \\
\text { BaFin does not have a formal obligation to conduct formal cost-benefit analyses of } \\
\text { proposed rules or guidance, but its mission statement }{ }^{8} \text { commits it to both proportionality } \\
\text { and cost consciousness in carrying out its functions. } \\
\text { BaFin Decisions }\end{array}$ \\
\hline
\end{tabular}

\footnotetext{
${ }^{8}$ Published on BaFin's website at http://www.bafin.de/cln_179/nn 721300/EN/BaFin/Legalbasis/Missionstatement/missionstatement node.html ? nnn=true
} 


\begin{tabular}{|c|c|}
\hline & $\begin{array}{l}\text { The criteria on which BaFin makes decisions-including a decision to grant, deny or } \\
\text { revoke a license, and other regulatory decisions-are set out in the relevant legislation } \\
\text { and any associated guidance issued by BaFin. These decisions are administrative acts } \\
\text { to which } V w V f G \text { applies, including Section } 28 \text { which entitles the subject of the decision to } \\
\text { a hearing if they are not satisfied with the decision. Section } 39(1) \text { of } V w V f G \text { requires } \\
\text { reasons to be given for decisions that affect the rights or interests of others. } \\
\text { Under the Code of Administrative Court Procedures (Verwaltungsgerichtsordnung, } \\
\text { VwGO), BaFin's formal regulatory decisions can be appealed to formal judicial review. A } \\
\text { prior internal administrative review is required before judicial review. } \\
\text { BaFin does not generally make reports on investigations public, though it has the power } \\
\text { to do so when a proceeding is complete (section } 40 B \text { WpHG). } \\
\text { Investor Education } \\
\text { BaFin produces information sheets and leaflets that provide information to investors. Its } \\
\text { website has a consumer portal, a frequently asked questions facility, and provides readily } \\
\text { accessible databases listing all licensed firms, approved prospectuses, and major } \\
\text { holdings in voting rights. } \\
\text { BaFin does not have a broad mandate for financial literacy or generalized investor } \\
\text { education and its activities in this area are largely limited to those described above. }\end{array}$ \\
\hline Assessment & Fully implemented \\
\hline Comments & \\
\hline Principle 5. & $\begin{array}{l}\text { The staff of the regulator should observe the highest professional standards including } \\
\text { appropriate standards of confidentiality. }\end{array}$ \\
\hline Description & $\begin{array}{l}\text { BaFin staff are Federal Government employees and their obligations to observe } \\
\text { standards of professional conduct derive from three sources: } \\
\text { a. general administrative law provisions that apply to all Government employees, such } \\
\text { as the Federal Civil Service Act (Bundesbeamtengesetz, BBG); the Administrative } \\
\text { Procedures Act (VwVfG) and the Code of Criminal Procedure (Strafprozessordnung); } \\
\text { b. specific provisions in legislation that BaFin administers, such as the Securities } \\
\text { Trading Act, the Banking Act, the Takeovers Act and the Prospectus Act; and } \\
\text { c. regulations and internal instructions and directives such as regulations on personal } \\
\text { account dealings by BaFin staff; standing instructions for the prevention of corruption } \\
\text { at BaFin; and a directive on the acceptance of rewards and gifts. } \\
\text { This framework is supplemented by BaFin's internal control system which among other } \\
\text { things defines procedures, responsibilities and reporting lines; and establishes } \\
\text { compliance monitoring arrangements to detect and deal with potential misconduct. } \\
\text { The Banking Act (section } 9 \text { KWG) and the Securities Trading Act (Section } 8 \text { WpHG), } \\
\text { together with the Federal Data Protection Act require personal data and business/trade } \\
\text { secrets to be kept confidential. Breaches of these provisions may expose a staff member } \\
\text { to criminal penalties. Other specific legislation contains similar requirements. } \\
\text { The Regulation on the Monitoring of Personal Account Dealings: } \\
\text { a. prohibits any dealings by BaFin staff that may amount to insider trading under the } \\
\text { Securities Trading Act; } \\
\text { b. requires all BaFin staff to keep records of personal account dealings (dealing on the } \\
\text { account of a staff member or a relative or friend of a staff member); } \\
\text { c. requires BaFin staff who have or may have access to inside information (in practice, }\end{array}$ \\
\hline
\end{tabular}




\begin{tabular}{|c|c|}
\hline & $\begin{array}{l}\text { all regulatory staff of BaFin are in this category) to immediately report trading } \\
\text { transactions to senior management or a designated person; } \\
\text { d. establishes processes for monitoring compliance with these rules. } \\
\text { The Standing Instructions for the Prevention of Corruption at BaFin mandates that BaFin } \\
\text { appoints an anti-corruption officer and sets out the functions of that role. } \\
\text { Compliance by BaFin staff with these standards of professional conduct is the } \\
\text { responsibility of senior management, working with internal audit and the anti-corruption } \\
\text { officer. Senior management are also responsible for dealing with complaints about the } \\
\text { conduct of BaFin staff, expect for complaints about conduct by the President and Chief } \\
\text { Executive, for which BMF has responsibility. } \\
\text { Breaches by BaFin staff of professional standards expose them to administrative action, } \\
\text { and potentially to criminal sanctions (for example for insider trading). } \\
\text { Staff of ESAs are subject to similar standards of conduct through general administrative } \\
\text { law, specific provisions in the legislation they administer, and relevant internal } \\
\text { instructions that apply to staff in the Ministries they work in. }\end{array}$ \\
\hline Assessment & Fully implemented \\
\hline \multicolumn{2}{|l|}{ Comments } \\
\hline \multicolumn{2}{|r|}{ Principles of Self-Regulation } \\
\hline Principle 6. & $\begin{array}{l}\text { The regulatory regime should make appropriate use of Self-Regulatory Organizations } \\
\text { (SROs) that exercise some direct oversight responsibility for their respective areas of } \\
\text { competence, and to the extent appropriate to the size and complexity of the markets. }\end{array}$ \\
\hline Description & $\begin{array}{l}\text { Under the German system, only public law bodies perform regulatory functions and these } \\
\text { functions are defined by and specified in legislation. The role played by stock exchange } \\
\text { TSOs and other administrative bodies is within this characterization and for the purposes } \\
\text { of this assessment TSOs are not treated as SROs. The role played by TSOs and other } \\
\text { exchange bodies is described under the Principles for secondary markets. }\end{array}$ \\
\hline Assessment & NA \\
\hline \multicolumn{2}{|l|}{ Comments } \\
\hline Principle 7. & $\begin{array}{l}\text { SROs should be subject to the oversight of the regulator and should observe standards of } \\
\text { fairness and confidentiality when exercising powers and delegated responsibilities. }\end{array}$ \\
\hline Description & See comments under Principle 6. \\
\hline Assessment & NA \\
\hline \multicolumn{2}{|l|}{ Comments } \\
\hline Principle 8. & $\begin{array}{l}\text { The regulator should have comprehensive inspection, investigation and surveillance } \\
\text { powers. }\end{array}$ \\
\hline Description & $\begin{array}{l}\text { BaFin has extensive powers to monitor compliance by entities it regulates and other } \\
\text { persons subject to obligations or prohibitions under legislation it administers. } \\
\\
\text { Under the Securities Trading Act (Section } 4 \mathrm{WpHG} \text { ), BaFin has powers to require any } \\
\text { person (including a person who is not a regulated entity) to supply information and } \\
\text { documents and to answer questions, subject to safeguards provided by German } \\
\text { constitutional law. This power includes the power to compel a person to provide details } \\
\text { about changes in holdings of financial instruments, and the identity of those acquiring } \\
\text { rights under transactions. BaFin also has the power to enter premises, including without } \\
\text { prior notice. These powers give BaFin the authority to carry out on-site inspections of } \\
\text { regulated entities, whether on a routine or for-cause basis. }\end{array}$ \\
\hline
\end{tabular}


The Banking Act (section $44 \mathrm{KWG)}$ confers similarly broad powers to require information and carry out inspections in relation to credit and financial services institutions. The Investment Act empowers BaFin to issue any order deemed necessary to ensure compliance with that Act and related legislation (Section 5 InvG); and to require information and carry out inspections in relation to investment managers (Section $19 \mathrm{~g}$ InvG).

These powers can be used on a routine basis and do not require BaFin to suspect misconduct.

WpHG requires a regulated entity to make and keep records of its business activity, transactions and the use of customer funds. It also requires the entity to keep records of the investment services it provides in such a way as to permit BaFin to verify the entity's compliance with the legislation (see primarily Section 34 and also Section 25a KWG and section 9 a InvG). This includes records of client agreements, and minutes of investment advice provided to retail clients.

Records are required to be kept for a minimum of five years.

Particular record keeping rules also apply under the anti-money laundering legislation administered by BaFin, including customer identity data for specified types of transactions. Regulated entities also must report transactions involving suspect antimoney laundering or anti terrorist financing under the Money Laundering Act (Geldwäschegesetz), GwG).

BaFin has power to require investment services institutions to supply information about the identity of clients. In addition, some information regularly reported to BaFin (such as daily transaction reports submitted by investment services institutions) contains client identity information. See sections 4 and s9 WpHG.

\section{Use of external auditors}

In addition to the powers described above, BaFin makes extensive use of the results of compliance audits by regulated institutions' external auditors in its regulatory work. These audits fall into two groups:

a. routine annual compliance audits (see Section $36 \mathrm{WpHG}$ )

These audits are separate from the audit of financial statements and focus on an institution's compliance with conduct and organizational rules. BaFin has power to specify the scope of these audits, and determine points of emphasis. Auditors must report to BaFin without undue delay any serious contraventions of the institution's reporting or conduct obligations.

b. "special" audits (see Section $35 \mathrm{WpHG}$ )

These are audits commissioned by BaFin and carried out by an external auditor (normally other than the firm's usual auditor), or by BaFin staff directly, or-most commonly-by BaFin staff working with an external auditor. No special reason (such as suspected misconduct) or even prior notice is required for these audits.

The Stock Exchange Act (Section 3 BörsG) gives ESAs similar powers to those conferred on BaFin by The Securities Trading Act, including the power to seek information and documents from exchanges, exchange operators, trading participants and issuers of traded financial instruments. 


\begin{tabular}{|c|c|c|c|}
\hline & \multicolumn{3}{|c|}{$\begin{array}{l}\text { Principle 10. It does not result from any lack of power for BaFin itself to obtain } \\
\text { information, or to carry out on-site inspections, and BaFin's powers of inspection, } \\
\text { investigation, and surveillance are broad ranging. }\end{array}$} \\
\hline Principle 9. & \multicolumn{3}{|c|}{ The regulator should have comprehensive enforcement powers. } \\
\hline \multirow[t]{6}{*}{ Description } & \multicolumn{3}{|c|}{$\begin{array}{l}\text { BaFin has comprehensive powers to deal with breaches, or threatened breaches, of the } \\
\text { legislation it administers. These fall into three broad categories: } \\
\text { a. requiring a regulated entity to take corrective action; } \\
\text { b. imposing administrative penalties; and } \\
\text { c. referring a breach to the public prosecutor for prosecution as a criminal offence. } \\
\text { The authorities responsible for the regulation of stock exchanges (ESAs and TSOs) also } \\
\text { have appropriate powers to monitor and take action to preserve the integrity of market } \\
\text { trading. } \\
\text { Enforcement powers can be summarized in the following table: }\end{array}$} \\
\hline & $\begin{array}{l}\text { Enforceme } \\
\text { nt action }\end{array}$ & Legal foundation & Content/description \\
\hline & $\begin{array}{l}\text { Criminal } \\
\text { penalty }\end{array}$ & $\begin{array}{l}\text { § } 38 \mathrm{WpHG}, \S 54 \\
\text { KWG }\end{array}$ & $\begin{array}{l}\text { Insider trading and market manipulation is a } \\
\text { crime according to } \S 38 \mathrm{WpHG} \text {. The penalty } \\
\text { is a monetary fine or imprisonment up to five } \\
\text { years. } \\
\text { Providing prohibited banking services or } \\
\text { providing banking or investment services } \\
\text { without a permission of BaFin is a crime } \\
\text { according to } \S 54 \mathrm{KWG.} \mathrm{The} \mathrm{penalty} \mathrm{is} \mathrm{a} \\
\text { monetary fine or imprisonment up to three } \\
\text { years. }\end{array}$ \\
\hline & $\begin{array}{l}\text { Administrat } \\
\text { ive fines }\end{array}$ & $\begin{array}{l}\text { § } 39 \text { WpHG, } \$ 56 \\
\text { KWG, § } 30 \text { WpPG, } \\
\S 17 \text { VerkProspG, } \\
\S 143 \text { InvG, § } 60 \\
\text { WpÜG }\end{array}$ & $\begin{array}{l}\text { All relevant obligations in the securities } \\
\text { supervision are subject to an administrative } \\
\text { fine in case of an intentional or negligent } \\
\text { breach of the respective rules. Depending } \\
\text { on the importance of the violated regulation } \\
\text { fines ranging from up to } 50.000 \text { Euro to a } \\
\text { maximum fine of } 1.000 .000 \text { Euro. The } \\
\text { amount is adjusted by BaFin according to } \\
\text { the individual case and is subject to a } \\
\text { judicial review if requested by the fined } \\
\text { person. The economic profit of an offence } \\
\text { can be withdrawn without a specific } \\
\text { limitation. }\end{array}$ \\
\hline & $\begin{array}{l}\text { Penalty } \\
\text { payment, } \\
\text { coercive } \\
\text { detention, } \\
\text { execution } \\
\text { by } \\
\text { substitution }\end{array}$ & $\begin{array}{l}\text { VwVG } \\
\text { (Verwaltungsvollstr } \\
\text { eckungsgesetz - } \\
\text { Act on } \\
\text { Administrative } \\
\text { Enforcement) }\end{array}$ & $\begin{array}{l}\text { All administrative measures of BaFin can be } \\
\text { enforced by penalty payment, coercive } \\
\text { detention or execution by substitution. All } \\
\text { unfulfilled obligations under securities } \\
\text { supervision law can be enforced by BaFin } \\
\text { using these coercive measures adjusted to } \\
\text { the individual case. }\end{array}$ \\
\hline & Profession & $\S 36 \mathrm{KWG}, \S 70$ & According to $\S 36 \mathrm{KWG}$, BaFin can recall \\
\hline
\end{tabular}




\begin{tabular}{|l|l|l|l|}
\hline & al ban & $\begin{array}{l}\text { StGB } \\
\text { (Strafgesetzbuch, } \\
\text { Criminal code) }\end{array}$ & $\begin{array}{l}\text { managers of investment firms in case of } \\
\text { substantial breaches of regulation or Non- } \\
\text { compliance with the legal requirements for } \\
\text { managers. In case of a criminal sanction, } \\
\text { the criminal court can order a professional } \\
\text { ban for up to five years against the } \\
\text { respective person. }\end{array}$ \\
\hline
\end{tabular}

\section{Corrective action}

BaFin has power to impose a range of administrative remedies to compel compliance with the legislation it administers. These measures can be imposed without BaFin needing to seek orders from a court. Examples of these are powers to:

a. issue orders to regulated entities to stop or prevent violations of legislation or prevent developments that may endanger the safety of assets entrusted to an institution, or impair the provision of financial services;

b. issue instructions to the management of an institution, prohibit withdrawals or transfers from an account, and prohibit an institution from executing any other financial transactions;

(See Sections 6 and 6a KWG.)

c. issue orders to suspend trading in one or more financial instruments, including market trading;

d. after consultation with the Bundesbank, issue orders needed to eliminate or prevent undesirable developments that may harm financial market stability or undermine confidence in financial markets;

(See Sections 4 and s4a WpHG.)

e. impose conditions on or revoke a license;

(See Section 32(2) (license conditions) and Section 35(2) (revocation of license) KWG.)

f. compel an issuer to publish errors detected in its financial reports.

(See Section $37 q(2)$ WpHG.)

ESAs and stock exchange TSOs also have powers to suspend and discontinue trading, and to issue orders in response to irregularities and actual or threatened contraventions of relevant legislation. See for example, Section 3(5) of BörsG.

\section{Administrative penalties}

The legislation BaFin administers makes a clear distinction between administrative offences subject to administrative penalties (fines) and criminal offences such as insider trading (see especially Sections 38 and $39 \mathrm{WpHG}$ ). For some offences (such as market manipulation), a distinction is made between the elements of an offence that gives rise to a criminal penalty and those that amount to an administrative offence (see Sections 38(2) and 39(1) nos. 1 and 2).

BaFin is responsible for imposing fines and the public prosecutorial authorities for prosecution of criminal offences.

The Securities Trading Act (Sections 39 and $40 \mathrm{WpHG}$ ) gives BaFin power to impose administrative penalties up to $€ 1$ million for breaches of a broad range of administrative offences. A detailed scale of maximum penalties applicable to specific offences is set out in the legislation, with the largest maximum penalty being for market manipulation. 


\begin{tabular}{|c|c|}
\hline & 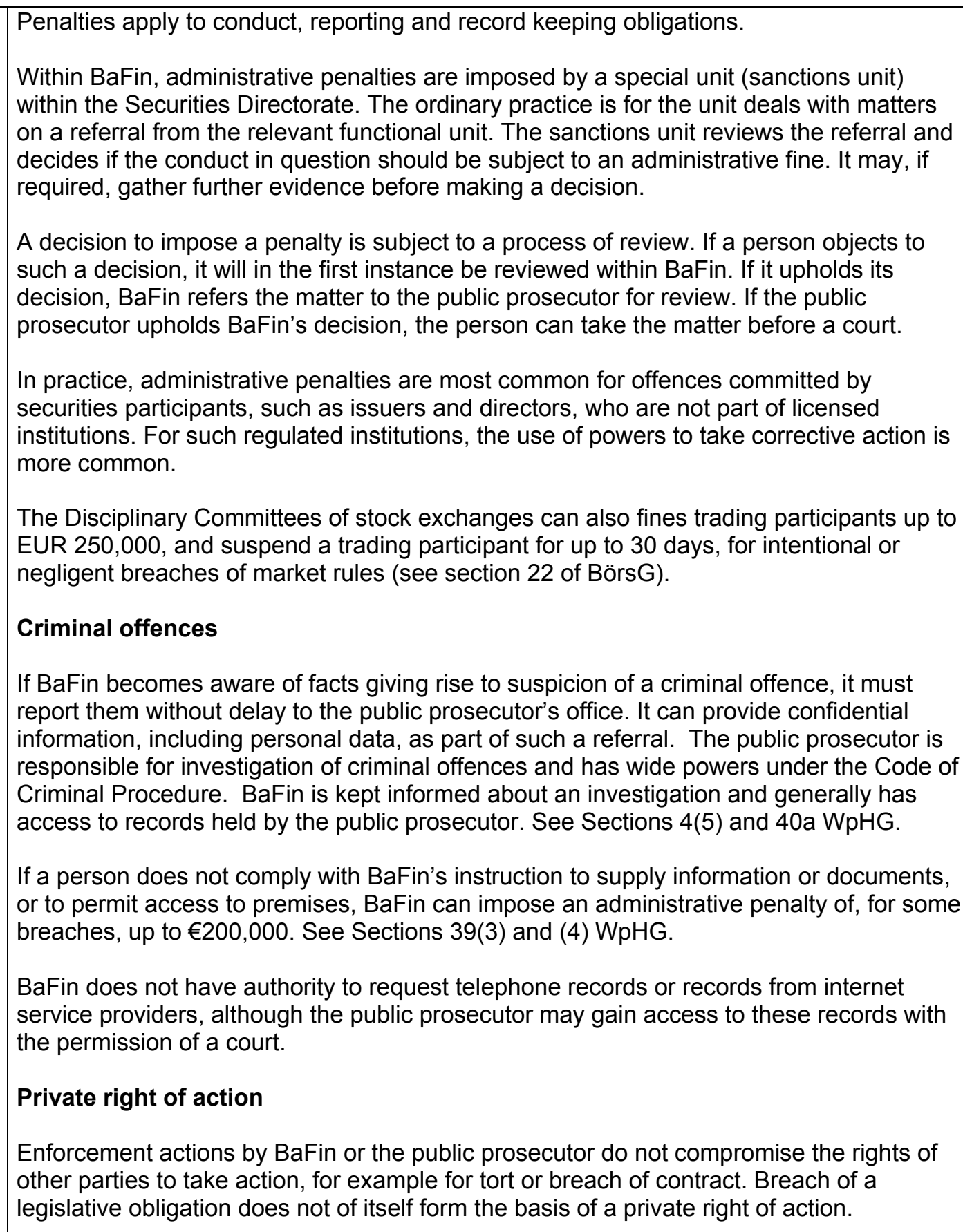 \\
\hline Assessment & Fully implemented \\
\hline Comments & $\begin{array}{l}\text { Within the system described above, a clear distinction is made between offences that } \\
\text { can be dealt with by administrative action by BaFin (corrective action and the imposition } \\
\text { of administrative penalties), and conduct giving rise to a criminal offence (the responsible } \\
\text { of the public prosecutor). BaFin's extensive powers for the role it plays, including for } \\
\text { gathering information and evidence to support a referral to the public prosecutor. }\end{array}$ \\
\hline Principle 10. & $\begin{array}{l}\text { The regulatory system should ensure an effective and credible use of inspection, } \\
\text { investigation, surveillance and enforcement powers and implementation of an effective } \\
\text { compliance program. }\end{array}$ \\
\hline
\end{tabular}




\begin{tabular}{|c|c|}
\hline Description & 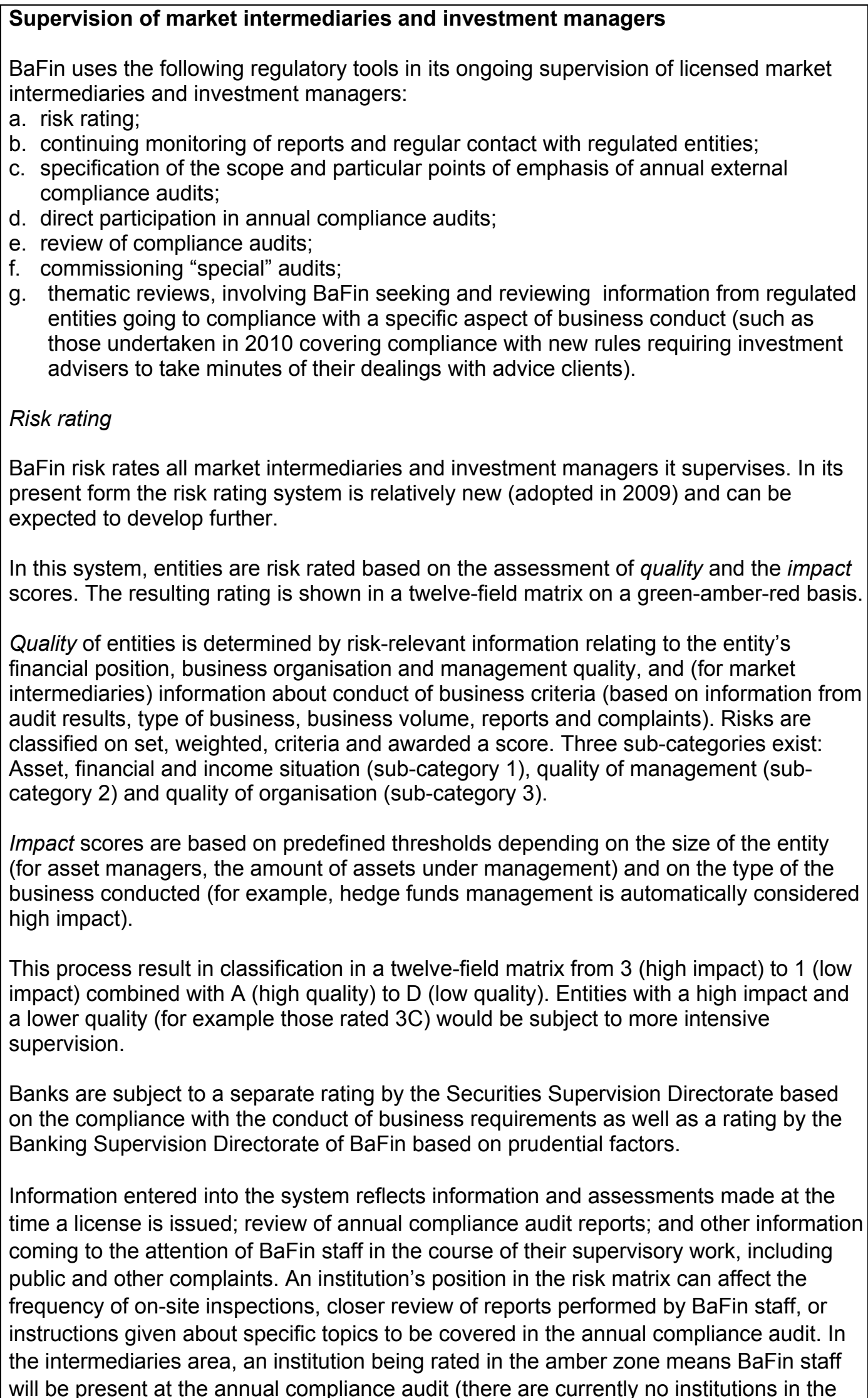 \\
\hline
\end{tabular}


red zone)

Risk Ratings of (Non-Bank )Financial Services Institutions for 2010

Financial service institutions
\begin{tabular}{|l|c|}
\hline & Total \\
\hline 1A & 227 \\
\hline 1B & 386 \\
\hline 1C & 43 \\
\hline 1D & 14 \\
\hline $2 \mathrm{~A}$ & 29 \\
\hline $2 \mathrm{~B}$ & 55 \\
\hline 2C & 13 \\
\hline $2 \mathrm{D}$ & 3 \\
\hline Total & 770 \\
\hline
\end{tabular}

Source: Information supplied to assessor

Investment Managers Risk Ratings, 2009

\begin{tabular}{|c|c|c|c|c|c|c|}
\hline \multirow{2}{*}{\multicolumn{2}{|c|}{$\begin{array}{l}\text { Investment } \\
\text { companies }\end{array}$}} & \multicolumn{4}{|c|}{ Quality of investment companies } & \multirow{2}{*}{ Total } \\
\hline & & A & B & c & D & \\
\hline \multirow{4}{*}{ 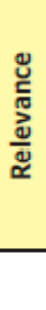 } & High & 25 & 7 & 0 & 0 & 32 \\
\hline & Medium & 21 & 2 & 0 & 0 & 23 \\
\hline & Low & 15 & 2 & 1 & 0 & 18 \\
\hline & Total & 61 & 11 & 1 & o & 73 \\
\hline
\end{tabular}

Source: 2009 BaFin Annual Report.

\section{Compliance audits}

BaFin makes extensive use of the work of regulated entities' external auditors in its supervision of both market intermediaries and investment managers and depositaries. The auditors of market intermediaries (see Section 36 of WpHG) and investment managers (see Sections 19f and 110a of InvG) must examine and report annually on whether an entity has complied with its reporting and conduct of business obligations. These audits (annual compliance audits) are all read by BaFin staff and are in effect the first line of compliance monitoring.

The nature scope of such compliance audits is set out in detail in the legislation. For market intermediaries see sections 4 to 6 of the Regulation on the Examination of 
Investment Services Enterprises pursuant to Section 36 of the Securities Trading Act (Wertpapierdienstleistungs Prüfungsverordnung, WpDPV); and for investment managers see the Investment Audit Reports Ordinance (Investment-Prüfungsberichtsverordnung InvPrüfbV) issued by BaFin. In addition, BaFin has the power to direct focus on key issues (Prüfungsschwerpunkte) for any audit, a power it exercises regularly both generally and in specific cases. For example, in $2010 \mathrm{BaFin}$ required auditors of banks to focus specially on the provision of investment advice and the performance of clients' accounts over a period of several years.

In addition to annual compliance audits, BaFin can commission "special" audits. These audits are in addition to the annual compliance audit and cover matters specified by BaFin. They are generally carried out by an auditor who is not the entity's normal external auditor.

BaFin staff participate both in some annual compliance audits, and routinely in special audits. In the BaFin context, on-site inspections ordinarily refer to inspection carried out jointly by an auditor (an institution's normal auditor or an auditor specially appointed by BaFin) and by BaFin staff.

For example, in 2010, the section supervising the 147 foreign and private banks under BaFin's supervision on business of conduct provisions participated in 26 audits.

As a general rule, major banks with significant relevance for the German market are visited regularly, most of them yearly. In all other cases, the selection of the entities that are visited by BaFin staff is met on the basis of the risk assessment. For these participations, BaFin staff participate in visits to banks' headquarters, and also foreign and domestic branches.

\section{Supervision of market intermediaries}

For (non-bank) financial services institutions, one person at BaFin is permanently allocated for the supervision of approximately 30 regulated entities. This gives supervisors an overview of the intermediaries under their supervision and the ability to assess the risk potential and issues of concern for these entities. As a general rule, supervisory contact with eight supervised entities per supervisor is foreseen in Department WA 3, ensuring that supervisors will have contact with each intermediary approximately every four years. The contacts are allocated on the basis of the risk assessment of the entity; therefore some intermediaries will be supervised more closely than others. Supervisory contacts will either be performed through participation in the external audits described above or via meetings with the intermediaries' management.

Deutsche Bundesbank holds yearly meetings with all financial services institutions (The Deutsche Bundesbank assists BaFin in the prudential supervision of banks and financial services institutions). The meetings serve to provide the participants with an update on the intermediary's activities. BaFin staff participates in these meetings when necessary to discuss regulatory breaches, new business models or other matters of interest. Although these meetings are primarily focused on prudential matters, other supervisory issues will also be discussed during these meetings when BaFin deems this necessary. When BaFin staff does not participate in the meetings, the Bundesbank will inform BaFin of the content and outcome of the meeting.

\section{Ongoing supervision of investment managers}

BaFin supervision of investment managers employs a range of techniques, including:

a. meetings with industry representative and auditors: BaFin meets with industry representatives (the representatives from relevant 


\begin{tabular}{|c|c|}
\hline & 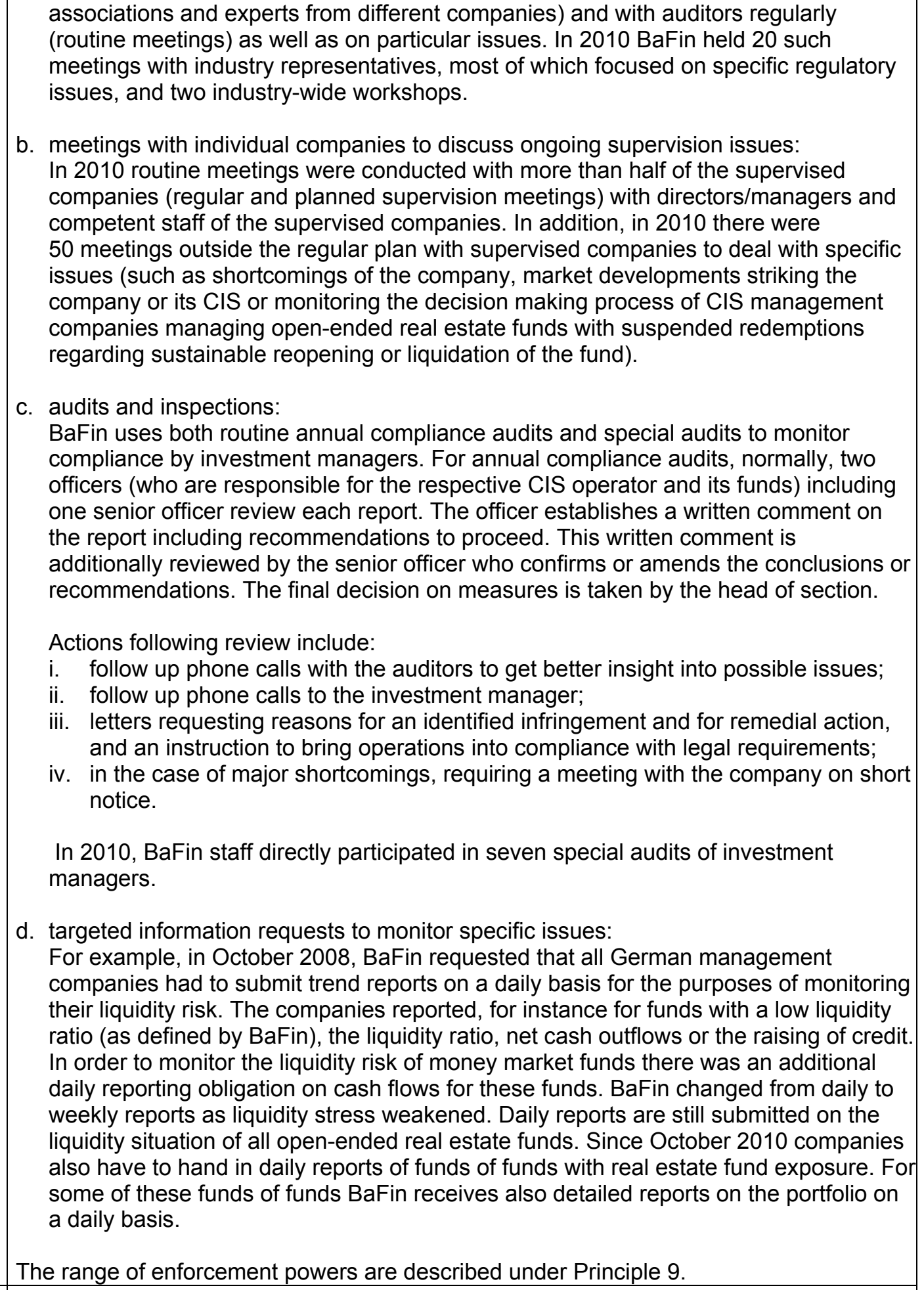 \\
\hline Assessment & Broadly implemented \\
\hline Comments & $\begin{array}{l}\text { BaFin's use of its enforcement powers is robust. It makes effective use of its investigative } \\
\text { and enforcement powers, both in relation to administrative sanctions and in meeting its } \\
\text { obligations to refer possible criminal conduct to the public prosecutorial authorities. The } \\
\text { assessor notes that administrative penalties are most commonly applied for breaches of } \\
\text { obligations by persons or entities that are not licensed financial institutions or investment }\end{array}$ \\
\hline
\end{tabular}


managers, such as issuers and their directors.

BaFin's monitoring of compliance by regulated entities-specifically CIS operators and licensed intermediaries - is heavily reliant on the analysis of incoming reports and other data, including annual compliance audits prepared by external auditors. It makes comparatively little use of on-site compliance inspections, whether on a routine basis or as part of a program that identifies potential emerging compliance risks resulting from changes in market conditions or behavior.

The use of annual compliance audits means that all regulated entities are subject to an annual audit specifically focused on compliance with legislative obligations. This, combined with BaFin's practice of examining all such audits, means all entities are subject to scrutiny each year.

On the other hand, it places a high level of reliance on the quality of the work carried out by auditors, and potentially lessens the direct presence of BaFin in the market place.

These comments are not meant to imply that monitoring performed by BaFin staff is solely desk-based. BaFin staff have direct contact with an institution during the processing of license applications or other registration procedures (such as for new funds formed by a CIS operator ), and BaFin staff are present during some annual compliance audits and at "special" audits required by BaFin either as part of a regular review program or to examine potential compliance problems. For example, in $2010 \mathrm{BaFin}$ commissioned 10 "regular review" audits and staff from the investment management department were present for some of those, and were present for some annual compliance audits; and intermediaries department staff were present for 76 annual audits and for one special audit. Staff from the Securities Directorate also participate in an annual supervisors conference, involving BMFs' bank supervisors and anti-money laundering staff and Bundesbank staff, to plan supervisory measures (including visits to banks during the annual external audit); and are present, along with bank supervisors and Bundesbank staff, at joint meetings with the senior management of major banks.

In the assessor's view, on balance, these measures do not result in BaFin having a sufficiently active presence in the marketplace, and risk its overall supervisory activity being too reliant on backward looking indicators. In particular, they may mean that BaFin is not in a position to detect at an early stage patterns of market conduct that have a potential adverse impact on regulated entities obligations, especially conduct obligations relating directly to investor protection issues. On balance, compliance with Principle 10 should be rated Broadly Implemented for the reasons described above.

These comments apply both where the type of regulated entity is relatively homogenous (such as the asset management sector, which is dominated by licensed banks), and where (as in the intermediaries sector) there is clear division between full service banking institutions and a more disparate population of nonbank institutions that do not hold client funds or assets.

This analysis affects compliance with a number of the IOSCO Principles, notably Principles 17 and 21.

It is recommended that BaFin review its approach by:

a. continuing to refine its approach to assessing and scoring risk; and 


\begin{tabular}{|c|c|}
\hline & $\begin{array}{l}\text { b. making more frequent use of on-site inspections to monitor compliance, both on a } \\
\text { risk score basis and for thematic issues such the selling practices of market } \\
\text { intermediaries. }\end{array}$ \\
\hline \multicolumn{2}{|r|}{ Principles for Cooperation in Regulation } \\
\hline Principle 11. & $\begin{array}{l}\text { The regulator should have authority to share both public and non-public information with } \\
\text { domestic and foreign counterparts. }\end{array}$ \\
\hline Description & $\begin{array}{l}\text { Domestic Cooperation } \\
\text { BaFin has obligations, and broad powers, to share public and non-public information with } \\
\text { other domestic regulators. } \\
\text { For securities market activity, the Securities Trading Act (Section } 6 \text { WpHG) requires } \\
\text { BaFin and other relevant domestic regulators (for example, ESAs, TSOs, and the Federal } \\
\text { Cartel Office) to communicate to each other findings and observations (including personal } \\
\text { data) that may be necessary for the performance of their functions. } \\
\text { The Banking Act (Section } 7 \text { KWG) requires BaFin and the Deutsche Bundesbank to } \\
\text { cooperate in the monitoring of regulated institutions (banks and financial services } \\
\text { institutions) and share data about licensed institutions. The legislative provisions are } \\
\text { complemented by a more detailed Guideline outlining how BaFin and the Bundesbank } \\
\text { work together in the supervision of regulated entities } \\
\text { Similar specific provisions apply in other legislation administered by BaFin, such the } \\
\text { Takeovers Act (Section } 7 \text { WpÜG). } \\
\text { These specific provisions are supplemented by a broad obligation under the } \\
\text { Administrative Procedures Act requiring administrative authorities to provide assistance } \\
\text { on request to other authorities (Section } 4 \text { VwVfG). } \\
\text { BaFin's foundations legislation also expressly recognizes that its function includes } \\
\text { cooperation with other bodies and persons in Germany and abroad (Section } 4 \text { FinDAG). } \\
\text { International cooperation } \\
\text { This framework is expressed in broad terms and permits the exchange of information } \\
\text { about authorization and licensing, findings from surveillance activities, observations about } \\
\text { market conditions and events, regulated entities and their clients, and issuers in capital } \\
\text { markets. } \\
\text { legislative provisions. BaFin has broad powers to share non-public information with } \\
\text { foreign regulators. ESAs are not authorized to provide information directly to foreign } \\
\text { regulators, and BaFin acts as the conduit for such information. }\end{array}$ \\
\hline
\end{tabular}

\footnotetext{
${ }^{9}$ See Guideline on carrying out and ensuring the quality of the ongoing monitoring of credit and financial services institutions by the Deutsche Bundesbank of February 21, 2008.
} 


\begin{tabular}{|c|c|}
\hline & 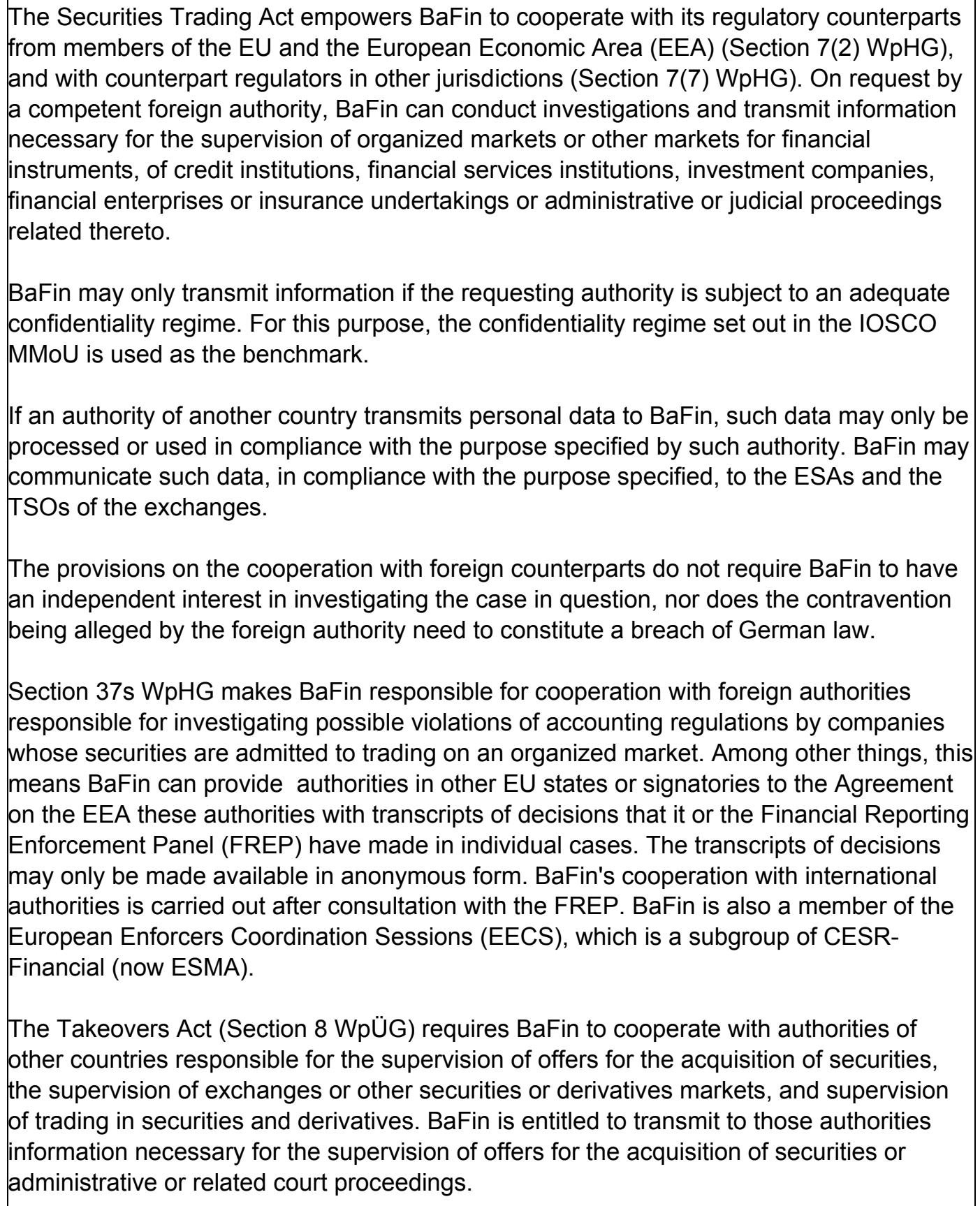 \\
\hline Assessment & Fully implemented \\
\hline \multicolumn{2}{|l|}{ Comments } \\
\hline Principle 12. & $\begin{array}{l}\text { Regulators should establish information sharing mechanisms that set out when and how } \\
\text { they will share both public and non-public information with their domestic and foreign } \\
\text { counterparts. }\end{array}$ \\
\hline Description & $\begin{array}{l}\text { As described under Principle 11, BaFin: } \\
\text { a. has obligations to co-operate with domestic regulators, including by exchanging } \\
\text { information with them. In addition, a detailed Guideline sets out cooperation } \\
\text { arrangements between BaFin and the Deutsche Bundesbank for the supervision of }\end{array}$ \\
\hline
\end{tabular}




\begin{tabular}{|c|c|}
\hline & $\begin{array}{l}\text { licensed banks and financial services institutions; } \\
\text { b. is a signatory to two multilateral MMoUs and numerous bilateral MoUs. } \\
\text { The obligation to provide mutual assistance domestically arises under constitutional law } \\
\text { and exists directly. No further arrangements (such as administrative agreements) for } \\
\text { information shared in this way with courts, other authorities of the federation, the Federal } \\
\text { States (Länder) or other corporations under public law, such as the exchange TSOs. } \\
\text { The Securities Trading Act provides that that BaFin may cooperate with competent } \\
\text { authorities of countries that are not members of the EU or the EEA and conclude } \\
\text { information-sharing agreements with them (Section } 7 \text { (7) WpHG)). BaFin has a } \\
\text { department specializing in concluding bilateral agreements on securities regulation as } \\
\text { well as banking and insurance supervision. } \\
\text { Enforcement related information } \\
\text { In } 2010, \text { BaFin made } 193 \text { requests for assistance to foreign authorities, and received } 69 \\
\text { on the basis of the IOSCO MMoU, the CESR MMoU and bilateral MoUs. } \\
\text { Confidentiality } \\
\text { Information supplied according to the arrangements described above is subject to rules } \\
\text { relating to confidentiality. These rules are contained in the legislation and also embodied } \\
\text { in the multilateral and other MOUs signed by BaFin. The rules provide that: } \\
\text { a. information supplied can only be used for the regulatory purpose for which it was } \\
\text { requested, including related judicial or administrative actions; } \\
\text { b. to the extent permitted by law, confidentiality is to be maintained; and } \\
\text { c. the receiving authority will provide advance notice to (and in some cases seek the } \\
\text { consent of) the receiving authority before making any disclosure to a third party. }\end{array}$ \\
\hline Assessment & Fully implemented \\
\hline Comments & \\
\hline Principle 13. & $\begin{array}{l}\text { The regulatory system should allow for assistance to be provided to foreign regulators } \\
\text { who need to make inquiries in the discharge of their functions and exercise of their } \\
\text { powers. }\end{array}$ \\
\hline Description & $\begin{array}{l}\text { As described under Principle } 11 \text { and 12, BaFin has powers to provide enter into } \\
\text { information sharing arrangements with foreign regulators. It has used those powers to } \\
\text { enter both MMOUs and bilateral MOUs on securities supervision with } 30 \text { countries } \\
\text { (including MOUs signed by BaFin's predecessor organizations). } \\
\text { BaFin can use the information gathering and investigation powers described under } \\
\text { Principles } 8-10 \text { to assist foreign regulators, and make use of information supplied to it by } \\
\text { regulated entities for this purpose. These include powers: } \\
\text { a. to obtain transaction records and records of fund and asset transfers associated with } \\
\text { those transactions; } \\
\text { b. to obtain records that identify the names of clients and other parties involved in } \\
\text { transactions; } \\
\text { c. details of transactions; }\end{array}$ \\
\hline
\end{tabular}




\begin{tabular}{|c|c|}
\hline & $\begin{array}{l}\text { d. beneficial owners/controllers of issuers (both listed and non-listed) and regulated } \\
\text { entities. } \\
\text { These powers can be used to provide assistance to foreign regulators secure compliance } \\
\text { with laws relating to insider trading and other forms of market abuse; the issue, offer or } \\
\text { sale of securities or derivatives; licensed market intermediaries, including collective } \\
\text { investment schemes and advisers; and markets, exchanges or clearing and settlement } \\
\text { facilities. } \\
\text { BaFin can also commence a formal investigation to secure information of this kind, } \\
\text { including where it has no direct regulatory interest in the activities the foreign regulator is } \\
\text { making enquiries about. } \\
\text { BaFin cannot normally approach a court for orders (such as the freezing of assets) } \\
\text { unless it is carrying out its own investigations, and even then it must demonstrate an } \\
\text { imminent risk. But it can and would in appropriate cases assist a foreign regulator to do } \\
\text { so, for example by providing advice on the German legal environment. In some } \\
\text { circumstances involving criminal activity, the public prosecutor can approach a court } \\
\text { asking for assets to be frozen. } \\
\text { Pursuant to the European Directive on supplementary supervision of financial } \\
\text { conglomerates (Financial Conglomerates Directive, 2002/87/EC), both the Banking Act } \\
\text { and the Insurance Act require BaFin to cooperate with the competent authorities in other } \\
\text { states of the EEA regarding the identification and supervision of financial conglomerates } \\
\text { (for example, see Banking Act sections 8a and 8b-there are matching provisions in the } \\
\text { Insurance Act). These provisions can be extended to cover conglomerates based in a } \\
\text { country outside the EEA that are subject to regulation equivalent to that applying within } \\
\text { the EEA. This has been done in the case of the regulatory regime administered by the } \\
\text { banking, securities and futures authorities in the USA, and the relevant Swiss authorities. }\end{array}$ \\
\hline Assessment & Fully implemented \\
\hline \multicolumn{2}{|l|}{ Comments } \\
\hline \multicolumn{2}{|r|}{ Principles for Issuers } \\
\hline Principle 14. & $\begin{array}{l}\text { There should be full, accurate and timely disclosure of financial results and other } \\
\text { information that is material to investors' decisions. }\end{array}$ \\
\hline Description & $\begin{array}{l}\text { The legislative framework provides a detailed framework for disclosure of information } \\
\text { material to the decision of investors in publicly offered and publicly traded securities. } \\
\text { BaFin has also issued a detailed Issuer Guideline which, among other things, covers } \\
\text { issuers' obligations for material event (ad hoc) disclosure and financial reporting. } \\
\text { For publicly offered securities, the framework consists of an initial disclosure (prospectus) } \\
\text { obligation; requirements for audited annual financial reports; half yearly reports; interim } \\
\text { management statements (required around the mid- point of the half yearly cycle); and } \\
\text { (for listed securities) material event reporting. } \\
\text { Public offers of securities }\end{array}$ \\
\hline
\end{tabular}


The Securities Prospectus Act (Wertpapierprospektgesetz, WpPG) gives effect to the European Prospectus Directive $;^{10}$ and the EC Prospectus Regulation ${ }^{11}$ applies of its own force in Germany, as in other member states of the EEA. The securities prospectus regime applies to the offer of securities to the public (defined in Section 2 no. 4 of WpPG) and the admission of securities to trading on a regulated market.

Exemptions from the prospectus requirements are in line with those under Prospectus Directive.

The broad principle is that no public offer can take place without a published prospectus and no prospectus may be published without prior approval by BaFin under Section 13(1) of the Securities Prospectus Act. Under Sections 14(1) and 14(3), the offeror or the person asking for admission to trading must publish the prospectus and inform BaFin immediately about the time and place of publication.

The required content of securities prospectuses is set out in Section 5(1) WpPG. The section requires the issuer to disclose in a securities prospectus all information which is necessary to enable investors to make an informed assessment of the assets and liabilities, financial position, profit and losses, and prospects of the issuer and of any guarantor, and of the rights attaching to such securities. This information must be presented in an easily analyzable and comprehensible form.

In addition, depending on the nature of the issuer and the type of securities that are to be publicly offered or listed on a regulated market, different annexes of the Prospectus Regulation apply.

The Prospectus Regulation includes, inter alia, a requirement for information about those who have a significant interest in a listed company or who seek control of a company. Other features of the European prospectus regime are reflected in the Securities Prospectus Act, including a requirement for a summary which briefly and non-technical language conveys the essential characteristics and risks associated with the issuer, any guarantor and the securities.

A securities prospectus must be made available to the public at least one day before the beginning of the offer to the public or the admission to trading (Section $14 \mathrm{WpPG}$ ). Publication in a permitted medium is required and in addition a copy of the prospectus must be made available free of charge to the public upon request.

Other related material, such as advertisements, must comply with Section $15 \mathrm{WpPG}$ which among other things requires all information concerning the public offer or the admission to trading on a regulated market to be consistent with information in the prospectus.

If information in a prospectus becomes materially out-of-date or otherwise inaccurate, the issuer must publish a supplementary prospectus (Section 16 WpPG), which also needs

\footnotetext{
${ }^{10}$ Directive 2003/71/EC of the European Parliament and the Council of 4 November 2003 on the prospectus to be published when securities are offered to the public or admitted to trading and amending Directive 2001/34/EC.

${ }^{11}$ Commission Regulation (EC) No 809/2004 of 29 April 2004 implementing Directive 2003/71/EC of the European Parliament and of the Council as regard to information contained in prospectuses as well as the format, incorporation by reference and publication of such prospectuses and dissemination of advertisements.
} 
BaFin approval.
Public offers of nonsecurities

For publicly offers of certain non-securities investments, a separate prospectus regime applies. The Act on the Prospectus for Securities Offered for Sale (WertpapierVerkaufsprospektgesetz - VerkProspG) and the Investment Prospectus Ordinance (Verordnung über Vermögensanlagen-Verkaufsprospekte - VermVerkProspV) establishes a similar prospectus regime for non-securities investment prospectuses.

This regime requires a published prospectus approved by BaFin for the public offer of non-securitized instruments that grant the investor participation in a company's profits (participation rights), for shares in assets held or managed by the issuer or a third-party on its own behalf for the account of a third party (trust assets), or for units in other closed-end funds that are offered to the public in Germany and are not represented by securities within the meaning of the WpPG (Section $8 f(1)$ VerkProspG). The Act also applies to registered bonds, for example the very large number of such bonds traded on the Stuttgart Stock Exchange (for which over 75,000 final term sheets were issued in 2010). The term "non-securities investments" covers for example shares in civil-law partnerships, general partnerships or limited partnerships interests, silent partnerships or participation rights.

Content requirements for prospectuses of this kind (Section $8 \mathrm{~g}$ of VerkProspG and related regulations), distribution arrangements (Section 9), and the requirement for supplementary disclosures (Section 11) are analogous to those applying to securities prospectuses under WpPG.

\section{BaFin practice}

Securities prospectuses are all reviewed by BaFin staff, with each prospectus examined by two staff members and, for IPOs, 3 staff members. Staffs check not only compliance with the legislative requirements but also test for comprehensibility, consistency and completeness. They bring to this function their own review of the issuer and have a specialist group within the prospectus area to review financial information in prospectuses. BaFin's decision on a prospectus is to be made within ten working days of its receipt; this time frame is extended to twenty working days for an IPO prospectus.

If a prospectus is defective, BaFin will ordinarily take corrective action by requiring correction of the prospectus or a supplementary prospectus, but it can also refuse to revoke approval of a prospectus and prohibit the public offer. It has broad powers to do so under Section $21 \mathrm{WpPG}$.

BaFin monitors the market to identify public offers made without and approved prospectus by sampling media such as newspapers and the internet. This applies to offers of securities and non-securities for which a prospectus is required.

The prospectus figures for 2009 and 2010 are:

\begin{tabular}{|l|l|c|c|}
\hline \multicolumn{1}{|c|}{ Item } & \multicolumn{1}{|c|}{ Comment } & $\mathbf{2 0 0 9}$ & $\mathbf{2 0 1 0}$ \\
\hline $\begin{array}{l}\text { Securities } \\
\text { prospectuses } \\
\text { approved }\end{array}$ & Includes supplements & $\mathbf{2 , 4 7 7}$ & $\mathbf{2 , 1 0 2}$ \\
\hline & & & \\
\hline & IPOs and capital increases & 88 & 65 \\
\hline & Derivative products & 148 & 166 \\
\hline & Bonds & 197 & 219 \\
\hline
\end{tabular}




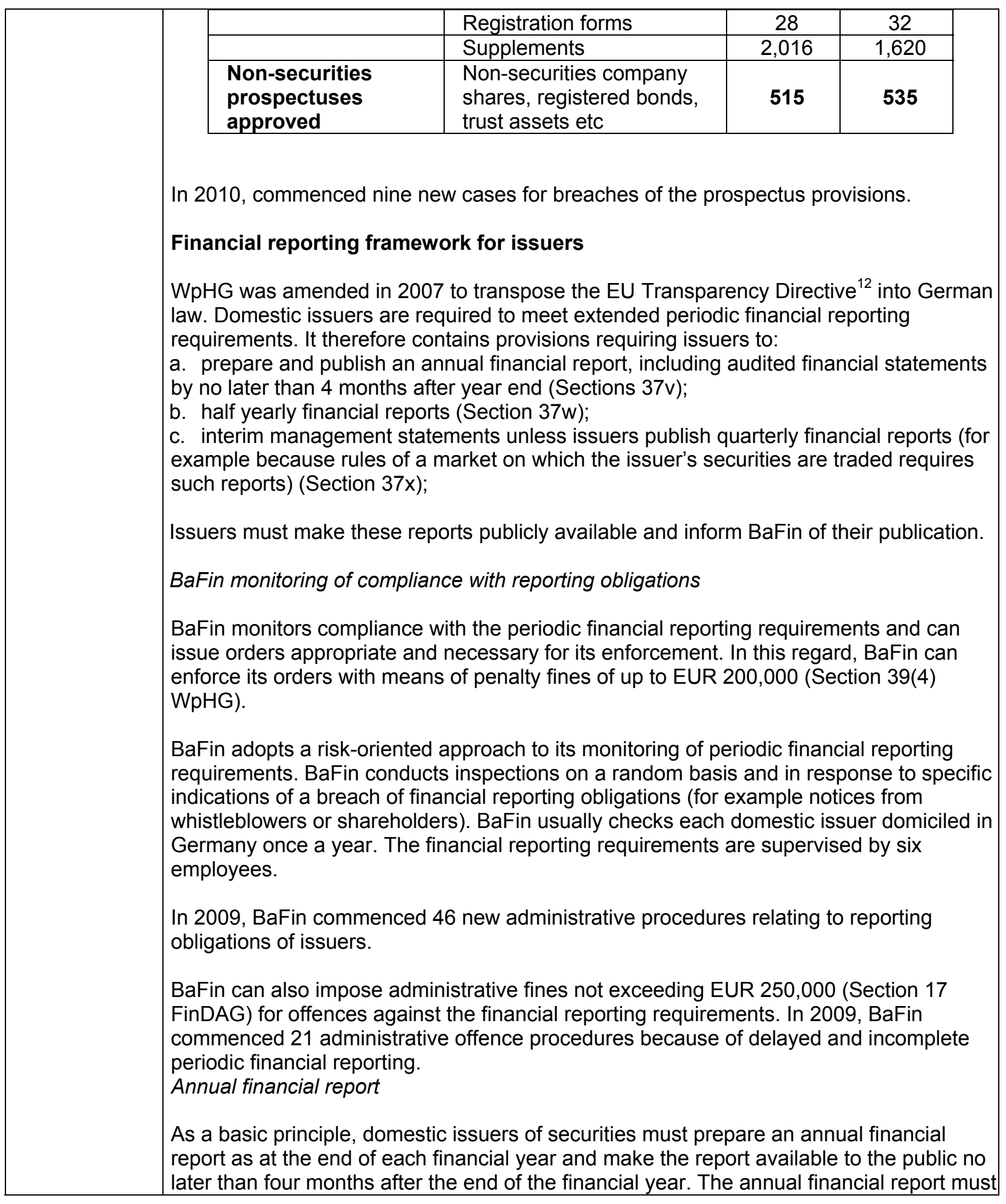

${ }^{12}$ Directive 2004/109/EC of the European Parliament and of the Council of December 15, 2004 on the harmonization of transparency requirements in relation to information about issuers whose securities are admitted to trading on a regulated market and amending Directive 2001/34/EC. 
include audited annual financial statements prepared in accordance with the national law of the member state in which the domestic issuer is registered, a management report and a compliance statement.

If a domestic issuer is obliged to prepare consolidated financial statements and a group management report, the annual financial report must also contain the audited consolidated financial statements prepared in accordance with IAS/IFRS, the group management report and a compliance statement concerning the consolidated financial statements and the group management report (Section 37y no. $1 \mathrm{WpHG}$ ).

\section{Material event disclosure}

Section $15 \mathrm{WpHG}$ requires an issuer of securities traded on a regulated market to publish any non-public material information that relates to the issuer or the securities. Material information is information about circumstances relating to one or more issuers of insider securities, or to the insider securities themselves, which are not publicly known and would be likely to have a significant impact on the market price of insider security if it became publicly known.

As well as making information of this kind public, the issuers must first ensure it is published on the company register and notify any regulated markets in Germany on which the financial instruments are traded, any market in Germany on which derivatives based on the securities are traded, and BaFin.

By Section $10 \mathrm{WpPG}$, issuers must also provide an annual disclosure to BaFin listing all information released by the issuer in last 12 months.

This general obligations is subject to an exemption that relieves the issuers of the obligation to publish such information as long as it is necessary to protect its legitimate interests, provided there is no reason to expect a misleading of the public and the issuer is able to ensure that the inside information will remain confidential. The issuer is obliged to notify BaFin regarding the grounds for exemption together with the notification, stating the time of the decision concerning the postponement of the publication. BaFin can check whether the decision not to publish information is within the permitted exception, and, if it is not, require immediate disclosure.

\section{Shareholder voting decisions}

The Stock Corporations Act (Aktiengesetz,AktG) requires disclosure on matters relating to shareholder voting decisions:

a. a shareholders' meeting must be convened a minimum of 30 days prior to the day of the meeting (Section 121);

b. the agenda, including board proposals on any issue, motions and nominations must be disclosed to the shareholders with the convening notice (Sections 121 and 124), as must motions and counter motions submitted by non-director shareholders, if submitted at least 14 days prior to the meeting (Section 126);

c. the same information must be given to credit institutions and associations of shareholders, which exercised voting rights at the previous shareholders meeting or demanded notice (Section 125).

Listed issuers must publish documents related to the shareholders' meeting on the company's internet site shortly after the convening of the shareholders' meeting (section 124a).

Details of any voting have to be published within seven days on the company's internet site (section $130(6)$ ). 
Enforcement of these provisions is a matter of private law, and BaFin does not have regulatory responsibility for compliance with them.

\section{Admissions of securities to a market}

Subject to limited exceptions, an approved prospectus must be issued for all securities admitted to trading on a regulated market (s1(1) WpPG and s32 BörsG). This prospectus must contain additional information about the market on which the securities are to be traded and about intermediaries providing market making functions. An issuer must also meet any other listing requirements, including minimum market value, free float and shareholder diversification requirements (Section 32 BörsG et seq., and BörsZulV).

Advertising or other information relating to an offer to the public of securities or to an admission to trading on a regulated market must comply with $\mathrm{s} 15 \mathrm{WpPG}$, including that all information concerning the offer or admission to trading must be consistent with that contained in the prospectus.

\section{Derivative markets}

The prospectus regime applies also to offers of derivatives. Annex XII Item 4 of the European Prospectus Regulation requires the issuer of derivative securities to provide information in the prospectus concerning the securities to be offered to the public or admitted to trading on a regulated market. This applies to financial instruments other than offers of share or debt instruments. These requirements include obligations to disclose:

a. a clear and comprehensive explanation to help investors understand how the value of their investment is affected by the value of the underlying instrument(s) if the securities' denomination or the minimum subscription amount is less than EUR 50,000 (Item 4.1.2.); b. a description of the rights, including any limitations of these, attached to the securities and procedure for the exercise of those rights (Item 4.1.7.);

c. information about the underlying (Item 4.2.).

The prospectus must also specify any market disruption or settlement disruption events that may affect the underlying as well as adjustment rules relating to the underlying.

The offeror or the person seeking admission to trading of the securities must also disclose any risks to enable the investor to assess the market risk associated with the securities (Annex XII Item 2 Prospectus Regulation).

\section{Financial leverage of issuers}

If securities prospectus rules apply to an issue or offer of derivative securities by market operators or intermediaries, the prospectus must include audited historical financial information of the issuer (Annex IV Items 13 et seq. Prospectus Regulation), and risk factors that may affect the issuer's ability to fulfill its obligations (Annex IV Item 4 Prospectus Regulation).

\section{Responsibility for information in regulated offer documents}

In both securities and non-securities prospectuses, the persons or entities responsible for the content must be clearly identified by name and function, and these persons must make a declaration that to the best of their knowledge the information in the prospectus is accurate and contain no material omissions. See s5(4) WpPG and s3 VermVerkProsV (Investment Prospectus Ordinance) 


\begin{tabular}{|c|c|}
\hline & $\begin{array}{l}\text { Derogations } \\
\text { Under Section } 8(1) \text { of WpPG, final pricing and issued amount information may be omitted } \\
\text { from a prospectus, subject to a requirement that the means of determining the pricing } \\
\text { and amount are disclosed, and a maximum price is stated. } \\
\text { BaFin has a more general power to permit information to be omitted in a prospectus if its } \\
\text { disclosure would be contrary to the issuer or seriously detrimental to the issuer or is } \\
\text { minor relevance (Section s8(2) WpPG). In practice, BaFin interprets the section narrowly } \\
\text { and has only permitted one such exception. } \\
\text { For secondary markets, the issuer has a power to withhold disclosure of ad hoc } \\
\text { information otherwise required to be disclosed if this is necessary to protect its legitimate } \\
\text { interests, provided it would not involve misleading the public and the information remains } \\
\text { confidential: s15(1) WpHG. This exception is in line with the Transparency Directive, and } \\
\text { requires BaFin approval. } \\
\text { Cross border issues } \\
\text { The European Prospectus Directive (Recital } 22 \text { and Art } 7(3) \text { ) explicitly refers to and } \\
\text { incorporates IOSCO standards for cross-border offerings and initial listings by foreign } \\
\text { issues. }\end{array}$ \\
\hline Assessment & Fully implemented \\
\hline Comments & \\
\hline Principle 15. & Holders of securities in a company should be treated in a fair and equitable manner. \\
\hline Description & $\begin{array}{l}\text { Rights and equitable treatment of shareholders } \\
\text { The Stock Corporation Act (Aktiengesetz, AktG) provides the overall regulatory } \\
\text { framework and legal infrastructure for publicly traded corporations, supplemented by } \\
\text { specific provisions in the WpPG. AktG (and the legislation relating to corporate mergers } \\
\text { and reorganisation) was amended in } 2009 \text { to implement the European Shareholders } \\
\text { Rights Directive. }{ }^{13} \text { More specific legislation deals with takeovers and other changes of } \\
\text { control. } \\
\text { AktG provides that: } \\
\text { a. all shareholders are to be treated equally under equivalent circumstances (sections } \\
\text { 53a and 134), and all shareholders with the same class of shares are to be treated } \\
\text { equally (Sections } 12,53 a \text { and } 179 \text { ); } \\
\text { b. shareholders are entitled to vote on } \\
\text { 1. the appointment of members of the supervisory board (other than employee } \\
\text { representatives under the German co-determination system); } \\
\text { 2. the appropriation of distributable profits; } \\
\text { 3. the ratification of the acts of the members of the management board and the } \\
\text { supervisory board; } \\
\text { 4. the appointment of the auditor; } \\
\text { 5. amendments to the articles; } \\
\text { 6. measures to increase or reduce the share capital; } \\
\text { 7. the appointment of auditors for the examination of matters in connection with the }\end{array}$ \\
\hline
\end{tabular}

${ }^{13} 2007 / 36 / E C$. 


\begin{tabular}{|c|}
\hline 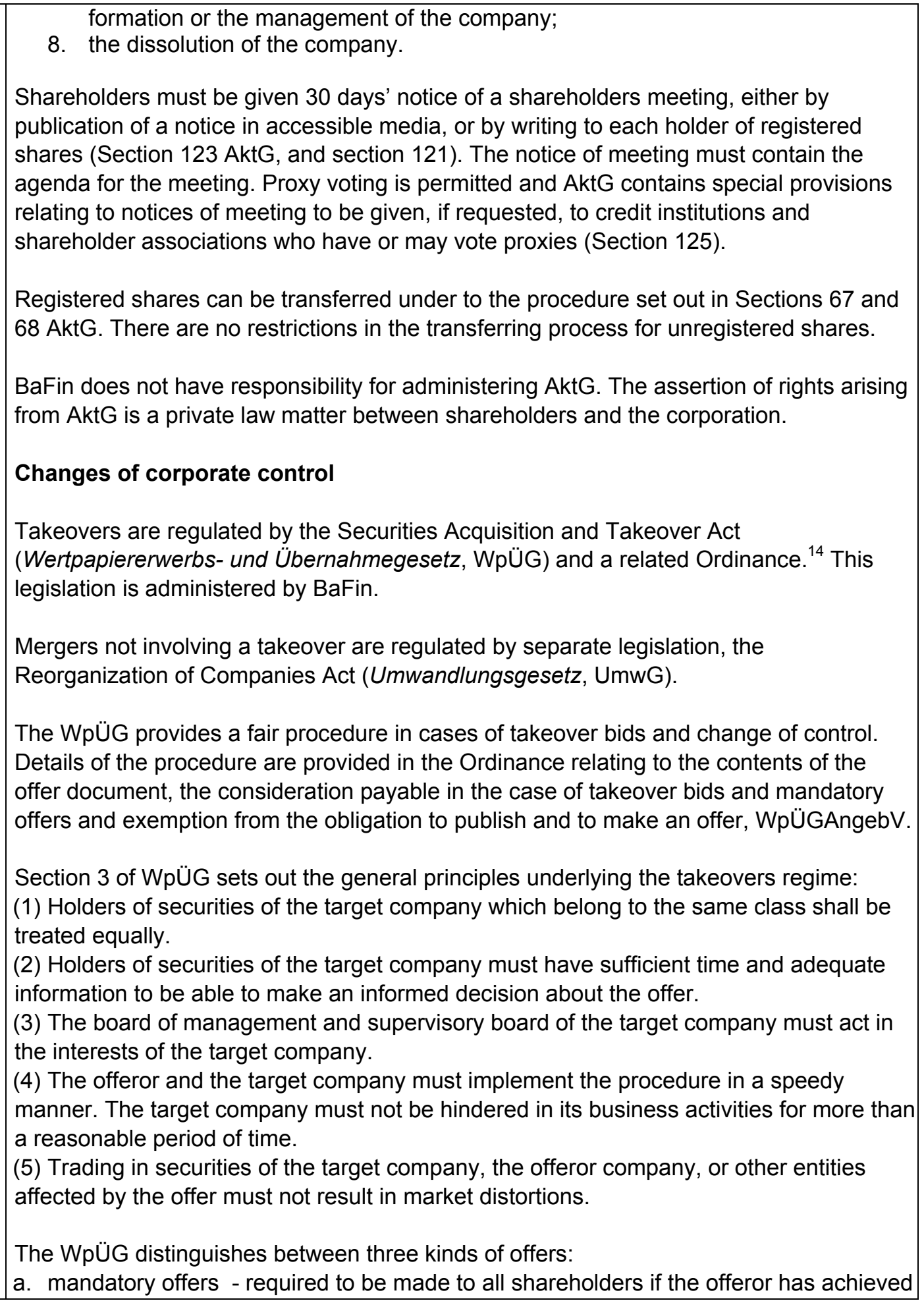 \\
\hline
\end{tabular}

${ }^{14}$ Verordnung über den Inhalt der Angebotsunterlage, die Gegenleistung bei Übernahmeangeboten und Pflichtangeboten und die Befreiung von der Verpflichtung zur Veröffentlichung und zur Abgabe eines Angebots, (WpÜGAngebV). 
control of a target company (at least 30 percent of the voting rights of a target company, either resulting from direct shareholdings or by attribution of voting rights);

b. voluntary offers-where the offeror is attempting to achieve control.

The consideration paid to the shareholders in mandatory offers and voluntary offers is subject to a minimum price rule by Section 31 WpÜG and Sections 3-6 of WpÜGAngebV. Section 31 provides that the offeror must offer the shareholders of the target company adequate consideration. In determining the adequate consideration, the average stock exchange price of the shares of the target company and acquisitions of shares of the target company by the offeror, persons acting in concert with him, or subsidiaries of the latter, shall generally be taken into account. The minimum price must be at least equal to the value of the highest consideration paid or agreed by the offeror, a person acting in concert with the offeror or any of their subsidiaries, to acquire shares in the target company within the last six months prior to publication of the offer.

c. simple offers for acquisition-where the offeror seeks to acquire securities without gaining control, or to build on a pre-existing position control. The general principle of the equal treatment of all shareholders applies to simple offers for acquisition as well, but the minimum price rules do not apply.

\section{Disclosure}

Shareholders to whom a takeover offer is made must have at least four weeks to consider the offer (section 16 WpÜG). Section 11 WpÜG and Section 2 WpÜGAngebV require adequate information to be given to offerees, including details about the type and amount of consideration offered, valuation methods used, funds available to the offeror, the offeror's intentions for the target company, the offeror's existing shareholdings and so on.

The management board and the supervisory board of the target company must issue a statement regarding the offer (Section $27 \mathrm{WpÜG)}$ ). They are also prohibited from taking action that may frustrate the offer (Section 33).

BaFin monitors compliance with these disclosure obligations and its approval is required before the offer document is sent to shareholders. Non-compliance with the takeover legislation, especially the obligation to announce an offer or to produce a complying offer document, can result in BaFin ordering the suspension of the offer (section $15 \mathrm{WpÜG),}$ and expose the non-complying party to administrative penalties of up to EUR 1 million (section 60 WpÜG).

BaFin takeover activity in 2009 and 2010 is summarized below:

\section{Corporate Takeovers}

\begin{tabular}{|l|l|l|l|}
\hline Item & Comment & $\mathbf{2 0 0 9}$ & $\mathbf{2 0 1 0}$ \\
\hline $\begin{array}{l}\text { Offers } \\
\text { approved }\end{array}$ & $\mathbf{1 8}$ & $\mathbf{2 3}$ \\
\hline & Acquisition offers & 3 & 3 \\
\hline & Takeover bids & 8 & 11 \\
\hline & Mandatory offers & 7 & 9 \\
\hline
\end{tabular}




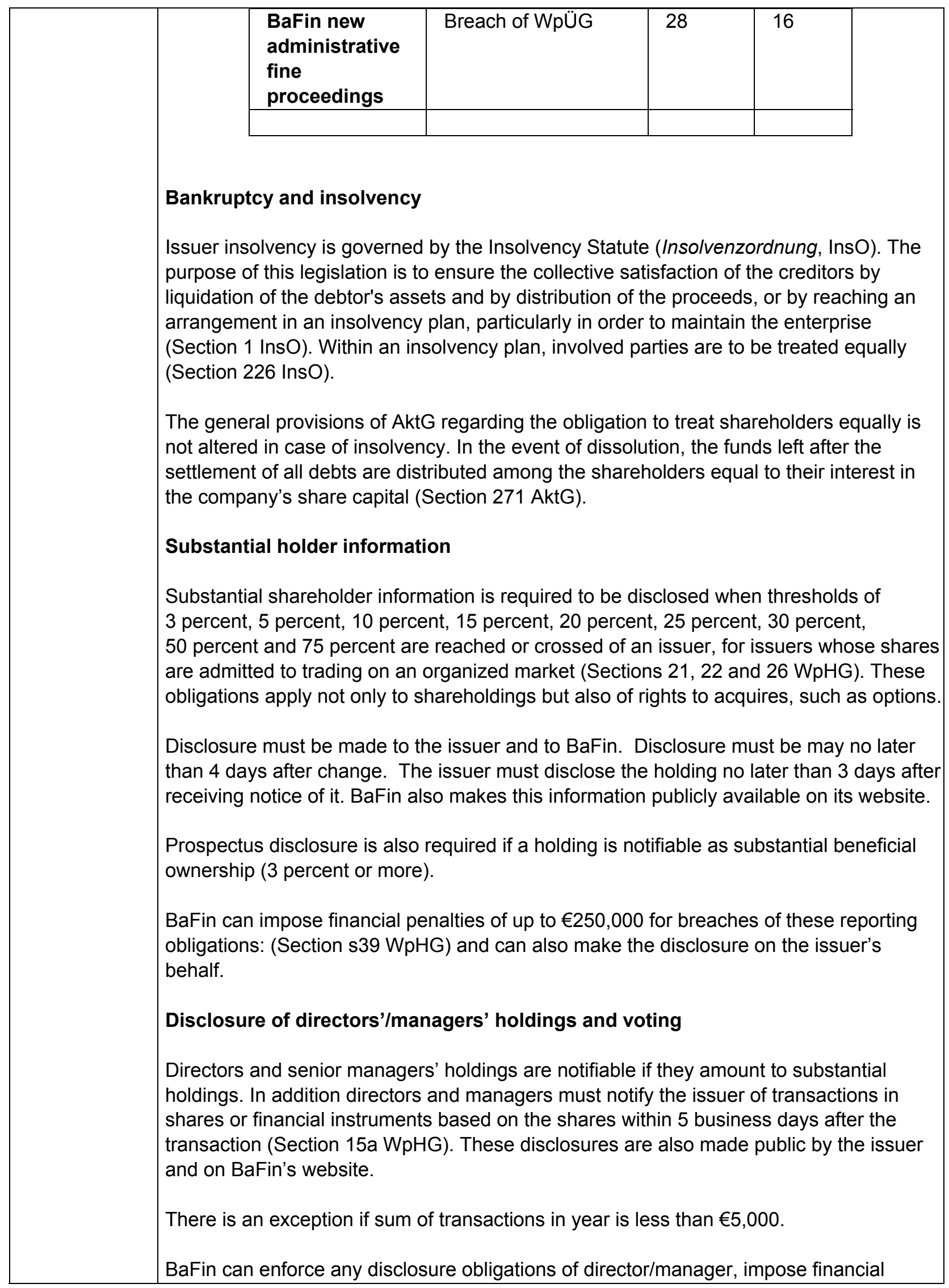




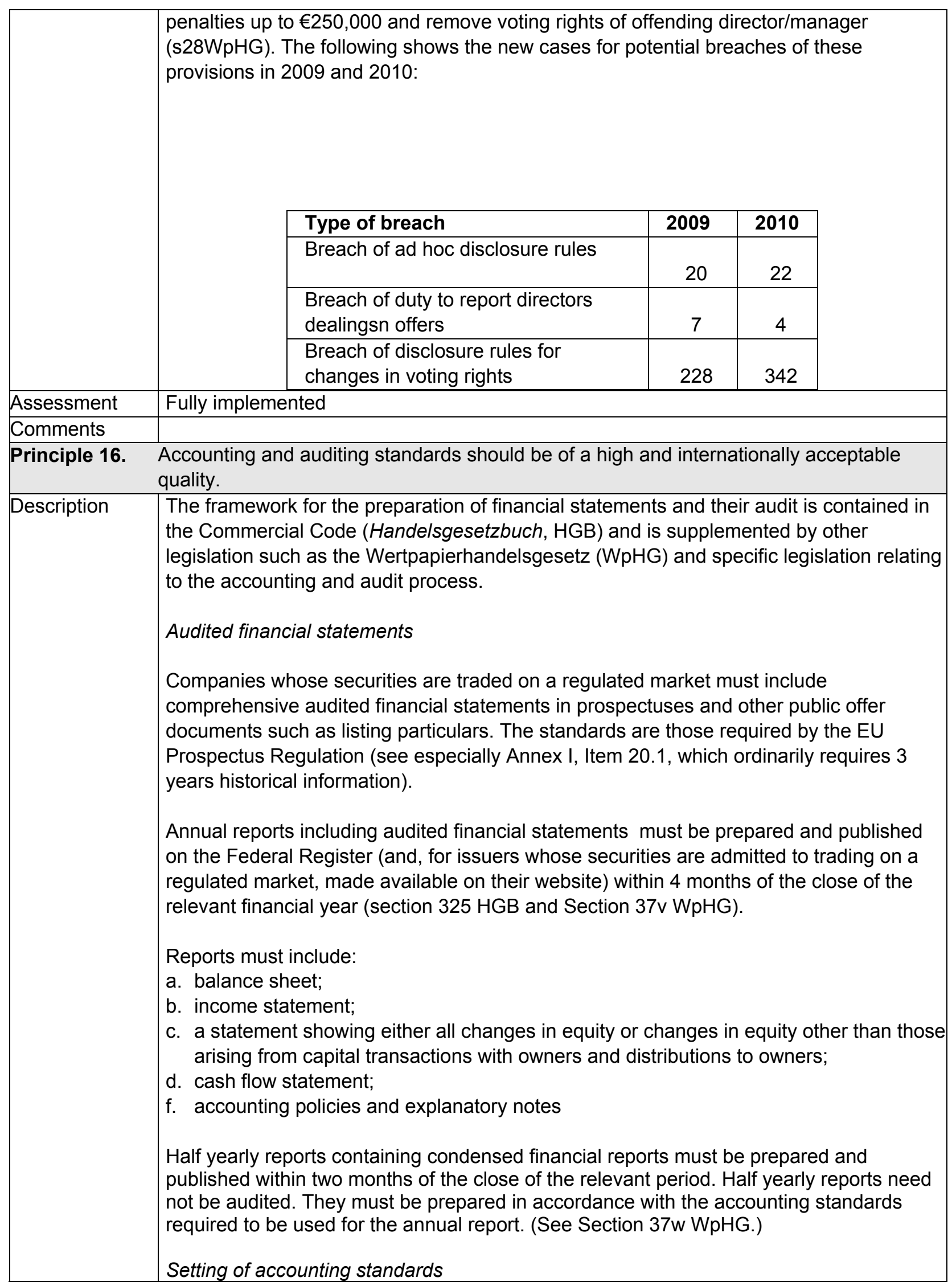


Financial statements contained in financial reports must be prepared in accordance with domestic accounting standards, IFRS or accounting standards recognize as equivalent to IFRS.

IFRS is required for the consolidated financial statements of companies whose securities are admitted to trading on a regulated market. For the financial statements of other companies, IFRS standards may be used for information purposes but for profit distribution, taxation and financial services supervision purposes German domestic standards must be used.

The requirements for German domestic standards, including presentation standards, are set out in the Commercial Code (HGB) and regulations made under that Act. These standards accord with relevant European directives. Elaborations of these standards and guidance on applying them are provided by the German Accounting Standards Committee (Deutscher Standardisierungsrat, DSR), the standard setting arm of the German Accounting Standards Committee (DSRC). DSRC is a private institution contracted by the Federal Ministry of Justice to play this role. One standards are published by the Ministry, they are taken represent German Proper Accounting Principles for consolidated financial reporting. DSR is also responsible for interpretation of standards, in conjunction with IASB IC for IFRS.

Issuers may also use international standards recognized for the preparation of financial statements required under the German securities legislation.

\section{Setting of auditing standards}

Audits of required financial statements are undertaken by an auditor registered by the Chamber of Auditors under the Public Auditors Act (Gesetz über eine Berufsordnung der Wirtschaftsprüfer, WPO). Auditors are appointed by the shareholders. Legislation (section 317(5) HGB provides that audit standards adopted by the European Commission apply to statutory audits (such as those for listed issuers). To date there are no such standards and the audit standards in use are those issued by the Institute of Auditors (Institut der Wirtschaftsprüfer in Deutschland e.V., IDW).

\section{Auditor independence}

WPO imposes professional obligations on auditors, including independence; and HGB prohibits the auditor from acting in specified circumstances. (See Section 43 WPO; and Section 319ff HGB.).

\section{Compliance monitoring}

Issuers' compliance with their obligations in the preparation of financial statements is subject to review at two levels.

The Financial Reporting Enforcement Panel (FREP, Deutsche Prüfstelle für Rechnungslegung (DRP) - a private body) reviews financial statements:

a. breaches of the legislation or standards are suspected;

b. at BaFin's request;

c. as part of a random sample (under principles agreed with the Federal Ministries of Justice and Finance, sampling involves both risk-based and statistically random sampling techniques)..

FREP carries out round 120-130 such reviews each year, 90 percent of which are selected through the random sample process. 


\begin{tabular}{|c|c|}
\hline & $\begin{array}{l}\text { FREP has no enforcement powers, so BaFin reviews compliance by issuers with } \\
\text { financial statement obligations either on referral of a matter from FREP or if it is } \\
\text { concerned about the review carried out by FREP. BaFin ordinarily requires issuers to } \\
\text { publish the errors established by BaFin or FREP. (See section } 37 q \text { WpHG.) } \\
\text { Non-German companies are also subject to the enforcement procedure if their securities } \\
\text { are admitted to trading on the regulated market of a German stock exchange. (See } \\
\text { Section } 37 n \text { WpHG) } \\
\text { To } 1 \text { July } 2009,960 \text { companies have been subject to this enforcement process - } 815 \\
\text { German and } 145 \text { non-German companies. BaFin's priority is to ensure that the market } \\
\text { has reliable information in financial statements. } \\
\text { Auditors are required by legislation to submit to peer reviews and are subject to } \\
\text { monitoring and disciplinary action by the Chamber of Auditors (Wirtschaftsprüferkammer, } \\
\text { WPK). }{ }^{15} \text { The Auditor Oversight Commission (Abschlussprüferaufsichtskommission - } \\
\text { APAK) is responsible for the public supervision of the WPK, including its oversight and } \\
\text { disciplinary activities. APAK operates according to published rules of procedure } \\
\text { approved by the Federal Ministry of Economics and Labor. The APAK is also responsible } \\
\text { for cross-border co-operation concerning statutory auditor. (See sections } 57 a ; \text {; } 61 \text { a; } \\
\text { s66a and s66b WPO.) }\end{array}$ \\
\hline Assessment & Fully implemented \\
\hline Comments & \\
\hline \multicolumn{2}{|r|}{ Principles for Collective Investment Schemes } \\
\hline Principle 17. & $\begin{array}{l}\text { The regulatory system should set standards for the eligibility and the regulation of those } \\
\text { who wish to market or operate a collective investment scheme. }\end{array}$ \\
\hline Description & $\begin{array}{l}\text { Outline of regulatory regime } \\
\text { CIS activity is regulated primarily through the Investment Act (Investmentgesetz, InvG). } \\
\text { This legislation regulates diversified, open-ended funds. It covers German asset } \\
\text { management companies and investment stock corporations, funds, investments that can } \\
\text { be held by funds, and public offers of foreign funds in Germany. The legislation classifies } \\
\text { funds according to underlying asset classes, and has special provisions dealing with } \\
\text { (among others) real estate funds and hedge funds. } \\
\text { Undiversified funds, or closed-end funds that do not offer redemption facilities, are not } \\
\text { regulated through InvG. } \\
\text { InvG provisions are supplemented by other specific legislation. For example, the } \\
\text { Derivative Regulation (Derivateverordnung, DerivateV) regulates fund investment in } \\
\text { derivatives (by imposing additional rules for risk management systems, market risk } \\
\text { assessment, stress tests and investment in structured products); and other regulations } \\
\text { deal with the audit of investment funds (InvPrüfbV }{ }^{16} \text { ) and accounting and valuation for } \\
\text { investment funds including the content and presentation of annual reports (InvRBV }{ }^{17} \text { ). }\end{array}$ \\
\hline
\end{tabular}

\footnotetext{
${ }^{15}$ Amendments to the WPO implemented Article 29 of Directive 2006/43/EC on statutory audit and the recommendation on external quality assurance for statutory auditors and audit firms auditing public interest entities (2008/362/EC).

${ }^{16}$ Verordnung über die Inhalte der Prüfungsberichte für Kapitalanlagegesellschaften, Investmentaktiengesellschaften und Sondervermögen (Investmentprüfungsberichtsverordnung).
} 
Asset management companies must hold a license under the InvG.

The legislative scheme currently reflects the European UCITS III directive. Legislation to implement UCITS IV is come into effect by 30 June 2011.

BaFin has responsibility for administering this legislative framework.

The regulatory framework applies in full to retail investment funds. The regulatory framework applies also to non-retail funds but aspects of the regime, such as the approval of fund rules, the prospectus provisions and some investment restrictions do not apply, or (as in the case of investment restrictions) do not apply if the investors elect to have them not apply.

BaFin has issued a number of circulars, including a circular (5/2010 (WA)) on the minimum requirements for the risk management of asset management companies and investment stock companies (Mindestanforderungen an das Risikomanagement für Investmentgesellschaften, InvMaRisk). The circular sets out minimum requirements for risk management systems, which require management companies and investment companies to identify, measure, manage and monitor on a continuous basis all risks relevant to the funds they manage.

The funds management industry, in conjunction with BaFin has also developed model fund rules and model prospectuses for use by the industry.

\section{CIS activity subject to authorization}

Marketing a CIS

A person is exempt from the need to hold a license as an investment adviser, an investment broker or contract broker under the Banking Act if they provide these services only in relation to CIS unit admitted for marketing in Germany and they do not hold customer funds (section 2(6) no $8 \mathrm{KWG}$ and section $2 \mathrm{a}(1)$ no $7 \mathrm{WpHG}$ ). In practice this means that the Banking Act licensing provisions only apply to persons who carry on an investment advice, investment broking or contract broking business in addition to their CIS marketing activities, or who act as an agent of the CIS operator (whose license will make it responsible for the conduct of the person).

Intermediaries who fall within the exception outlined above are required to hold an authorization under the German Industrial Code (Gewerbeordnung, GewO), a process involving personal integrity and financial checks. In addition, they must comply with regulations ${ }^{18}$ relating to their conduct, including an explicit obligation to provide a client with access to the prospectus required by InvG. Compliance with these provisions is monitored not by BaFin, but by relevant State authorities.

\footnotetext{
${ }^{17}$ Verordnung über Inhalt, Umfang und Darstellung von Jahres-, Halbjahres-, Zwischen-, Auflösungs- und Liquidationsberichten von Sondervermögen und der Jahresabschlüsse und Lageberichte, Halbjahres-, Zwischen-, Auflösungs- und Liquidationsberichte von Investmentaktiengesellschaften sowie die Bewertung der dem Investmentvermögen zugehörigen Vermögensgegenstände (Investment- Rechnungslegungs- und Bewertungsverordnung)

${ }^{18}$ The relevant regulation is a regulation on the obligations commercial brokers and agents, including investment brokers and advisers, and property developers (Bauträger- und Marklerverordnung, BMV).
} 
Operating a CIS

CIS operations may be carried out through an asset management company or an investment stock corporation. In both cases, operators must be authorized under InvG (section s7 InvG).

Before operators can be licensed, they must meet eligibility criteria including for:

a. the integrity of managers and holders of qualified participating interests (more than 10 percent of shares in the management company);

b. the professional competence of managers;

c. business organization, internal controls and risk management systems; and

d. minimum initial capital $(€ 300,000)$.

International cooperation

Under the legislation, UCITS compliant schemes can be marketed within the EU and the EEA by the holder of a passport issued by BaFin. UCITS schemes based elsewhere in the EU can be marketed in Germany but the operator must notify BaFin. Offering schemes in Germany from countries outside the EU can be done if BaFin is satisfied about home jurisdiction regulation and cooperation from the home regulator.

As well as the general information sharing and cooperation arrangement described in Principles 11-13, the investment legislation specifically requires BaFin to cooperate with relevant authorities in the EU and the EEA, and empowers it to enter information sharing arrangements with third country regulators.

Sanctions for non-compliance

BaFin has extensive powers to gather information and obtain evidence about $\mathrm{CIS}$ activity.

Operating a CIS without a license is a breach of the legislation exposing the operator to criminal sanctions. BaFin can also require immediate cessation of business activities.

BaFin can sanction breaches by licensees of obligations under the investment legislation by imposing administrative fines (Section 143 of InvG), revoking the operator's license (Section 17) and demanding dismissal of managers (section 17a). Section 5 authorizes BaFin to issue all orders deemed necessary and appropriate to ensure the operations of an asset management company or an investment stock company comply with the Act.

CIS operators are under a general obligation to act solely in the interest of investors, and a specific duty to minimize conflicts of interest. Operators' conduct of business is also covered by an industry code developed in association with BaFin and intended to flesh out the general obligation.

Outsourcing of functions is permitted, but subject to rules to ensure it does not detract from investor protection or effective supervision. Operators remain accountable to BaFin for outsourced functions.

\section{BaFin practice}

The techniques BaFin uses for monitoring compliance by asset management companies 


\begin{tabular}{|c|c|}
\hline & $\begin{array}{l}\text { are described under Principle } 10 . \\
\text { In } 2010, \mathrm{BaFin} \text { carried out } 10 \text { on-site inspections. All of them were regular on-site } \\
\text { inspections, which take place after a specific period of time according to the risk } \\
\text { assessment of the investment companies. Inspections were carried out by auditors by } \\
\text { order of BaFin, in some cases the auditors were accompanied by BaFin-staff. In three } \\
\text { cases, the audit is not yet completed. The other seven inspections identified minor or } \\
\text { middle organizational shortcomings. The most severe deficiency (insufficient outsourcing } \\
\text { controls) is being followed up control by BaFin. There were no on-the-spot inspections in } \\
2010 \text {. No formal sanctions (like a fine or the removal of a director) were imposed on a } \\
\text { CIS operator. } \\
\text { In roughly } 300 \text { cases management companies have been asked to modify prospectuses. } \\
\text { There were no criminal cases arising from the activity of a CIS. }\end{array}$ \\
\hline Assessment & Partly implemented \\
\hline Comments & 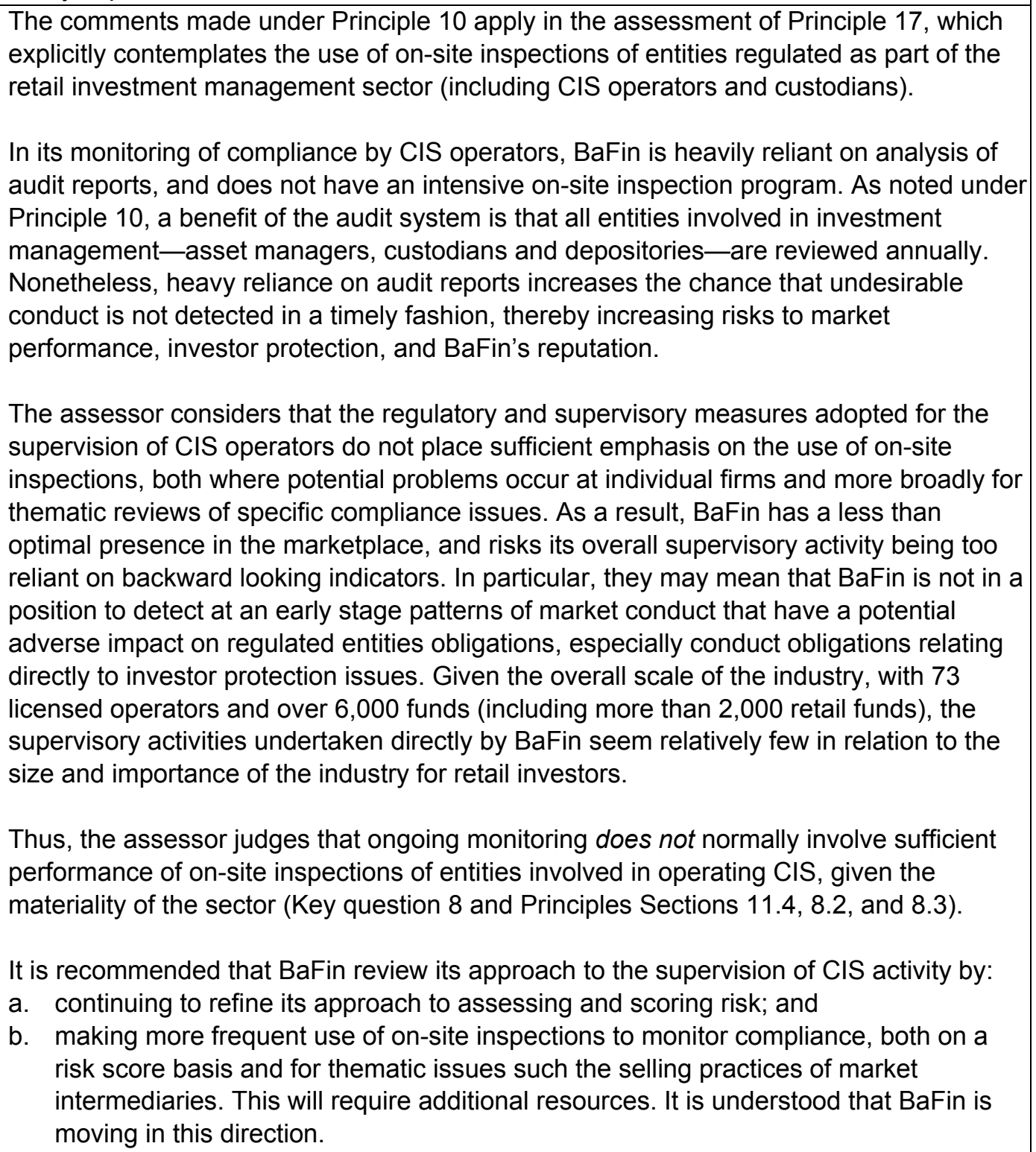 \\
\hline
\end{tabular}




\begin{tabular}{|c|c|}
\hline Principle 18. & $\begin{array}{l}\text { The regulatory system should provide for rules governing the legal form and structure of } \\
\text { collective investment schemes and the segregation and protection of client assets. }\end{array}$ \\
\hline Description & $\begin{array}{l}\text { For each CIS, fund rules are required which set out the legal relations between investors } \\
\text { and CIS operator, the rights of investors (including redemption rights), and details about } \\
\text { the fund. For retail funds, these rules and any changes to them require BaFin approval } \\
\text { (except for rules setting fees and charges). Fund rules and amendments to them must be } \\
\text { published in the Federal Gazette. } \\
\text { Fund assets must be segregated from the assets of the operator and held by a licensed } \\
\text { custodian bank the appointment or replacement of which requires BaFin approval. This } \\
\text { custody function is treated for regulatory purposes as part of the custodian's banking } \\
\text { business. If the CIS operator is an investment stock corporation, the legislation prohibits } \\
\text { transactions between managers and the CIS. } \\
\text { As well as CIS operators being subject to the general commercial law relating to books } \\
\text { and record keeping, the investment legislation requires specifically that transaction } \\
\text { records be kept. } \\
\text { The requirement to keep a register of holders of units currently only applies to registered } \\
\text { certificates (Section } 33 \text { (1) InvG) not to bearer certificates. This will change under the } \\
\text { legislation implementing UCITS IV which will take effect in mid } 2011 . \\
\text { An annual audit is required for each scheme, the CIS operator and the relevant } \\
\text { custodian. The Investment Audit Reports Ordinance (Verordnung über die Inhalte der } \\
\text { Prüfungsberichte für Kapitalanlagegesellschaften, Investmentaktiengesellschaften und } \\
\text { Sondervermögen, InvPrüfV) codifies the applies to these audits. } \\
\text { BaFin reviews all audit reports for retail CIS, including reports on management } \\
\text { companies, individual funds and custodians. } \\
\text { InvG (Sections } 38-40 \text { and } 44 \text { ) creates a process for orderly winding up of a CIS business } \\
\text { if its operator voluntarily ceases to act or through insolvency. If the operator's right to } \\
\text { manage ceases, the assets of the fund pass to the custodian bank, which must either } \\
\text { liquidate the assets and distribute the proceeds to investors, or, with BaFin's approval, } \\
\text { transfer management of the fund to another CIS operator. If a fund is dissolved, the } \\
\text { operator must prepare a dissolution report equivalent to an annual report, and subject to } \\
\text { external audit. }\end{array}$ \\
\hline Assessment & Fully implemented \\
\hline \multicolumn{2}{|l|}{ Comments } \\
\hline Principle 19. & $\begin{array}{l}\text { Regulation should require disclosure, as set forth under the principles for issuers, which is } \\
\text { necessary to evaluate the suitability of a collective investment scheme for a particular } \\
\text { investor and the value of the investor's interest in the scheme. }\end{array}$ \\
\hline Description & $\begin{array}{l}\text { Prospectuses } \\
\text { Section } 42 \text { of InvG provides a detailed set of requirement for fund prospectuses. It } \\
\text { requires that a prospectus for the offer of funds to retail investors to be published and } \\
\text { filed with BaFin "without undue delay" after it is first used. BaFin does not approve fund } \\
\text { prospectuses but the BaFin team responsible for the relevant CIS operator reviews it } \\
\text { and, if is defective, BaFin can order termination of the marketing of the CIS and take } \\
\text { action for an administrative offence. }\end{array}$ \\
\hline
\end{tabular}


As well as a full prospectus, a simplified prospectus must be published. ${ }^{19}$ The simplified prospectus requirement does not apply to real estate funds, infrastructure funds and hedge funds.

Both the full prospectus and the simplified prospectus must contain all information material to making an informed judgment, and a clear and easily comprehensible explanation of the risk profile of the fund. The full prospectus must contain detailed information specified in the legislation, including a profile of a typical investor in the fund. Certain types of funds (real estate funds, infrastructure funds, hedge funds) are subject to additional disclosure requirements.

Information of material importance that becomes out of date must be updated in both the full and the simplified prospectus-see Section 42(5) of InvG.

Some information-such as fees and charges-must be set out in the fund's rules. Funds rules must be attached to the full prospectus and also must be made available free of charge on request.

If a prospectus is defective, BaFin can order termination of marketing and take action for administrative offence: section 143(2) InvG.

Advertising

Advertising material must refer to the prospectus and how it can obtained. Advertising relating to some types of funds (such as funds of hedge funds) must contain specified disclosures. BaFin can prohibit some types of advertising, such as that containing misleading material.

The legislation prohibits public marketing of hedge funds (Section 112(2) Investment Act) and funds not permitted to be offered in Germany (Part 4 of InvG).

Reports

For each CIS fund it manages, a CIS operator must prepare an annual report and publish it no later than 4 months after year end. The annual report must include a report on the CIS's activities and any significant information that will enable investors to assess its performance. Half yearly reports are also required. Both reports must be published in the Federal Gazette.

Annual reports and half yearly reports contain financial information and other information about fund activity. These must be made available to holders of interests free of charge (sections 44-45 of InvG (German funds) and section 121(1) (foreign funds)).

\section{Accounting standards}

Accounting standards used in the preparation of CIS reports are set out in InvRBV. The standards are designed in accordance with the international accounting principle of fair valuation.

\footnotetext{
${ }^{19}$ The simplified prospectus is to be replaced by a 2 page Key Investor Document by July 2011 in the German legislation implementing Directive 2009/65/EC.
} 


\begin{tabular}{|c|c|}
\hline Assessment & Fully implemented \\
\hline Comments & \\
\hline Principle 20. & $\begin{array}{l}\text { Regulation should ensure that there is a proper and disclosed basis for asset valuation } \\
\text { and the pricing and the redemption of units in a collective investment scheme. }\end{array}$ \\
\hline Description & 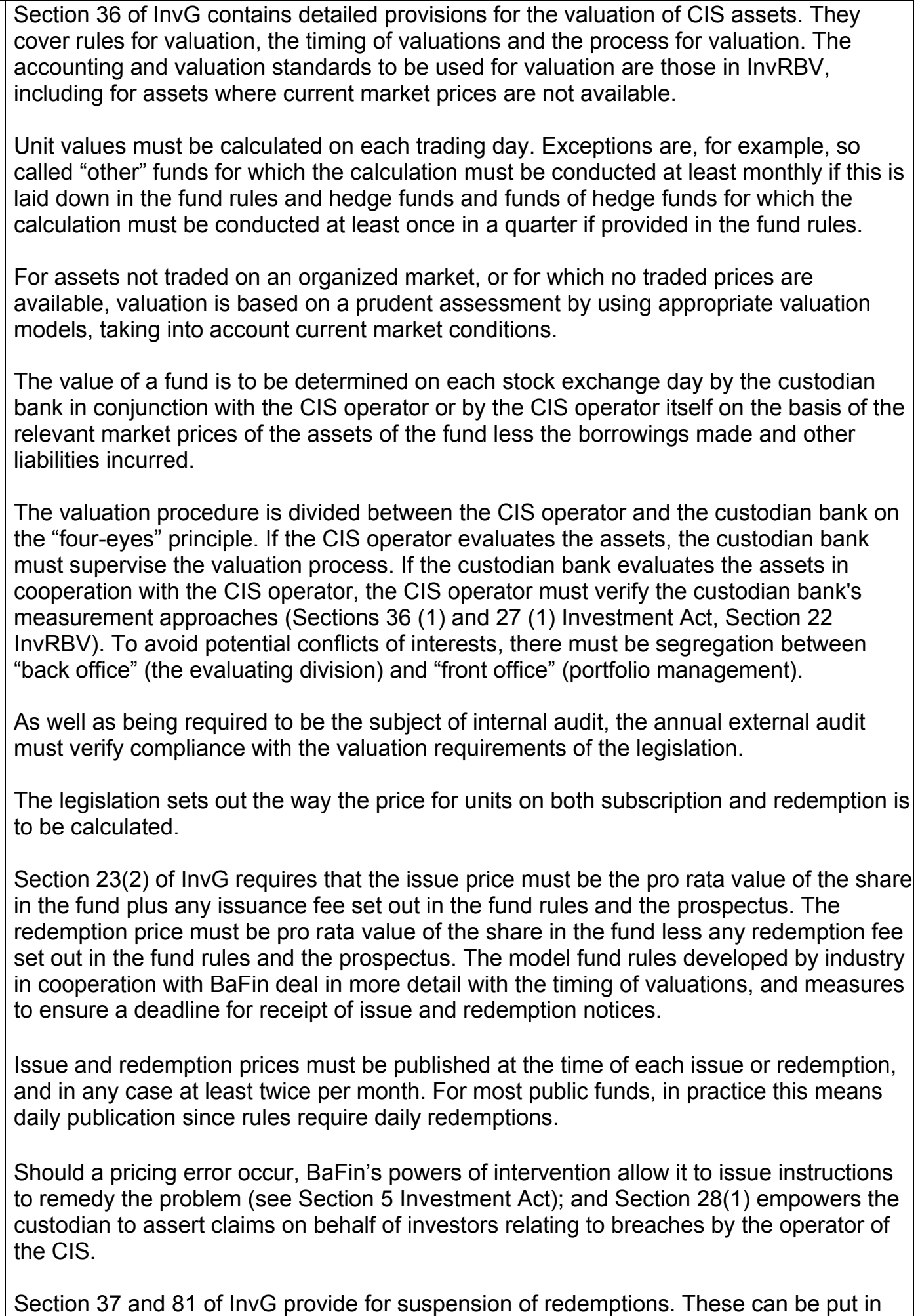 \\
\hline
\end{tabular}




\begin{tabular}{|c|c|}
\hline & 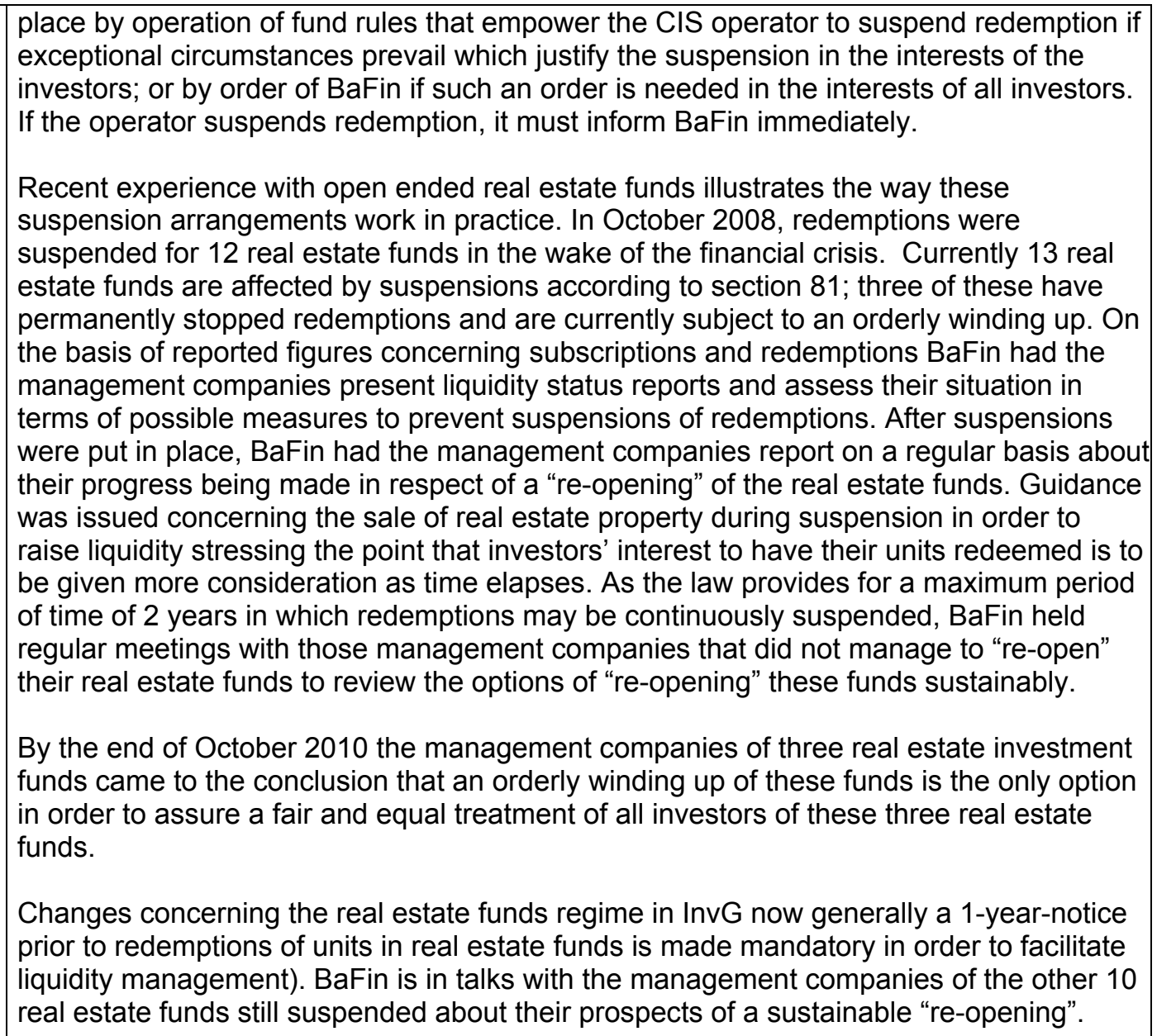 \\
\hline Assessment & Fully implemented \\
\hline \multicolumn{2}{|l|}{ Comments } \\
\hline \multicolumn{2}{|r|}{ Principles for Market Intermediaries } \\
\hline Principle 21. & Regulation should provide for minimum entry standards for market intermediaries. \\
\hline Description & $\begin{array}{l}\text { Legislative and industry background } \\
\text { The main legislation governing the authorization and ongoing regulation of market } \\
\text { intermediaries is KWG (Gesetz über das Kreditwesen, KWG). BaFin is responsible for } \\
\text { administering this legislation as well as other legislation relating to entities licensed } \\
\text { financial services providers under KWG, notably the Securities Trading Act (WpHG). } \\
\text { Section } 32 \text { of KWG requires a person to hold a license to carry on a business of } \\
\text { providing financial services. The KWG definition of financial services (section 1(1a)) is in } \\
\text { broad terms and covers a wide range of activities. The definition covers most forms of } \\
\text { financial market activity involving financial instruments, including proprietary trading and } \\
\text { providing customer-specific advice. A person conducting a multilateral trading facility is } \\
\text { also a financial services institution for the purposes of KWG licensing requirements. } \\
\\
\text { Financial instruments are likewise defined in broad terms to include of equity and debt } \\
\text { securities, options over these securities, units in collective investment schemes, money } \\
\text { market instruments and derivatives. Derivatives are defined to include both exchange- } \\
\text { traded instruments (such as futures and options) and OTC instruments. See section } \\
\text { 1(11) of KWG. As noted under Principle 1, some types of financial instruments-such as }\end{array}$ \\
\hline
\end{tabular}


closed end funds-are not financial instruments for the purposes of KWG licensing regime, and are subject to lesser regulation.

The main categories of licenses issued by BaFin are:

a. investment broking (buying and selling, or arranging to buy and sell financial instruments)

b investment advice

c. contract broking (buying and selling financial instruments in the name of and on account of third parties)

d. portfolio management (discretionary trading on behalf of individual clients)

e. asset management.

Licensed banks dominate the market intermediary business, with over 1,800 banks authorized to carry on financial services. Some 770 nonbank entities are licensed to provide financial services. This industry structure means that the majority of industry participants are regulated as banks and aspects of the regulation that applies to them flows from their status as credit institutions (banks). For example, only an institution licensed as a bank may hold assets or funds on behalf of investment services clients. This means that, as a general rule, capital rules in practice apply quite differently to nonbank licensees.

\section{Authorization}

All applicants for authorization must supply detailed information. This includes information about:

a. the identity of managers and direct and any shareholder with more than 10 percent of the capital or voting rights of the applicant (a qualified participating interest)

b. the applicant's business plan

c. available resources, including initial capital

d. ethical standards of managers and qualified participating interest holders

e. the competence of managers

f. internal controls, risk management and supervisory systems

(See section 32 KWG.)

\section{Authority of Regulator}

BaFin must refuse a license if minimum capital requirements are not met or it has adverse evidence about the integrity or competence of managers or the integrity of holders of qualified participating interests. It has the discretion to refuse a license if it is aware of facts that warrant the assumption that effective supervision will be impaired. See Section 33 KWG.

BaFin also has the power to revoke an authorization, including if it becomes aware of information that would justify refusal of authorization. As a matter of general administrative law, an authority such as BaFin has the power to revoke an administrative act it has taken, and this includes the grant of an authorization. See Section 35 KWG and Sections 48 and 49 of the Act on Administrative Enforcement (VwVfG).

BaFin has broad powers to support its regulation of authorized institutions, including the power to instruct licensee to cease or limit activities; to demand the dismissal of managers; and to transfer the powers of institution's board to a special commissioner. 


\begin{abstract}
See Section 36 and Section 46 KWG.
BaFin also has the broad information gathering and enforcement powers described under Principles 8 and 9.
\end{abstract}

\title{
Ongoing requirements
}

All authorized institutions must report to BaFin (and the BundesBank) any material changes in personnel, financial position, legal form or organizational structure; and changes in or acquisition of qualified participating interests (significant shareholdings). See Section $24 \mathrm{KWG}$ and the related Ordinance on Reports according to Section 2c KWG and Section 104 VAG, Inhaberkontrollverordnung, InhKontrollV).

\section{Public disclosure of licensed intermediaries}

The legislation requires BaFin to publish details of the grant or withdrawal of licence, including activities permitted under the license. BaFin makes these details available through its website. [Relevant legislative provision: s32(4) KWG]. Details on the legal form of the institution, names of managers and members of supervisory board and individuals authorized to act in the licensee's name are on the Commercial Register rather than BaFin's website.

\section{Supervision and enforcement powers}

As noted under Principles 8 and 9, BaFin has extensive powers to monitor compliance by market intermediaries with their obligations under the regulatory regime. As a general rule, BaFin appears to be inclined to corrective action rather than administrative penalties in its dealings with regulated entities.

\section{Supervision practice}

The main techniques BaFin uses in the supervision of market intermediaries are outlined under Principle 10.

Strong reliance is placed on the work of auditors, especially on the annual compliance audits carried out by the regulated entity's auditor. BaFin staff may decide to participate in the yearly audits performed by external auditors; and BaFin can determine key issues for these external audits within the scope of the audits.

Additionally, BaFin staffs meet with board members, compliance officers or other staff of intermediaries when there are compliance issues, such as indications of a breach of regulation or significant customer complaints or a change of the scope of the business.

For all intermediaries, the allocation of supervisory resources, also for the contacts with the supervised entities, is based on a risk assessment.

BaFin also holds quarterly meetings with the banking and investment firms' associations to discuss current issues. In these meetings, common violations across investment firms will be discussed as well as all other questions on the applicable code of conduct regulations, matters of current interest (e.g., due to press coverage), or new legislative proposals. Representatives of the associations of all the supervised investment firms 


\begin{tabular}{|c|c|}
\hline & 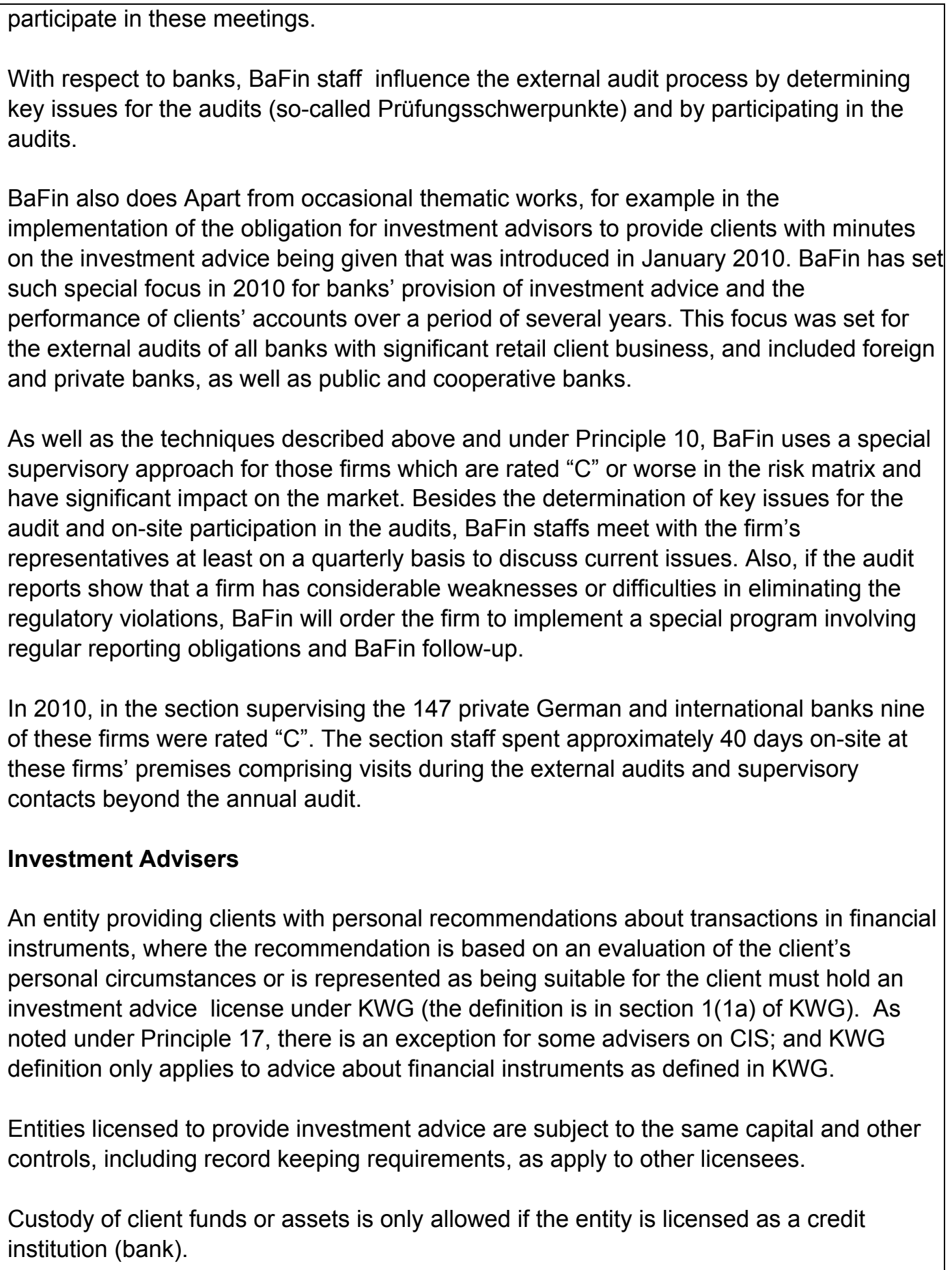 \\
\hline Assessment & Broadly implemented \\
\hline Comments & $\begin{array}{l}\text { In its monitoring of compliance by market intermediaries, BaFin is heavily reliant on } \\
\text { analysis of audit reports. On-site inspections are used, especially for entities with higher } \\
\text { risk ratings, and some thematic work is done. But both techniques are relatively sparingly } \\
\text { used and continuing reliance is placed on annual compliance audits, including for } \\
\text { adjustments to risk ratings. } \\
\text { The comments made under Principle } 10 \text { apply in the assessment of Principle } 21 \text {, which }\end{array}$ \\
\hline
\end{tabular}




\begin{tabular}{|c|c|}
\hline & $\begin{array}{l}\text { contemplates the use of on-site inspections of regulated entities regulated as a routine } \\
\text { part of the regulator's activities. } \\
\text { As noted under Principle 10, a benefit of the audit system is that all regulated entities are } \\
\text { reviewed annually. Nonetheless, on balance the assessor considers that the regulatory } \\
\text { measures adopted for the supervision of market intermediaries do not place sufficient } \\
\text { emphasis on the use of on-site inspections, both where potential problems occur at } \\
\text { individual firms and more broadly for thematic reviews of specific compliance issues. As } \\
\text { a result, BaFin has a less than optimal presence in the marketplace, and risks its overall } \\
\text { supervisory activity being too reliant on backward looking indicators. In particular, they } \\
\text { may mean that BaFin is not in a position to detect at an early stage patterns of market } \\
\text { conduct that have a potential adverse impact on regulated entities obligations, especially } \\
\text { conduct obligations relating directly to investor protection issues. } \\
\text { It is recommended that BaFin review its approach to the supervision of CIS activity by: } \\
\text { a. continuing to refine its approach to assessing and scoring risk; and } \\
\text { b. making more frequent use of on-site inspections to monitor compliance, both on a } \\
\text { risk score basis and for thematic issues such the selling practices of market } \\
\text { intermediaries. }\end{array}$ \\
\hline Principle 22. & $\begin{array}{l}\text { There should be initial and ongoing capital and other prudential requirements for market } \\
\text { intermediaries that reflect the risks that the intermediaries undertake. }\end{array}$ \\
\hline Description & $\begin{array}{l}\text { KWG and the Solvency Ordinance (Solvabilitätsverordnung, SolvV) govern the capital } \\
\text { requirements of financial services institution licensed under the Banking Act. These } \\
\text { provisions are based on and incorporate the standards of the EU Capital Requirements } \\
\text { Directives } 2006 / 48 / E C \text { and } 2006 / 49 / E C \text { (Capital Requirements Directive, CRD). } \\
\text { Minimum capital requirement } \\
\text { Entities licensed as financial services institutions are subject to initial capital } \\
\text { requirements under s33 of KWG. } \\
\text { a. entities that do not hold client funds/assets and do not deal on their own account: } \\
€ 50,000 \\
\text { b. entities that may hold client fund/assets but do not deal on their own account: } \\
€ 125,000 \\
\text { c. entities that deal own account dealings (and securities trading banks): €730,000 } \\
\text { In some cases, indemnity insurance is accepted as a substitute for these minimum } \\
\text { capital requirements. } \\
\text { Ongoing capital requirements } \\
\text { Entities are also subject to ongoing capital requirements set out in KWG (Section } 10 \text { ), } \\
\text { which sets out what is to be recognized as capital for regulatory purposes, and the } \\
\text { SolvV, which specifies the minimum amount of capital to be held. } \\
\text { For ongoing capital purposes, licensed entities fall into two groups (see Section } 2 \text { of the } \\
\text { SolvV): } \\
\text { a. financial services institutions that (i) do not conduct a proprietary trading business and }\end{array}$ \\
\hline
\end{tabular}


(ii) do not as investment brokers, contract brokers or portfolio managers hold customer funds or assets or deal in financial instruments on their own account. These entities must maintain initial capital and must also meet the liquidity test in section 11 of KWG (institutions must investment funds so as to ensure adequate liquidity for payment purposes at all times).

b. other financial services institutions, including credit institutions (banks) and securities firms not within the exceptions in (a). These institutions must comply with the full capital requirements in KWG and the Solvency Regulation.

Under these requirements, institutions must quantify credit/counterparty risk, operational risk and market risk and must support them with own funds. Institutions are required to hold at least an overall capital ratio of 8 percent against risk weighted assets. These provisions apply to the consolidated and individual entity levels.

The eligible components of an institution's or a group's own funds (including positions to be deducted) are listed in Section 10 (2) to (2c) of KWG which reflects the European Capital Requirements Directive (CRD).

The individual risk profile of the institution is considered in the calculation of capital requirements, either through the credit risk standardized approach or the internal ratings based approach. Operational risks and market price risks are taken into account when calculating the capital ratio. The calculations take into account credit risk (including balance sheet, derivatives and off-balance sheet exposures (sections 11-14 of the Solvency Ordinance)); market risk exposures (Section 295), commodities positions (Section 296) and interest rate and equity price related risks (Section 298).

Unlicensed affiliates or off balance sheet activities are regulated though rules for consolidated supervision or though minimum capital requirements under Sections 10 , $10 \mathrm{a}$ and $10 \mathrm{~b}$ of KWG.

\section{Guarantee scheme}

Financial services institutions licensed to provide financial services such as investment broking, contract broking, financial portfolio management and trading for own account under KWG are required to secure deposits and liabilities from investment business through membership of an investor compensation scheme in accordance with the Deposit Guarantee and Investor Compensation Act (Einlagensicherungs- und Anlegerentschädigungsgesetz, EAEG). If compensation is payable, the creditor of an institution has a right to compensation as provided in the EAEG from the compensation scheme to which the institution belongs (Section 3 EAEG).

For the securities market, non-bank licensees belong to a statutory Investor Compensation Fund established by EAEG. Licensees who are banks may belong to one of the non-statutory compensation schemes established the banking industry, such as the Deposit Protection Fund of German Banks.

Compensation is payable if BaFin determines that, for reasons directly related to its financial circumstances, an institution is unable to repay deposits or meet its liabilities arising from investment business and there is no prospect of repayment or the liabilities being met at a later date (section 1(5) EAEG). The claim to compensation of the creditor 
of the institution is based on the amount of a creditor's deposits or liabilities resulting from investment business, taking into account any set-off and counterclaims. There is no claim to compensation if deposits or funds are not denominated in the currency of a state of the EEA or in Euros. The amount of the claim to compensation is limited to 90 percent of deposits to a maximum EUR 20,000, and 90 percent of other liabilities arising from investment business to a maximum of EUR 20,000 (section 4 EAEG).

A licensed financial services institution must inform non-institutional investors about its membership in an investor deposit guarantee scheme (see Section 23a KWG).

If claims by clients exceed resources of the statutory Investor Compensation Fund, the Fund can demand additional contributions from its member firms. The Fund can also raise loans if required. The Fund itself decides about possible pro rata compensation and the order of disbursement.

The funding base of the Statutory Fund has come under pressure in recent years as a result of a large number of retail investor claims resulting from the failure of a single licensed institution to meet its obligations to customers.

\section{Reporting and monitoring}

Compliance with the minimum and ongoing capital requirements is monitored through the institutions' monthly financial reports (Section 25(1) KWG) and quarterly reports on capital adequacy (Section 6 Solvency Ordinance). These reports are submitted to the Deutsche Bundesbank, which analyses them and passes on the reports and its analysis to BaFin.

Financial statements audited by an independent auditor must be submitted to BaFIn and the Deutsche Bundesbank within 3 months after end of financial year (Section 26 KWG).

Financial services institutions must comply with financial requirements at all times. Under Section 7(1) of the Solvency Ordinance, BaFin and the Deutsche Bundesbank must be immediately notified if a licensee:

a. falls below the minimum capital requirements; or

b. sustains a loss of 25 percent of the institution's liable capital;

BaFin is authorized by Sections 45 and 46 KWG to take formal measures, including by:

a. prohibiting withdrawals by proprietors or shareholders and distribution of profits;

b. by prohibiting or limiting lending; and

c. requiring specific risk-reducing measures, if the institution fails to restore the minimum capital ratio within an appropriate period;.

If there is a threat to an institution's ability to meet obligations to creditors, BaFin can also issue instructions to the institution's management, to prohibit deposit-taking or lending, to prohibit proprietors or managers from carrying out their activities or to appoint a supervising person. Since 2009, if the institution's financial or revenue situation indicates that the institution will not be able to meet its capital requirements in a sustainable way, BaFin can take these measures before an actual breach of the minimum capital requirements occurs. 


\begin{tabular}{|c|c|}
\hline Assessment & Fully implemented \\
\hline \multicolumn{2}{|l|}{ Comments } \\
\hline Principle 23. & $\begin{array}{l}\text { Market intermediaries should be required to comply with standards for internal } \\
\text { organization and operational conduct that aim to protect the interests of clients, ensure } \\
\text { proper management of risk, and under which management of the intermediary accepts } \\
\text { primary responsibility for these matters. }\end{array}$ \\
\hline Description & 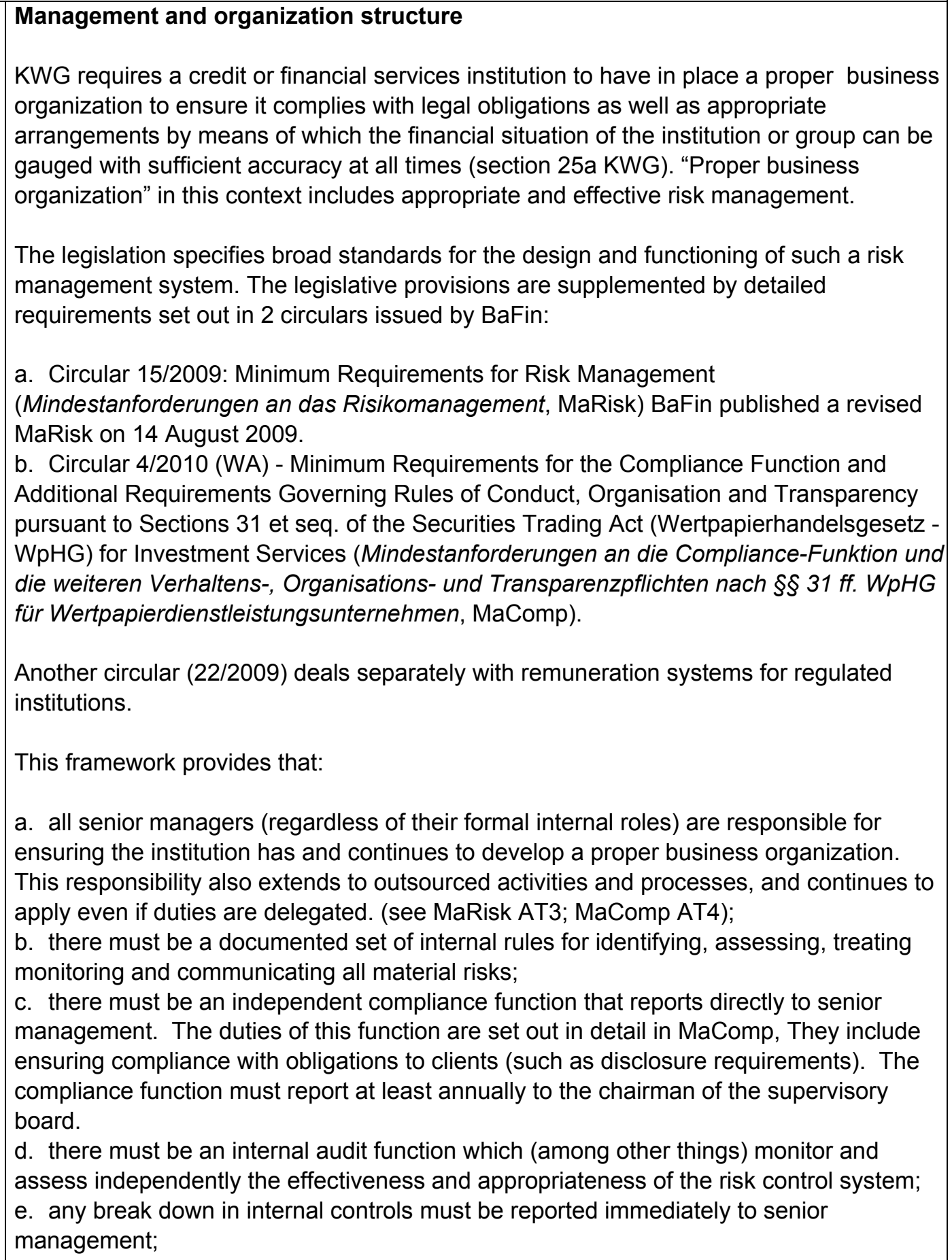 \\
\hline
\end{tabular}


A regulated institution must implement effective and transparent processes to ensure adequate and timely processing of complaints from retail clients and to record each complaint as well as the measures taken to remedy the complaint (section 33 (1) no. 4 WpHG).

\section{Client funds and assets}

The basic principle for client assets is that only institutions licensed as credit institutions are permitted to hold client funds and assets. Safe custody and administration of securities for the account of others is treated under s1(1) of KWG as component of banking business and thus may be performed only by entities licensed as credit institutions.

Section $34 a(1)$ of the Securities Trading Act requires financial services institutions that receive client funds in connection with an investment service they provide to keep them separately from any other funds or assets (whether their own or other clients') and to deposit them without delay in a trustee account with an institution licensed to conduct a deposit-taking business (or a comparable institution in the EEA or a third party jurisdiction).

Section $34 a(2)$ applies analogous rules to client securities (as defined in the Act).

\section{Client funds}

Client funds and assets must be identified as such to the custodian bank. The Safe Custody Act (Depotgesetz, DepotG) contains provisions to protect investors who entrust tradable securities to a credit institute for safekeeping. To protect investors and their securities, DepotG provides for different forms of safekeeping (collective deposit and individual safekeeping). In addition to the right to separation. DepotG provides for further mechanisms to protect investors against the risks of third party safekeeping such as restricting claims of rights to pledge or retention (section 4).

For investment firms that are deposit-taking banks, client money will in most cases be in the form of deposits. These are not required to be held separately from the proprietary assets of the institution. However, such deposits must be covered by a deposit guarantee scheme, and are also protected by the more stringent regulation applying to banking business.

\section{Client assets}

A deposit business as defined in section 1(1) sentence 2 no. $5 \mathrm{KWG}$ can be provided in different forms. Generally, the securities are entrusted to a bank for central depository of securities (collective deposit) unless the depositor requires individual safekeeping.

For collective deposits, the depositary may keep safe securities unsegregated from its own assets of the same kind or those of third parties or entrust those to a third party for collective depositing only when the depositor has given express and written consent (see Section 5 (1) sentence 2 DepotG). The depositary may entrust the securities to a third party, in most cases a bank for central depository of securities. In case of individual safekeeping, the depositary must keep safe securities separately from other assets and under an externally recognizable designation of the depositor (Section 2 DepotG). 
Under DepotG, investment firms are not allowed to hold omnibus accounts and securities of one client cannot be affected by activities of other clients.

Reporting to clients

A depositary is required to issue a securities account statement. Under a regime set out in the Depot-Bek ${ }^{20}$ ( no. $11(2)$ ), a securities account statement given to a client s must include information about:

a. securities entrusted to the credit institute individually with their nominal amount or number;

b. the exact name of the security type including the information about the characteristics and form of safekeeping.

Clients must be able to understand how they own their securities. These requirements also apply to contractual claims (e.g., purchase and delivery of securities).

There are no legal requirements for clearing houses or other central counterparties to maintain the separate identification of collateral posted by an investment firm for its client positions. Eurex Clearing AG requires clearing members to transfer proprietary funds for both client and proprietary positions. Under its clearing conditions clearing members have to ask clients to transfer collateral equivalent to the one transferred by the clearing member to Eurex, but no segregation of assets is required at the clearing member level. Any margin segregation requirements at that level are determined by the laws applicable to the relevant clearing member and its arrangements with its clients.

\section{Client information, know your client and suitability rules}

When providing investment advice or portfolio management, a licensee must obtain all necessary information about the customer's knowledge and experience in the investment field relevant to the specific type of product or service, his financial situation and his investment objectives so as to enable the intermediary to recommend to the customer the investment services and financial instruments that are suitable for him. Where the intermediary does not obtain the information required, the licensee must not recommend investment services or financial instruments to the customer (Section 31 (4) WpHG)

When providing investment services other than advice and portfolio management, the licensee must ask the customer to provide information about his knowledge and experience in the investment field relevant to the specific type of product or service offered or requested to enable the intermediary to assess whether the investment service or product envisaged is appropriate for the client. If the intermediary comes to the conclusion that the product or service is not appropriate to the customer, the intermediary must warn the customer. If the customer chooses not to provide the information required or provides insufficient information, the intermediary must warn the customer that it is not able to determine whether the service or product envisaged is appropriate for the

\footnotetext{
${ }^{20}$ Official Requirements regarding Safe Custody Business, Depot-Bek (Amtliche Anforderungen an das Depotgeschaft - Bekanntmachung über die Anforderungen an die Ordnungsmäßigkeit des Depotgeschäfts und der Erfüllung von Wertpapierlieferungsverpflichtungen).
} 
customer (Section 31 (5) WpHG).

\section{Customer access to terms and conditions of services}

Intermediaries that provide an investment service other than investment advice are required to enter into a written basic agreement with the customer setting out the essential rights and obligations of the firm and the customer (Section 34 (2) sentence 2 WpHG). The intermediary must provide this agreement to the customer in paper or another durable medium. The intermediary must inform the customer about the terms of the agreement before the customer is bound by it (Section 5 (2) and (3) sentence1 of the Ordinance on the Conduct and Organization of Investment Services Enterprises, Wertpapierdienstleistungs-Verhaltens- und Organisationsverordnung, WpDVerOV). If this is not possible, because the agreement was concluded by telephone at the request of the client, the information must be provided immediately after the client is bound by the agreement (Section 5 (3) sentence 2 WpDVerOV).

In addition, licensees providing investment advice are required by Section 34(2a) of the Securities Trading Act to take minutes of any investment advice session, which must be signed by the advice giver and must be provided to the client before any transaction resulting from the advice is concluded. Where this is not possible (for example telephone discussions), the licensee may accept a client order if requested to do so by the client, but only if it permits the client to withdraw from the transaction after reviewing the investment advice.

\section{Statement of account and information on remuneration}

The Ordinance on the Conduct and Organization of Investment Services Enterprises (Wertpapierdienstleistungs-Verhaltens- und Organisationsverordnung, WpDVerOV) sets out detailed requirements for reports to clients of financial services institutions.

Reports required by Sections 8 and 9 of the WpDVerOV include:

a. transaction confirmations

b. periodic reports for clients of portfolio management services, 6 monthly or 3 monthly if requested by the client. Clients can also request elect to receive information about executed transactions on a transaction-by-transaction basis, in which case the intermediary must provide promptly to the client, on the execution of a transaction by the portfolio manager, the essential information concerning that transaction in a durable medium

c. periodic reports for holder of interest in collective investment undertakings in relation to transactions executed periodically, at least 6 monthly

Section 5(2) of the WpDVerOV requires a licensee to inform their retail clients and potential retail clients with information about costs and associated charges including where relevant:

a. the total price to be paid by the client in connection with the financial instrument or the investment service or ancillary service, including all related fees, commissions, charges and expenses, and all taxes payable via the investment firm or, if an exact price cannot be indicated, the basis for the calculation of the total price so that the client can verify it. Commissions charged by the licensee must be separately 
itemized;

b. where any part of the total price is to be paid in or represents an amount of foreign currency, an indication of the currency involved and the applicable currency conversion rates and costs;

c. notice of the possibility that other costs, including taxes, related to transactions in connection with the financial instrument or the investment service may arise for the client that are not paid via the investment firm or imposed by it;

d. the arrangements for payment or other performance.

\section{Books and records}

Section 34 of the Securities Trading Act requires financial services institutions to keep records of the investment services they provide, and records of transactions undertaken by them, to enable BaFin to monitor their compliance with their obligations. Records must be kept for at least 5 years. These requirements are in addition to licensees' record keeping obligations under general commercial law, and under the record keeping requirements under the MiFID regime (EC 1287/2006).

\section{Appropriate systems of customer protection, risk management and internal and operational controls}

A licensed financial services institution must ensure that all clients are treated in a fair, honest and professional manner (Section 33(1) no. 3 and Section 31(1) WpHG). It must also establish a conflicts of interest policy (section 13 (2) WpDVerOV) and a best execution policy (Section 33a (1) WpHG).

The Securities Trading Act contains detailed provisions on the execution of customer orders in Sections 31c (handling client orders) and 33a (best execution). These sections provide for the way in which client orders are to be recorded; the sequence of execution; the circumstances and conditions under which aggregation of orders is permitted (including client and licensee orders); how allocation is to occur; and communication with clients about orders. They also prohibit misuse by the licensee of information about client orders.

\section{Handling conflict of interests}

Section 31(1) of the Securities Trading Act requires financial services institutions to avoid conflicts of interest wherever possible and to ensure that in the event of unavoidable conflicts of interest customers' orders are executed with due regard to customers' interests. The general nature and/or sources of conflicts of interest must be disclosed if they cannot be avoided. The intermediary is required to identify the types of conflict of interest that arise in the course of providing investment services and whose existence may damage the interests of a client.'

Under section 33 (1) no. 3 of the Securities Trading Act a financial services institution must maintain permanent and effective arrangements to allow it to take all reasonable steps to identify conflicts of interest between itself (including its employees and related parties) and its clients.

These general obligations are supplemented by specific provisions, such as the provision dealing with personal account dealings by employees of a financial services institution 


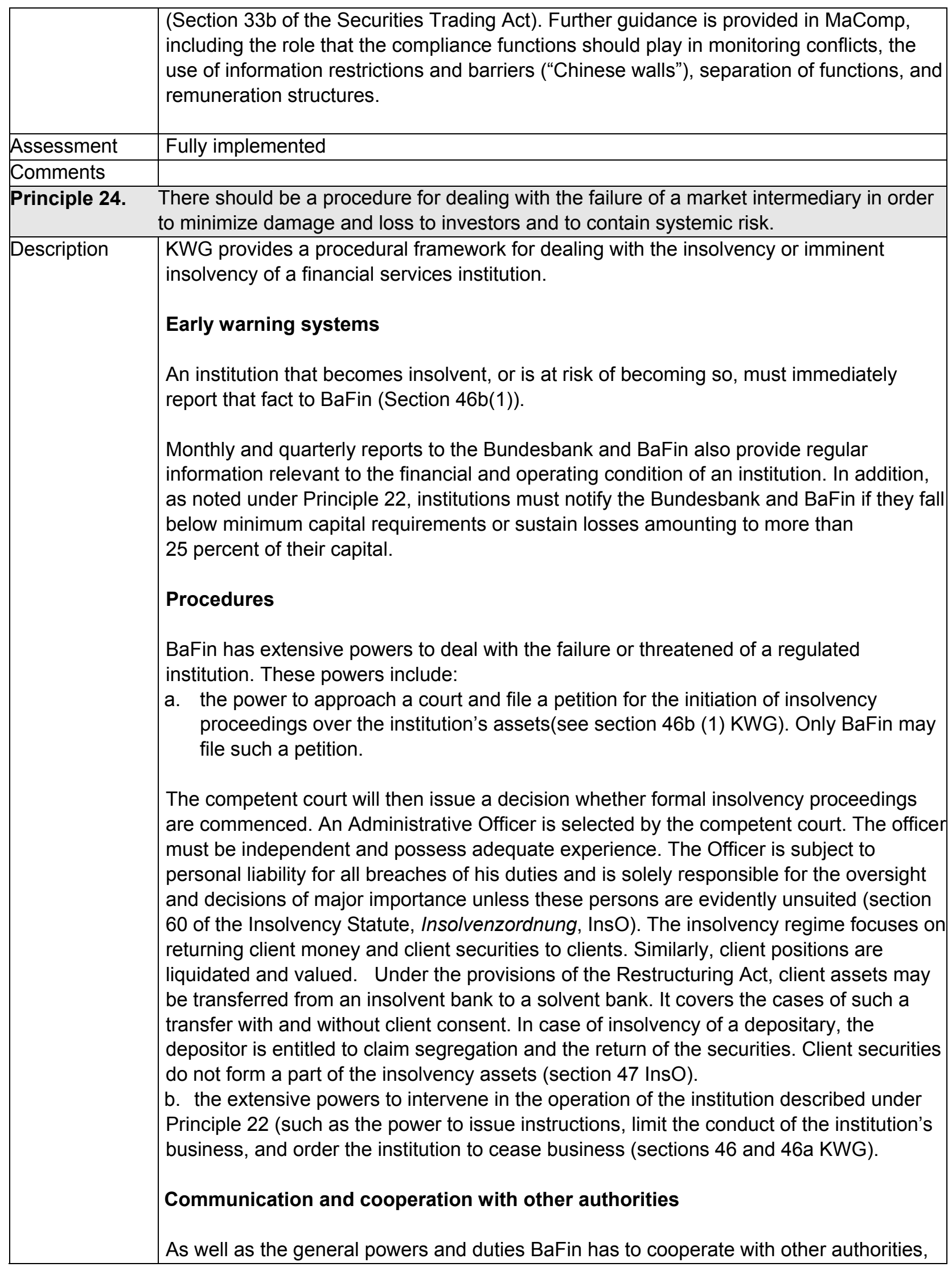




\begin{tabular}{|c|c|}
\hline & $\begin{array}{l}\text { both domestic and international (described under Principles } 11-13 \text { ), KWG contains } \\
\text { express provisions (sections } 46 \mathrm{~b}(2) \text { and } 46 \mathrm{~d} \text { ) requiring it to notify the relevant authorities } \\
\text { in EEA jurisdictions if it files a petition for insolvency for a domestic institution; and to } \\
\text { advise those authorities if BaFin forms the view that an institution domiciled in their } \\
\text { jurisdiction has insufficient liquidity (section } 53 \mathrm{~b}(4) \text {. }\end{array}$ \\
\hline & Fully implemented \\
\hline Comments & $\begin{array}{l}\text { BaFin relies heavily on regular reporting by intermediaries to make its early warning } \\
\text { system effective, and has adequate powers to deal with a firm facing insolvency. The } \\
\text { assessor accepts that there is a clear practical understanding of the steps that need to } \\
\text { be taken in such a case, and that BaFin can and would take those steps. Nonetheless, it } \\
\text { is desirable for there to be a clear and complete ex ante plan for dealing with the } \\
\text { threatened failure of both bank and non-bank firms. }\end{array}$ \\
\hline & $\begin{array}{l}\text { Principles for the Secondary Market } \\
\end{array}$ \\
\hline Principle 25. & $\begin{array}{l}\text { The establishment of trading systems including securities exchanges should be subject to } \\
\text { regulatory authorization and oversight. }\end{array}$ \\
\hline Description & $\begin{array}{l}\text { Organized market activity is subject to a comprehensive, if somewhat complicated, } \\
\text { legislative regime. } \\
\text { The Federal Exchange Act (Börsengesetz, BörsG) and regulations made under it (such } \\
\text { as regulations relating to admission to listing, }{ }^{21} \text { are supplemented by regulations made } \\
\text { by individual States, such as the regulations relating to exchanges in the State of Hesse, } \\
\text { or regulations dealing with individual exchanges such as Frankfurt and Eurex. }{ }^{22} \\
\text { Clearing and settlement facilities are regulated as banking activities under the Banking } \\
\text { Act. } \\
\text { Exchange markets } \\
\text { Under BörsG, exchanges are institutions established under German administrative law } \\
\text { having the legal status of a public authority acting with administrative powers. These } \\
\text { entities are separate from the entities that provide trading and clearing services to the } \\
\text { exchange market on a commercial basis (Administering and Operating entities). So for } \\
\text { example, the Frankfurt Stock Exchange is a public law body, with commercially oriented } \\
\text { trading and clearing services provided by a publicly listed company, the Deutsche Börse } \\
\text { group. Exchanges are subject to constitutional restrictions for public authorities, and } \\
\text { operate under the supervision of the relevant State-based Exchange Supervisory } \\
\text { Authority (ESA). } \\
\text { The Act requires an exchange to act through its executive bodies } \\
\text { a. Management Board (Geschäftsleitung), } \\
\text { b. Exchange Council (Börsenrat), } \\
\text { c. Trading Surveillance Office (Handelsüberwachungsstelle, TSO), and } \\
\text { d. Disciplinary Committee (Sanktionsausschuss). }\end{array}$ \\
\hline
\end{tabular}

${ }^{21}$ Verordnung über die Zulassung von Wertpapieren zum regulierten Markt einer Wertpapierbörse, BörsZulV.

${ }^{22}$ Such as Börsenverordnung des Landes Hessen, BörsV HE, and Börsenordnung für die Frankfurter

Wertpapierbörse, BO FWB 
All executive bodies act in a sovereign capacity. This includes the power to apply coercive measures under administrative law. Administrative decisions of an exchange's bodies can be appealed against in administrative courts.

The Exchange Council is the representative body of exchange users (trading participants, issuers and investors), and is elected by them every three years. The Exchange Council adopts the rules and regulations of the exchange and nominates and supervises the members of the management board. The management board is responsible for the conduct of the ongoing business of the exchange.

Each exchange is obliged to establish a Trading Surveillance Office (TSO). A TSOthough located at the exchange-is an independent body not subject to direction by the exchange. In particular:

a. the appointment and the dismissal of the Head of the TSO require the consent of the ESA;

b. the TSO is bound only by instructions issued by the relevant ESA;

c. as it acts in a sovereign capacity and orders given by the TSO are binding. They can be enforced using sovereign powers;

d. as an independent body, the TSO only reports to the responsible ESA.

Each TSO must keep and analyze complete records of all trading data of the relevant exchange. In practice, TSOs use databases and electronic monitoring systems designed to ensure to complete capture and comprehensive analysis of all exchange data. TSOs also have extensive rights of inspection. They are entitled to:

a. demand information, or documents from trading participants;

b. enter their premises during normal office hours;

c. require trading participants to disclose information regarding the ultimate beneficiaries, or obligors, of exchange trades.

TSOs must also inform BaFin regarding any indications of market manipulation or insider trading. TSOs are authorized to exchange data with other monitoring bodies in Germany or abroad, where this is necessary for the fulfillment of their duties, and provided that any exchange of data with foreign authorities is subject to confidentiality requirements which are comparable to German rules.

The Disciplinary Committee of an Exchange can take disciplinary action against trading participants for breaches of rules or provisions under exchange law, imposing fines of up to EUR 250,000 or suspending admission for up to 30 exchange trading days. The Disciplinary Committee can be convened by the ESA or by the management board of the exchange. At some exchanges, the Disciplinary Committee can act upon its own initiative. For example, in calendar 2009 the Disciplinary Committee of Frankfurt Stock Exchange imposed sanctions in 18 cases, with 7 cases pending. In practice, the largest fine imposed to date was EUR 208,000.

The ESAs of the Federal States (Länder) supervise exchanges and the trading participants. The ESA in each state usually forms part of the Ministry of Finance or the Ministry of Economics. Their regulatory authority includes:

a. the approval of exchange operations;

b. the approval or adoption of exchange rules and regulations; and

c. monitoring trading participants' and order book specialists' compliance with their 
duties (in particular, regarding orderly price determination and order execution).

ESAs also supervise the orderly settlement of exchange trades. They are authorized to take appropriate regulatory action in the event of any abuse. The ESA has to approve the appointment of members of the management board of the exchange.

ESAs have the same rights to access information and documents as TSOs. An ESA can also convene the Disciplinary Committee of the relevant exchange (Section 3 of BörsG).

BaFin is responsible for monitoring and enforcing compliance with market abuse prohibitions (insider trading, market manipulation), and listed entities' compliance with their disclosure obligations (including prospectus, continuous (ad hoc) disclosure and major shareholdings) and obligations under takeovers legislation. BaFin has sole responsibility for international information flows and cooperation with respect to regulated markets and market activity.

For exchanges, therefore, compliance monitoring functions are performed at three levels, exchange level (through the TSO); State level (by the relevant ESA); and BaFin.

\section{Authorization of exchanges}

Before they can operate, exchange markets require approval by the ESA of the relevant State (Land), pursuant to BörsG (Section 4 BorsG).

Currently 7 authorized exchanges operate securities markets (Frankfurt, München, Berlin, Hamburg, Hannover, Düsseldorf, Stuttgart), Eurex Deutschland based in Frankfurt operates an authorized derivatives exchange, and EEX operates an authorized energy exchange in Leipzig.

Under section 4 of BörsG, for an exchange to be granted a licence, BörsG provides that the relevant ESA must be satisfied (among other things) about:

a. the business case for the establishment of the exchange market

b. exchange resources

c. the integrity of senior managers and major shareholders

d. the ability of an applicant to comply with the regulation applying to exchanges.

BörsG mandates the key elements of an exchange's governance and structure (Exchange Council, Disciplinary Committee and TSO). See BörsG Section 7(1) (TSO); section 22 (Discplinary Committee; and Section 12 (Exchange Council).

Exchanges must also adopt rules - which are subject to approval by the relevant ESA that cover a large number of matters specified in the legislation and regulations made under that legislation. Matters covered in this way include:

a. admission to membership;

b. exchange organization;

c. types of trading;

d. exchange members' ability to meet obligations arising from their trading activities; and

e. the conditions under which the exchange's trading and settlement systems can be linked to external settlement systems. 


\begin{tabular}{|c|c|}
\hline & $\begin{array}{l}\text { ESAs can impose ongoing conditions on exchange operator and have extensive powers } \\
\text { of intervention to ensure orderly trading and settlement, and compliance with Exchange } \\
\text { Act and exchange rule obligations (section } 3 \text { BörsG). } \\
\text { Multilateral trading facilities } \\
\text { Conducting a market in the form of MTF is treated as a financial service requiring the } \\
\text { operator to be licensed as a financial services institution under the Banking Act Banking } \\
\text { Act (see Section 1(1a)). } \\
\text { As licensees MTFs are subject to the obligations common to all licensees. They are also } \\
\text { subject to additional special provisions under the Securities Trading Act (WpHG): } \\
\text { a. Under Sections } 31 \text { f, MTFS must have rules governing: } \\
\text { i. access by trading participants at least as stringent as those required for } \\
\quad \text { exchanges under BörsG; and } \\
\text { ii. the admission to trading and orderly trading in financial instruments; } \\
\text { They must also have control mechanisms for monitoring and recording all trading } \\
\text { activity; comply with Exchange Act provisions on price formation; and publish } \\
\text { information about the operation of the MTF; and } \\
\text { b. Under section } 31 \mathrm{~g}, \text { MTFs must comply with MiFld-standard requirements for pre- } \\
\text { and post-trade transparency. } \\
\text { BaFin has to date licensed } 2 \text { institutions to operate MTFs, Eurex Bonds and Eurex Repo. } \\
\text { Both these markets were well established before the requirement to register as MTFs } \\
\text { came into effect. Eurex Repo is a wholly owned subsidiary of the Eurex Frankfurt AG } \\
\text { (itself ultimately owned jointly by SIX Swiss Exchange AG and Deutsche Börse AG). } \\
\text { Eurex Bonds is owned } 79 \text { percent by Eurex Frankfurt AG, with the remaining } 21 \text { percent } \\
\text { held by major financial institutions. } \\
\text { BaFin monitors compliance by MTFs with their obligations as a licensed institution under } \\
\text { the Banking Act and the rules for MTFs set out in the Securities Trading Act (WpHG). } \\
\text { TSOs must report suspect insider trading and other market abuses to BaFin (section } 7(5) \\
\text { BörsG). } \\
\text { MTF operators are also required to report to BaFin serious contraventions of trading } \\
\text { rules and other threats to market integrity (Sections } 10 \text { and s31f( } 3 \text { ) WpHG). }\end{array}$ \\
\hline Assessment & Fully implemented \\
\hline \multicolumn{2}{|l|}{ Comments } \\
\hline Principle 26. & $\begin{array}{l}\text { There should be ongoing regulatory supervision of exchanges and trading systems, which } \\
\text { should aim to ensure that the integrity of trading is maintained through fair and equitable } \\
\text { rules that strike an appropriate balance between the demands of different market } \\
\text { participants. }\end{array}$ \\
\hline Description & $\begin{array}{l}\text { Exchange supervision } \\
\text { As described under Principle 25, ESAs have overall responsibility for supervision of } \\
\text { exchanges and monitoring and enforcing compliance with BörsG and related regulations. } \\
\text { They have extensive powers under Section } 3 \text { of BörsG to obtain information from market } \\
\text { operators and market participants and their clients and to intervene in market operations }\end{array}$ \\
\hline
\end{tabular}


(for example by suspending trading in one or more financial instruments).

ESAs monitor trading activities and the functions performed by the TSOs of the exchanges. The TSOs have access to all pre- and post-trade information and review trading and settlement data, operate electronic surveillance systems and conduct investigations to ensure compliance by participants with the regulatory framework, including exchange rules and regulations.

\section{Compliance monitoring}

\section{Exchanges}

[Note: The following information is based on information about the regulation of markets in the State of Hesse. The assessor did not have contact with ESAs in other States.]

BörsG makes TSOs responsible for front-line regulation of trading activity under the supervision of the relevant ESA (Section 7). ESAs run surveillance and compliance monitoring programs.

TSO's have continuous access to trading information. An ESA can demand information about trading activity from the exchange.

For exchange trading, monitoring of market activity takes place at three levels:

a. TSOs monitor trading and price formation;

b. ESAs examine misconduct and violations of stock exchange law; and

c. BaFin ensures that German securities and derivatives markets operate in accordance with the Securities Trading Act (WpHG).

If a TSO identifies irregularities, it informs the management board of the exchange and the ESA, which may then initiate proceedings against market participants before the Disciplinary Committee of the exchange. Among other measures, the Disciplinary Committee may impose fines and exclude the participants for up to 30 days from the exchange.

Apart from the Disciplinary Committee and the management board of the exchanges, the ESAs can impose sanctions on market participants. The main tasks of the ESA are the supervision of the integrity of the price formation process, investigations of violations of exchange regulations and development of preventive measures and supervision of proper trading of the exchange bodies. Their extended tasks encompass the supervision of the market participants admitted to exchange trading and contributions to legislation and exchange policy.

The ESAs are authorized to issue orders for the maintenance of order and for the conduct of business on the exchange (section 3 (5) BörsG). With regards to the exchange and the trading participants, they may issue any necessary orders which are designed to prevent violations of exchange law provisions and orders, or to eliminate irregularities which could impair the orderly conduct of exchange trading, the settlement of exchange transactions and the supervision thereof. For this purpose, they are empowered to order the suspension or discontinuation of exchange trading in one or more financial instruments, rights or economic assets.

Additionally, BaFin monitors compliance with the prohibitions and requirements of the 


\begin{tabular}{|c|c|}
\hline & $\begin{array}{l}\text { WpHG also as far as market manipulation and insider trading are concerned (section } 4 \\
\text { (2) WpHG). } \\
\text { In the State of Hesse, a total of ESA } 20 \text { staff are employed in the supervision of Frankfurt } \\
\text { Stock Exchange and Eurex; the ESA for the State of Hesse consists of } 8 \text { staff and its } \\
\text { routine functions include: } \\
\text { a. approval of new or changed rules for the markets; } \\
\text { b. case-driven matters, where non-compliance with the legislation or market rules is } \\
\text { examined. The ESA has daily contact with the TSO, and monitors for breaches of } \\
\text { exchange rules, and investigates and initiates disciplinary committee proceedings; } \\
\text { c. regular reviews of exchange activity. For example, the ESA has recently examined } \\
\text { at issues relating to the admission of trading participants, because of concern that } \\
\text { BörsG requirements were not being systematically complied with. } \\
\text { As part of their obligations as financial services institutions, MTFs are required to } \\
\text { maintain records of trading on their facilities. BaFin can require information to be } \\
\text { provided to it. } \\
\text { ESAs have the power to revoke an exchange authorization (see section s4(5) BörsG). } \\
\text { MTFs } \\
\text { BaFin does not appear to have developed an MTF specific compliance regime, and the } \\
\text { techniques it uses are those applying to licensed market intermediaries generally. It has } \\
\text { not yet carried out an on-site inspection of either of the two existing licensed MTFs. } \\
\text { BaFin can revoke the license of an MTF operator (section } 33 \text { KWG). }\end{array}$ \\
\hline Assessment & Fully implemented \\
\hline Comments & $\begin{array}{l}\text { The two existing MTFs licensed in the German market are well established, relatively } \\
\text { specialist, markets that pre-dated the MiFID compliant regime. In practice, they are } \\
\text { owned by the operator of licensed exchange markets, and operate within the overall } \\
\text { framework of the Deutsche Börse Group, but are not licensed as exchanges. The } \\
\text { combination of these factors means that the risk of non-compliance with the market } \\
\text { components of the regime that applies to them (such as the transparency rules) may be } \\
\text { small. But if other MTFs are established in Germany, this approach is unlikely to t be } \\
\text { adequate and would need to be supplemented by a more specifically designed } \\
\text { compliance regime. }\end{array}$ \\
\hline Principle 27. & Regulation should promote transparency of trading. \\
\hline Description & $\begin{array}{l}\text { Both exchange markets and MTFs are subject to pre- and post-trade transparency in line } \\
\text { with those applying to equities and equity options admitted to trading in an EEA market in } \\
\text { line with the MiFID directive. The MiFID requirements are imposed for exchanges by } \\
\text { sections } 30 \text { and } 31 \text { of BörsG (and for example, s173 BO FWB); and by for MTFs by } \\
\text { section } 31 \mathrm{~g} \text { of the Securities Trading Act (WpHG). } \\
\text { Pre-trade transparency } \\
\text { Pre-trade transparency requires disclosure of bid and offer prices, and volumes tradable } \\
\text { at those prices (section } 30 \text { BörsG). In practice, this rule is elaborated by exchange- }\end{array}$ \\
\hline
\end{tabular}




\begin{tabular}{|c|c|}
\hline & $\begin{array}{l}\text { specific regulations. For example, for Frankfurt Stock Exchange, section } 30 \text { BO FWB } \\
\text { provides that: } \\
\text { a. for floor traded market an estimated price must be published showing the range of bid } \\
\text { and ask limits at or between which the exchange price can be determined; } \\
\text { b. for continuous trading systems, at least the aggregate order volumes of the five best } \\
\text { price limits and order volumes for each price limit must be published; } \\
\text { c. for periodic auctions, either the indicative auction price or the best bid and/or offer } \\
\text { limit including the volume at that price must be published; and } \\
\text { d. for the pre-call and call of an auction in a continuous trading model where specialists } \\
\text { are used, the specialist's indicative quote must be published. } \\
\text { Waivers from these requirements are available, in accordance with the MiFID } \\
\text { requirements, for: } \\
\text { a. large scale orders that are large in scale as determined by MiFID; } \\
\text { b. some negotiated trades; } \\
\text { c. reference price systems, where the system executes trades at a price (or prices) } \\
\text { generated by another system and the price is considered reliable and is widely } \\
\text { published. } \\
\text { d. orders held in order management systems pending disclosure to the market (such as } \\
\text { iceberg orders). } \\
\text { For MTFs, the relevant provision is section } 31 \mathrm{~g} \text { of WpHG. } \\
\text { Fost-trade transparency } \\
\text { (MTFs) on reasonable commercial terms in an easily accessible form. } \\
\text { An ESA (for exchange markets) and BaFin (for MTFs) can allow deferred publication if } \\
\text { immediate publication is to the detriment of the trading parties (Section } 30 \text { BörsG; } \\
\text { Section } 31 \mathrm{~g}(4) \text { WpHG; and Articles } 18-20 \text { of the MiFID Implementing Regulation; Article } \\
28 \text { of MiFID Implementation Regulation). } \\
\text { transactions have to be published without delay. Under section } 174 \text { BO FWB, exchange } \\
\text { prices and the volume and time at which the trades were concluded must be published } \\
\text { immediately in real time and not later than three minutes after occurrence, subject to an } \\
\text { exception of delayed publication appears necessary to avoid disadvantage to the parties } \\
\text { to the transaction. } \\
\text { Fonsly }\end{array}$ \\
\hline Assessment & Broadly implemented \\
\hline Comments & $\begin{array}{l}\text { The transparency regime required by MiFID has been fully implemented for exchange } \\
\text { markets, MTFS and systematic internalizers, so there are the required levels of } \\
\text { transparency at each market venue. But in an environment where trading in equities can } \\
\text { take place on a range of venues, both within Germany and elsewhere, the absence of } \\
\text { standards for consolidation of post trade information detracts from the overall } \\
\text { transparency of the market for trading in shares. }\end{array}$ \\
\hline
\end{tabular}




\begin{tabular}{|c|c|}
\hline & $\begin{array}{l}\text { In the assessor's view, the transparency contemplated by Principle } 27 \text { is to be read in the } \\
\text { light of the current market environment shaped by developments in technology and the } \\
\text { competitive environment facilitated by MiFID. The current MiFID consultation identifies } \\
\text { concerns about the practical effectiveness of the current requirements for post-trade } \\
\text { transparency and raises issues about both comparability of post trade data and the } \\
\text { desirability of consolidating it to ensure full and effective transparency. The assessor } \\
\text { considers until these concerns are effectively resolved, the Principle should be rated } \\
\text { broadly implemented. }\end{array}$ \\
\hline Principle 28. & $\begin{array}{l}\text { Regulation should be designed to detect and deter manipulation and other unfair trading } \\
\text { practices. }\end{array}$ \\
\hline Description & 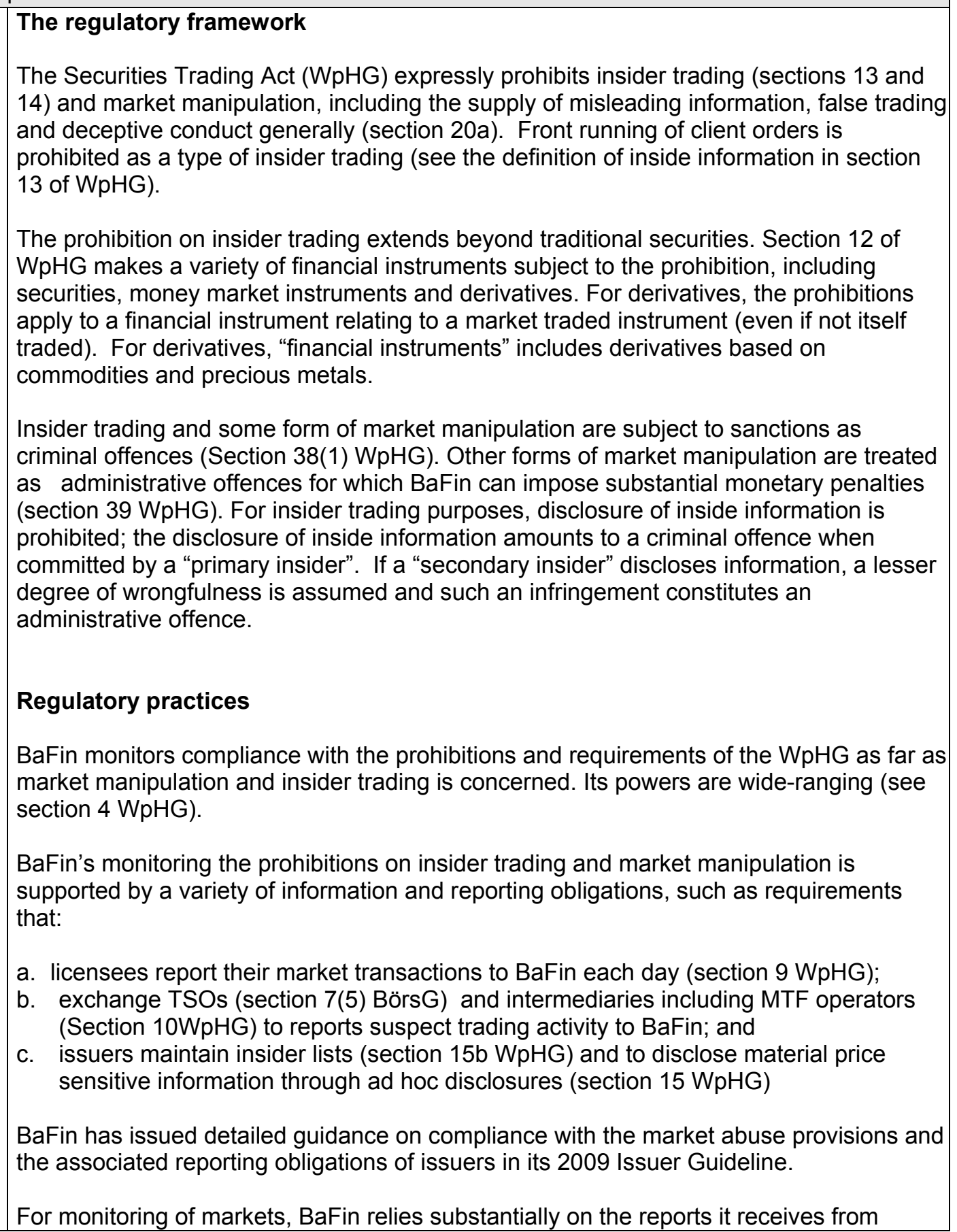 \\
\hline
\end{tabular}




\begin{tabular}{|c|c|}
\hline & $\begin{array}{l}\text { intermediaries, information from ESAs and TSOs, and its own monitoring of capital } \\
\text { market activity (such as takeovers and ad hoc disclosures). } \\
\text { Market participants report all completed transactions to the BaFin. These reports } \\
\text { constitute a database that aids investigation of suspicious trading and more general } \\
\text { analysis of market developments. } \\
\text { In 2009, there were ten court convictions in respect of insider trading one of which } \\
\text { resulted in custodial sentences for two offenders. In other cases, criminal fines were } \\
\text { imposed. In 2010, there were eleven court convictions for insider trading. } \\
\text { In the year 2010, BaFin focused particularly on market manipulation and commenced a } \\
\text { total of } 116 \text { new investigations. BaFin found evidence of criminal breaches of the } \\
\text { prohibition on market manipulation in } 62 \text { cases and reported } 109 \text { suspected persons to } \\
\text { the appropriate public prosecutor. } \\
\text { Cross market supervision } \\
\text { BaFin has access to cross market information through information flows from TSOs and } \\
\text { ESAs, and daily transaction reporting by market intermediaries of all trading (on-and off- } \\
\text { market), and through its ability to require documents and information from market } \\
\text { participants and others. TSOs can share information with one another. BaFin is the } \\
\text { competent authority for cooperation with authorities in other countries. It is party to the } \\
\text { CESR MMoU on the Exchange of Information and Surveillance of Securities Activities, } \\
\text { the IOSCO MMoU and a large number of bilateral MOUs. }\end{array}$ \\
\hline Assessment & Fully implemented \\
\hline Comments & \\
\hline Principle 29. & $\begin{array}{l}\text { Regulation should aim to ensure the proper management of large exposures, default risk } \\
\text { and market disruption. }\end{array}$ \\
\hline Description & $\begin{array}{l}\text { [Note: observations about compliance with this Principle are based on an examination of } \\
\text { the rules and procedures applying to the Frankfurt Stock Exchange and Eurex.] } \\
\text { Exchange participant are obliged by section <> of BörsG to In accordance with BörsG } \\
<>, \text { German exchanges have developed mechanisms to ensure the proper management } \\
\text { of large exposures and reduce the risk of default and resulting market disruption. The } \\
\text { main mechanisms are: } \\
\text { a. the use of central counterparty clearing; } \\
\text { b. requiring margins from market participants to support their ability to meet their } \\
\text { obligations arising from trading activities; } \\
\text { c. for Eurex, use of the power to impose position limits; } \\
\text { d. monitoring by TSOs and ESAs, using their powers to access information about the } \\
\text { trading activities of market participants and their clients. } \\
\text { Central counterparty clearing (CCP) } \\
\text { CCP is used for both Frankfurt Stock Exchange (Deutsche Börse) and Eurex, the two } \\
\text { largest exchanges in Germany. This means potential large exposures - at clearing } \\
\text { participants level - are monitored as part of the daily clearing and settlement process. } \\
\text { Margin requirements } \\
\text { Frankfurt Stock Exchange rules (Rules 19-24) require participants to provide margin for } \\
\text { the total risk from their exchange transactions. Eurex rules (Rule 4.8) require its }\end{array}$ \\
\hline
\end{tabular}


participants to provide margins for positions. Margins can be in the form of cash, securities, and bank guarantees.

The risk-based margining encompasses the entire process of measuring, calculating and administering the margin required for open positions in order to cover any contractual risks that may arise

Position limits

Eurex rules empower its board of management to set or alter position limits for trading participants to ensure orderly trading and avoid risk (Eurex Rules 4.7.1) and oblige the Eurex TSO to monitor compliance with such limits (4.7.3).

\section{Monitoring}

TSOs monitor adherence to the security limit of the admitted enterprises and lead brokers. If it identifies overruns, it notifies the management board without delay. If the risk amount overruns the security limit of an admitted enterprise or lead broker, this enterprise or lead broker shall furnish security in cash or as securities, acceptable to the management board, to Deutsche Börse AG in the amount defined by the management board. On the basis of the risk amount announced under section 16 (4) BörsO, all admitted enterprises and lead brokers shall notify the management board on each trading day of any overrun on the security limit by a deadline before start of trading, which has been fixed by the management board. The security furnished ensures that admitted enterprises and lead brokers meet the obligations they incur in their stock exchange trades. The Deutsche Börse AG administers the security furnished in accordance with these provisions. If the security already furnished does not cover the amount as fixed, the admitted enterprise or lead broker shall furnish the difference on any trading day by a deadline set by the management board.

Access to information

The ESA and the TSO have powers to request information of size and beneficial ownership if needed. Pursuant to Section 3 (4) no. 1 BörsG and Section 7 (3) BörsG, the ESA and the TSOs are authorized to require that trading participants disclose the identity of their customers and of the persons obligated under or entitled to the benefits of the executed transactions, as well as any changes in the trading participants' holdings of financial instruments which are traded on the exchange.

\section{Power to take appropriate action}

If a market participant does not provide the requested information to either the exchange or the TSO, the management board can initiate a Disciplinary Committee proceeding.

\section{Information sharing}

Domestic

The regulators are authorized to exchange information with other domestic regulators. Section 8 BörsG enables the ESAs to exchange information with each other and with BaFin. The TSOs are empowered to exchange information with each other (Section 7 (4) BörsG).

\section{Other jurisdictions}

The regulators are authorized to exchange information with other non-domestic regulators. The TSO is authorized to exchange data with TSOs of foreign exchanges and 
with other authorities which are responsible for monitoring trading on foreign exchanges. Data may only be transmitted to such authorities if they and the persons commissioned by them are bound by an obligation of confidentiality comparable to that set forth in Section 7 BörsG.

BaFin is empowered to exchange information with foreign authorities pursuant to section $7 \mathrm{WpHG}$.

\section{Default Procedures}

For Eurex, the general default circumstances are set out in section 4.7 BO Eurex (default occurs if a participant exceeds the position limits and is not able to reduce the position). For Frnakfurt Stock Exchange the general default circumstances are described in Section 29 BO FWB (default occurs if for any reason an entity or lead broker does not collateralize the reported total risk in time or does not timely fulfill any other provision according to the obligations under the rules).

The management board may take action as set out under Sections 29 to 33 BO FWB and Section 4.7 BO Eurex.

Section 28 BO FWB states that, if a company or lead broker does not meet its obligations from exchange trading in their entirety, the operator of the exchange shall, upon order of the management board, liquidate the margin provided by the company or lead broker in question

If the security required pursuant to exchange rules is not provided or is no longer available, a participant may:

a. be suspended for a maximum period of six months;

b. have its brokerage activities restricted; or

c. have its rights to enter into exchange transactions suspended for as long as the admission of the enterprise for which such person enters into transactions is suspended.

If an admitted enterprise or lead broker defaults, the management board may adopt measures pursuant to sections 21 to 24 FWB BO (increase in the risk amount; completion of pending trades; restriction to brokerage operation; suspension of admission; suspension of admission to stock exchange trading; withdrawal of entitlement to take part in block trading). Default occurs if an admitted enterprise or lead broker does not post defined security in time or does not timely fulfill any other provision according to the obligations under the present rules. Hence it is immaterial if there is lack of culpability on the part of the admitted enterprise or lead broker.

Each admitted enterprise and each lead broker shall notify the management board without delay if it cannot meet obligations from stock exchange trades, security postings or other obligations existing pursuant to the present rules.

Admitted enterprises and lead brokers are to receive a hearing from the management board before any measure under Sections 21 to 24 FWB BO is adopted. A hearing may be dispensed with if the circumstances do not warrant it (section 30 (2) FWB BO).

The management board may disclose to other trading participants the measures it has taken pursuant to Sections 21 to 24 FWB BO insofar as this does not conflict with the overriding interests of the enterprise or lead broker concerned which warrant protection 


\begin{tabular}{|l|l|}
\hline & $\begin{array}{l}\text { (Section 30 (3) FWB BO). } \\
\text { Reference is also made to the Settlement Finality Directive }{ }^{23} \text { which has been transposed } \\
\text { into national law in the relevant provisions of the KWG and the InsO. } \\
\text { Consultation between market authorities } \\
\text { The market authorities can consult with each other. The general rules on information } \\
\text { exchange apply. }\end{array}$ \\
\hline Assessment & Fully implemented \\
\hline Comments & \\
\hline Principle 30. & $\begin{array}{l}\text { Systems for clearing and settlement of securities transactions should be subject to } \\
\text { regulatory oversight, and designed to ensure that they are fair, effective and efficient and } \\
\text { that they reduce systemic risk. }\end{array}$ \\
\hline Description & Assessed as part of assessment of CPSS-IOSCO standards. \\
\hline Assessment & \multicolumn{2}{|c|}{} \\
\hline Comments & \\
\hline
\end{tabular}

\footnotetext{
${ }^{23}$ Directive 98/26/EC of the European Parliament and of the Council of 19 May 1998 on settlement finality in payment and securities settlement systems
} 


\section{APPENDiX I. NeW IOSCO PRINCIPLES}

41. In June 2010, IOSCO reviewed its Principles; 9 new Principles were added and one Principle removed (Principle 6). IOSCO is currently developing a revised Methodology, which will put in place criteria for the assessment of these new Principles. Until the methodology is in place the new Principles are not assessed. However, a short discussion on the new Principles was held on the "state of readiness" to implement these Principles when they come into effect. A summary of each is below.

Systemic risk monitoring and perimeter of regulation

New Principle 6: The Regulator should have or contribute to a process to monitor, mitigate and manage systemic risk, appropriate to its mandate.

New Principle 7: The Regulator should have or contribute to a process to review the perimeter of regulation, appropriate to regularly.

42. Existing structures and practices in BaFin support a focus on systemic risk.

43. Within the Directorate responsible for cross-sector issues there is a risk and financial markets analysis department, with organizational units dealing with separate aspects of financial market stability and market developments (financial stability, risk analysis, financial instruments, basic issues relating to accounting and auditing, and the real economy and effects on the financial sector). Other directorates (banking, insurance and securities) also conduct sector-based research.

44. Two years ago, BaFin established an organization-wide risk committee with representatives from all sectors, including insurance and supervision.

45. In addition, a new risk committee was formed in late 2010 to focus on the nonbank components of the securities industry, such as hedge funds. The committee has representatives from each department in the Securities Directorate (investment management, intermediaries etc). Its function is to channel information from the banking and insurance area to the relevant parts of the Securities Directorate, and from the Securities Directorate to other areas of BaFin.

46. BaFin reports regularly to the BMF on issues relating to the regulation of financial markets, and on occasion produces special reports on particular aspects. For example, in 2009 BaFin reported to BMF on problems in the regulation of the "grey" capital market, and suggested the need for more stringent regulation. 


\section{Securitization}

New Principle 8: The Regulator should seek to ensure that conflicts of interest and misalignment of incentives are avoided, eliminated, disclosed or otherwise managed.

47. Criteria for this Principle have yet to be developed but are expected to focus on conflicts of interest arising in securitization. Securitization was therefore the focus of discussion with the BaFin.

48. The regulation of securitization is implemented on an EU-wide basis. The EU has taken the view that conflicts of interest should be addressed via obligations for investors (rather than issuers/originators). Regulation includes conflicts of interest provisions in CRD (banks), Solvency II (insurers), and AIFM (fund managers) and through central bank initiatives. As these are the major investor groups, the rules developed will apply to all securitizations in the EU. Meanwhile, detailed conflict rules for licensed market intermediaries are in force (see under Principle 23 and the material referred to there).

49. In January 2011, a new legislative framework for securitization came into effect in Germany. For new securitizations conducted after January 1, 2011 this framework introduced:

- $\quad$ a 5 percent retention rule: a credit institution may only be exposed to the credit risk of a securitization position if the originator, sponsor or original lender of the securitization has explicitly disclosed that it will maintain a net economic interest in the securitization on an ongoing basis of not less than 5 percent. The minimum retention level will increase to 10 percent in 2015; and

- disclosure rules for sponsors and originators of securitizations: : next to their level of retention sponsors and originators have to disclose all materially relevant data on the credit quality and performance of individual underlying exposures, cash flows and collateral supporting a securitization exposure; disclosure must also comprise information necessary to perform comprehensive and well informed stress tests on the cash flows and collateral values supporting the underlying exposures.

50. Furthermore, the new regulation requires investors to be able to demonstrate that they have a comprehensive and thorough understanding of their investments in securitized positions. This enables them to analyze (i) all relevant information such as the risk characteristics of the securitized positions and the underlying exposures; (ii) the reputation and loss experience in earlier transactions of the originators or sponsors; and (iii) the disclosures made by the originators or sponsors, or their agents or advisers regarding their due diligence on the securitized exposures and the quality of the collateral (if applicable). Banks investing in securitizations also have to implement formal policies and procedures to record, analyze, and monitor relevant information including prepayment rates 
and default rates of the exposures underlying the securitized positions. Additional investors' duties comprise the performance of own stress tests and a thorough understanding of all structural features of a securitization, which have a material impact on their exposures such as the contractual waterfall, waterfall-related triggers, credit enhancements, and liquidity enhancements. Investors have to notify any breach of the requirements to the competent authorities. If they do not meet their duties in any material respect, the authorities will impose a risk weight that is at least 3.5 times higher than the risk weight which would regularly apply to this securitized position (maximum 1250 percent). In case of subsequent infringements the risk weight will be progressively increased by the competent authorities.

51. Originators and sponsors have to apply the same sound and well-defined criteria for credit-granting and the same processes for amending, renewing, and refinancing credits to exposures to be securitized as they apply to exposures to be held on their book. Originators not complying with this provision are not allowed to exclude the securitized exposures from the calculation of their capital requirements.

52. In case of a material breach of the disclosure requirements mentioned under point $b$., the competent authorities impose an increased risk weight that is at least 3.5 times higher than the risk weight regularly applied to the retention exposure held by the sponsor or originator (maximum 1250 percent).

53. The compliance with the new German regulation will be part of the banks' annual audit. In addition to the new law, German securitization transactions usually consist of credits from the bank balance sheet, meaning that they have gone through a credit origination process, where the sales force does not know which credit is going to be securitized later on.

\section{Assessment of conflicts of interest and misalignment of incentives are part of} ongoing supervision of regulated entities. This is done through regular contact by BaFin with the regulated entity (by supervisory interviews and participation in the auditors' on-site examination), analysis of auditors' reports (reports according to the Banking Act in conjunction with Deutsche Bundesbank), request for information and relevant documents as well as exchange of information on ongoing supervision in national and international bodies. BaFin has adopted and published a Circular on the Minimum Requirements for the Compliance Function and Additional Requirements Governing Rules of Conduct, Organisation and Transparency pursuant to Sections 31 et seq. of the Securities Trading Act (Wertpapierhandelsgesetz - WpHG) for Investment Services Enterprises (Mindestanforderungen an die Compliance-Funktion und die weiteren Verhaltens-, Organisations- und Transparenzpflichten nach $\S \S 31$ ff. WpHG für Wertpapierdienstleistungsunternehmen - MaComp). This Circular strengthens the compliance function in regulated entities, promoting sufficient measures to detect and resolve conflicts of interest. Also, recent legislative actions target the adequate assessment and resolution of conflicts of interest: minutes need to be written down when investment advice is given, a register for 
investment advisors is in place as well as the so called "key investor document" pursuant to the Securities Trading Act (Produktinformationsblatt) which will be mandatory from July, 1 2011. BaFin acts actively and preventive in the scope of its delegated power. With regard to the new key investment documents, for example, a market survey will take place in summer to assess the quality and comparability of this information.

\section{Auditor oversight}

New Principle 19: Auditors should be subject to adequate levels of oversight New Principle 20: Auditors should be independent of the issuing entity that they audit. New Principle 21: Audit standards should be of a high and internationally acceptable quality

55. The new Principles expand on Principle 16, accounting and auditing standards, and reflect some of the detailed work IOSCO has done on oversight of auditors and auditor independence. The assessment found full compliance with Principle 16.

56. Auditors are subject to a system of public oversight by:

- $\quad$ requiring auditors to be subject supervision by the Chamber of Auditors (Wirtschaftsprüferkammer, WPK). WPK is a professional body with public law responsibilities. It conducts examinations and reviews of audits and auditors. Auditors are required by legislation to submit to peer reviews and are subject to monitoring and disciplinary action by WPK.

- making the Auditor Oversight Commission (Abschlussprüferaufsichtskommission, APAK) responsible for supervision of the WPK, including its oversight and disciplinary activities. APAK's most senior roles are held by independent people who are not current members of the audit profession. APAK operates according to published rules of procedure approved by the Federal Ministry of Economics and Labor. The APAK is also responsible for cross-border co-operation concerning statutory auditor.

57. Independence standards are specified in the Commercial Code. They include a requirement for auditor rotation after 7 years. The Banking Act also allows BaFin to require the rotation of an audit partner or at any time.

58. The Commercial Code provides that audit standards adopted by the European Commission apply to statutory audits (such as those for listed issuers). To date there are no such standards and the audit standards in use are those issued by the Institute of Auditors (Institut der Wirtschaftsprüfer in Deutschland e.V., IDW).

59. Audit standards are largely in line with international audit standards (ISAs). 


\section{Credit rating agencies}

New Principle 22: Credit rating agencies should be subject to adequate levels of oversight. The regulatory system should ensure that credit rating agencies whose ratings are used for regulatory purposes are subject to registration and ongoing supervision

60. A comparatively large number of locally based CRAs (8), as well the three global CRAs are active in Germany.

61. Regulation of CRAs is set at the EU level and there is no separate German national regime. The relevant European Regulation (EC 1060/2009) provides a comprehensive set of rules regarding conflicts of interest, procedures, internal organization, transparency and the presentation of ratings. This framework reflects the IOSCO code of conduct for CRAs.

62. Current oversight of CRAs is based on an integrated oversight model involving supervisory colleges. These colleges deal with the "Big 3" CRAs and consist of 10-15 authorities and deal with applications for registration and taking supervisory measures. Applications require a unanimous decision, but current applications have not yet reached the decision stage.

63. A specialist team within BaFin is examining applications for locally based CRAs and working with the existing colleges.

64. From mid 2011 the European Securities and Markets Authority (ESMA) will assume responsibility for CRA regulation. Future assessments will have to determine whether ESMA, rather than the any national regulator, is adequately fulfilling this function.

65. Under the European Regulation credit rating agencies are required to declare if they adhere to any Code of Conducts, including the IOSCO Code of Conduct. While not obliged to adhere to the IOSCO Code of Conduct, the conditions within the Regulation mirror that of the IOSCO Code of Conduct. Specifically:

\section{Independence and avoidance of conflicts of interest}

66. The Regulation requires sound internal controls and sound reporting lines, clearly separating the rating function from business incentives. External surveillance is strengthened by internal discipline by giving the independent, non-executive members of the administrative or supervisory board of the credit rating agency specific tasks to ensure efficient control (Article 5 and Annex I, Section A, Point 2).

67. To ensure the independence of ratings, credit rating agencies are required to prevent conflicts of interest and/or to manage these conflicts adequately where they are unavoidable. They must disclose conflicts of interest in a complete, timely, clear, concise, 
specific and prominent manner and record all significant threats to the rating agency's independence or that of its employees involved in the credit rating process, together with the safeguards applied to mitigate those threats. They must limit their activity to credit rating and related operations, excluding consultancy or advisory services (Article 5 and Annex I, Section B).

68. CRAs must have adequate internal policies and procedures to insulate employees involved in credit rating from conflicts of interest and ensure the quality, integrity and thoroughness of the rating and review process at all times. Linked to this, agencies must allocate sufficient employees with appropriate knowledge and experience to their credit rating activity and make appropriate rotation arrangements for analysts and persons approving credit ratings. (Article 6 and Annex I, Section C).

69. The compensation arrangements of employees involved in the rating process must be determined primarily by the quality, accuracy, thoroughness and integrity of their work (Article 6(6)).

\section{Disclosure}

70. Under the Regulation CRAs are obliged to disclose ratings on a non-selective basis and in a timely manner, unless the ratings are only distributed by subscription. CRAs have to distinguish between ratings for structured products and for traditional products (corporate, sovereign) by the use of a different rating category for structured finance instruments or the provision of additional information on their risk characteristics. Specific disclosure requirements apply to unsolicited credit ratings (Article 8).

71. To ensure that internal processes and procedures are sufficiently transparent, credit rating agencies must publicly disclose some important information, e.g., on conflicts of interest, methodologies and key rating assumptions and the general nature of their compensation policy. They must also periodically disclose data on the historical default rates of rating categories and give competent authorities certain elements such as the list of the largest 20 clients by revenue (Article 9 and Annex I, Section E).

72. To ensure that relevant, standardised data on credit rating agencies' performance is available to allow market participants to make industry-wide comparisons, CESR is to create a publicly available central repository for such data (Article 9(2)). To restore public confidence in the rating business, credit rating agencies must publish an annual transparency report (Article 10 and Annex I, Section E, Part III), and keep records of their activities (Articles 5-7 and Annex I, Section B, Points 7-9).

\section{Confidential Information}

73. Credit rating agencies shall ensure that employees directly involved in the credit rating process: 
- $\quad$ take all reasonable measures to protect property and records in possession of the credit rating agency from fraud, theft or misuse;

- do not disclose any information about credit ratings or possible future credit ratings of the credit rating agency, except to the rated entity or its related third party;

- do not share confidential information entrusted to the credit rating agency with employees of any person directly or indirectly linked to it by control; and

- do not use or share confidential information for the purpose of trading financial instruments, or for any other purpose except the conduct of the business of credit rating agency.

\section{Analysts}

Principle 23: Other entities that offer investors analytical or evaluative services should be subject to oversight and regulation appropriate to the impact their activities have on the market or the degree to which the regulatory system relies on them.

\section{In Germany, round 400 licensed banks and financial services institutions} provide forward looking analysis to their clients. In addition, about 150 "independent analysts" provide these services.

75. For licensed firms, research activities from part of the regulated activities supervised by BaFin. These activities are subject the relevant requirements of MiFID and the Market Abuse Directive (MAD). BaFin undertook thematic work on research activities in 2010 by focusing on conflicts of interest and the use of watch lists. BaFin will also deal with any complaints about analysis activity. Research activities are part of the risk analysis process within BaFin .

76. The independent analysts are not required to be licensed but they are subject to regulation:

- $\quad$ they must inform BaFin of their identity and planned activities, including the types of securities on which they will provide research (though BaFin approval is not required);

- $\quad$ MAD provisions apply;

- $\quad$ the same disclosure requirements as for analysts working for banks and financial service institutions (section $34 \mathrm{~b}$ Securities Trading Act); and

- $\quad$ broad provisions of the Commercial Code apply, including requirements as to conflicts of interest. 


\section{Hedge Funds}

Principle 28: Regulation should ensure that hedge funds and/or hedge fund managers/advisers are subject to appropriate oversight

77. Hedge funds are already subject to regulation in Germany under the regulation applying to collective investment schemes. They are subject to the same rules as apply to other collective investment schemes, and to additional rules that apply specifically to them. These rules are described in the detailed assessment under Principle 17 (see also Principle 10).

78. A basis distinction is made between single hedge funds and funds of hedge funds. Single hedge funds are subject to few investment restrictions but are not permitted to invest in commodities (other than precious metals) or real estate.

79. Among the hedge fund specific rules are:

- $\quad$ disclosure rules - the simplified prospectus rules do not apply to hedge funds; and hedge funds are subject to additional mandated disclosures;

- $\quad$ marketing rules - the legislation prohibits public marketing of hedge funds in Germany.

80. BaFin monitors hedge funds more closely than most other collective investment schemes, and in its risk classification hedge funds management is automatically considered high impact.

81. The European Directive on Alternative Investment Funds Managers (AIFM) was formally approved in late 2010. It is intended to come into force in early 2011 and be transposed into national law and applied by Member States by 2013.

82. BaFin does not anticipate any major changes will be required to the existing regime to comply with the new IOSCO Principle, or the European AIFM directive. 